BNL-77919-2007

FORMAL REPORT

\title{
LIFE CYCLE INVENTORY ANALYSIS IN THE Production of Metals used in Photovoltaics
}

\author{
Vasilis M. Fthenakis, Hyung Chul Kim and Wenming Wang
}

March 2007

\author{
Energy Sciences and Technology Department \\ Brookhaven National Laboratory \\ P.O. Box 5000 \\ Upton, NY 11973-5000 \\ www.bnl.gov
}

\begin{abstract}
Notice: This manuscript has been authored by employees of Brookhaven Science Associates, LLC under Contract No. DE-AC02-98CH10886 with the U.S. Department of Energy. The publisher by accepting the manuscript for publication acknowledges that the United States Government retains a non-exclusive, paid-up, irrevocable, world-wide license to publish or reproduce the published form of this manuscript, or allow others to do so, for United States Government purposes.
\end{abstract}




\section{DISCLAIMER}

This report was prepared as an account of work sponsored by an agency of the United States Government. Neither the United States Government nor any agency thereof, nor any of their employees, nor any of their contractors, subcontractors, or their employees, makes any warranty, express or implied, or assumes any legal liability or responsibility for the accuracy, completeness, or any third party's use or the results of such use of any information, apparatus, product, or process disclosed, or represents that its use would not infringe privately owned rights. Reference herein to any specific commercial product, process, or service by trade name, trademark, manufacturer, or otherwise, does not necessarily constitute or imply its endorsement, recommendation, or favoring by the United States Government or any agency thereof or its contractors or subcontractors. The views and opinions of authors expressed herein do not necessarily state or reflect those of the United States Government or any agency thereof. 


\title{
Life CyCle InVEntory AnAlysis in the Production of
}

\section{Metals used in Photovoltaics}

\author{
Vasilis M. Fthenakis, Hyung Chul Kim and Wenming Wang
}

March 30, 2007

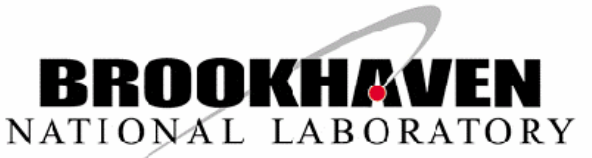

Energy Sciences and Technology Department

Brookhaven National Laboratory

Brookhaven Science Associates

Upton, Long Island New York 11973

Under Contract No. DE-AC02-98CH10886 with the

UNITED STATES DEPARTMENT OF ENERGY 


\section{Life CyCle InVEntory Analysis in the Production of Metals used in Photovoltaics}

Vasilis M. Fthenakis, Hyung Chul Kim and Wenming Wang

March 30, 2007

BRDDKHAIEN
NATIONAL LABORATORY

Energy Sciences and Technology Department

Brookhaven National Laboratory

Brookhaven Science Associates

Upton, Long Island New York 11973

Under Contract No. DE-AC02-98CH10886 with the

UNITED STATES DEPARTMENT OF ENERGY

National Photovoltaic EHS Research Center

Brookhaven National Laboratory

Upton, NY 11973 


\title{
ACKNOWLEDGEMENTS
}

This work was supported by the Photovoltaic Energy Technology Division, Conservation and Renewable Energy, under Contract DE-AC01-76CH00016 with the US Department of Energy. The authors thank J. Rannels and R. Sutula, DOE, for their support and encouragement, and J. Ermer, Spectrolab, J. Geisz, NREL, and J. Mazer, DOE, for their comprehensive reviews of this document.

\begin{abstract}
Material flows and emissions in all the stages of production of zinc, copper, aluminum, cadmium, indium, germanium, gallium, selenium, tellurium, and molybdenum were investigated. These metals are used selectively in the manufacture of solar cells, and emission and energy factors in their production are used in the Life Cycle Analysis (LCA) of photovoltaics. Significant changes have occurred in the production and associated emissions for these metals over the last 10 years, which are not described in the LCA databases. Furthermore, emission and energy factors for several of the by-products of the base metal production were lacking. This report aims in updating the life-cycle inventories associated with the production of the base metals $(\mathrm{Zn}, \mathrm{Cu}, \mathrm{Al}, \mathrm{Mo})$ and in defining the emission and energy allocations for the minor metals (Cd, In, Ge, Se, Te and Ga) used in photovoltaics.
\end{abstract}

Key words: Photovoltaics, Life Cycle Analysis, Materials Inventory Analysis, CdTe, CIGS, Emissions, Metal production, Selenium, Tellurium, Indium, Germanium 


\section{Contents}

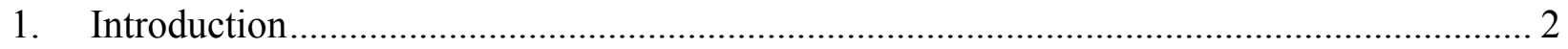

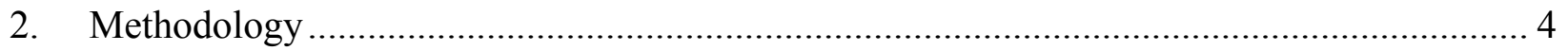

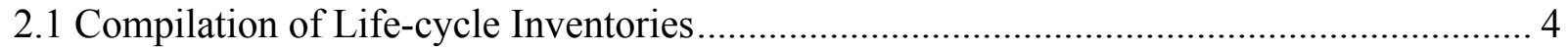

2.2 Allocation of Emissions .............................................................................................. 4

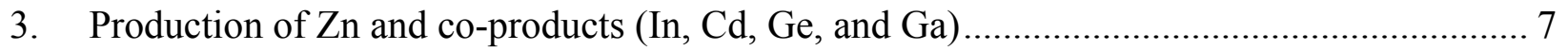

3.1 Ore Composition, Mining and Beneficiation............................................................. 7

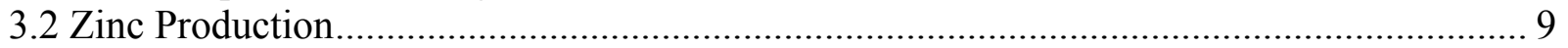

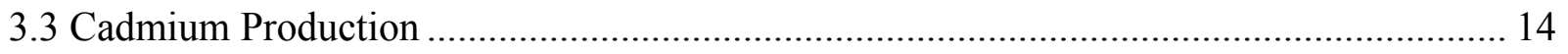

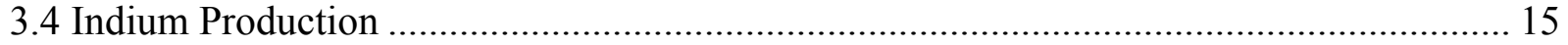

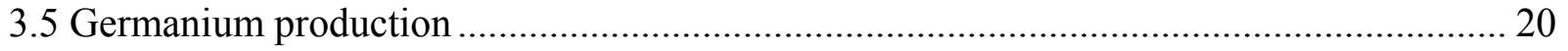

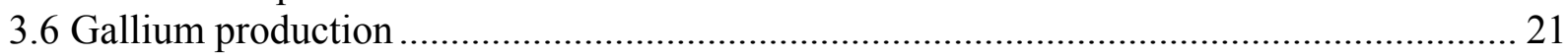

3.7 Purification of Cd, In, Ge and Ga for PV production .................................................... 23

3.8 Energy Factors in the co-production of Zn, Cd, In, Ge and Ga....................................... 29

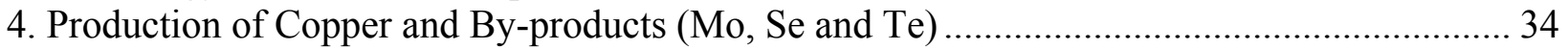

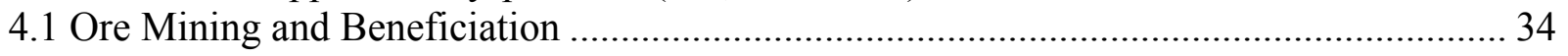

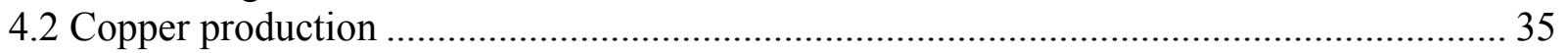

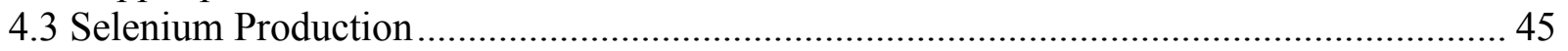

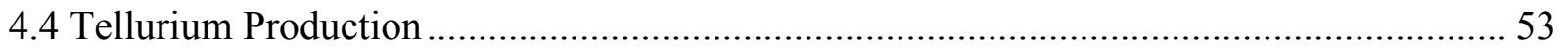

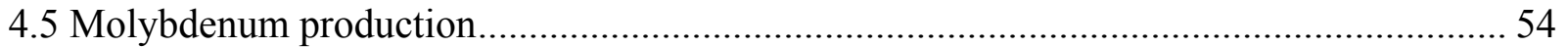

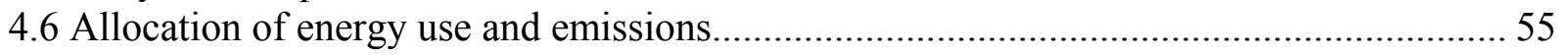

4.7 Emission Factors in the co-production of $\mathrm{Cu}, \mathrm{Mo}$, Se and Te......................................... 55

4.8 Energy Factors in the production of copper and by-products............................................. 69

5. Primary Production of Molybdenum ……………....................................................... 72

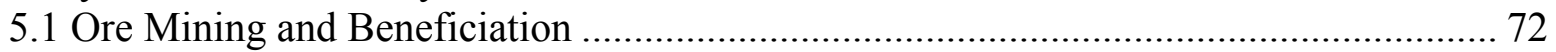

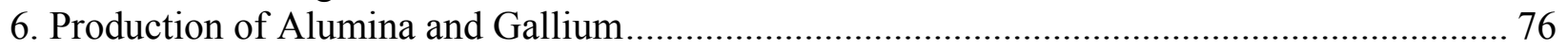

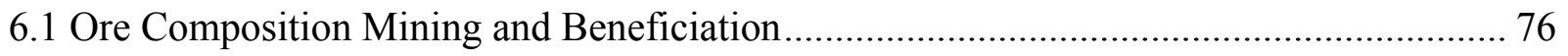

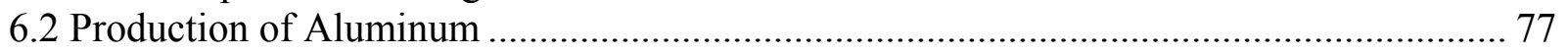

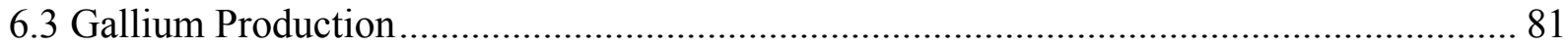

6.4 Emission factors in the co-production of aluminum and gallium:...................................... 89

6.5 Energy factors in the production of Aluminum and by-Products ...................................... 94

7. Current Trends and Future Outlook in the Production of Metals ................................................ 96

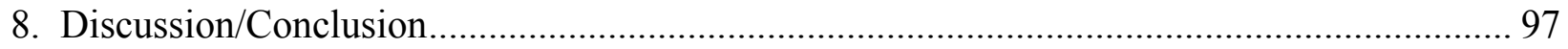




\section{Introduction}

There is a need for up-to-date estimates on the emissions during the production of the constituents of photovoltaic (PV) modules, because such data are used to derive important conclusions regarding the environmental impacts of PV technologies. Significant changes have occurred in the emission factors associated with producing the metals used for semiconductors, coatings, and frames in PV modules. Emissions from smelters were greatly reduced over the last ten years as companies strove to improve their environmental records. However, the databases used for Life Cycle Analysis (LCA) models often are outdated. A cursory review of the major LCA databases, EcoInvent (Swiss Centre for Life Cycle Inventory) ${ }^{1}, \mathrm{ETH}^{2}{ }^{2}$ DEAM (TEAM) ${ }^{3}$, and IVAM4 ${ }^{4}$ (University of Amsterdam), revealed some emission factors based on outdated information from 1980, with most sources dating before the mid 1990s. In addition, the "minor" metals ( $\mathrm{Cd}, \mathrm{Se}, \mathrm{Te}, \mathrm{In}, \mathrm{Ga}$ and $\mathrm{Ge})$ that are by-products of base metal smelting (e.g., $\mathrm{Cu}, \mathrm{Zn}, \mathrm{Pb}$, $\mathrm{Al}$ ), either are not included or are inadequately described. Among them, only cadmium is included in DEAM, only Se and Mo are included in EcoInvent, and IVAM4 has none. The emission factors for $\mathrm{Cd}$ in DEAM are the same with those for $\mathrm{Zn}$ although there are clear rules

\footnotetext{
${ }^{1}$ Althaus H.-J., Blaser S., Classen M., Jungbluth N. (2003) Life Cycle Inventories of Metals. Final report ecoinvent 2000. Editors: 0. Volume: 10. Swiss Centre for LCI, EMPA-DU. Dübendorf, CH.
}

2 Frischknecht R, Hofstetter P, Knoepfel I, Ménard M, Dones R, Zollinger E. Öko-inventare von Energiesystemen. ETH-ESU. Zürich, Switzerland, 1996.

${ }^{3}$ Ecobilan. (2001). “TEAM/DEAM.” Ecobilan, PriceWaterhouseCoopers, Rockville, Md.

${ }^{4}$ Lindeijer E. and Ewinjk H., IVAM LCA Data 2.0, IVAM Environmental Research, Amsterdam, The Netherlands, 1998. 
(e.g., ISO 14001) for avoiding allocation in the co-production of metals by dividing the process into distinct sub-processes.

This paper describes materials' environmental inventory analyses which are the first step in the life cycle analyses of solar cells. CIGS solar cells, use $\mathrm{Zn}, \mathrm{Cu}$, In, Ga, Se, Cd, and Mo. CdTe cells use $\mathrm{Cd}, \mathrm{Cu}$ and Te. Some amorphous $\mathrm{Si}$ solar cells use $\mathrm{GeH}_{4}$ and Ag. Some crystalline $\mathrm{Si}$ cells use $\mathrm{Pb}$ in solder. Some modules have $\mathrm{Al}$ frames. From these metals, $\mathrm{Cu}, \mathrm{Zn}, \mathrm{Pb}$ and $\mathrm{Al}$ are primary (base) metals, which are extracted in large quantities for their value, whereas $\mathrm{In}, \mathrm{Ga}, \mathrm{Se}$, $\mathrm{Cd}, \mathrm{Mo}, \mathrm{Ge}$ and Te are minor metals generated as by-products of the production of the base metals.

In, $\mathrm{Cd}, \mathrm{Ge}$, and to small degree $\mathrm{Ga}$ are by-products of zinc production; most $\mathrm{Ga}$ is produced as a by-product of aluminum production. Some $\mathrm{Cd}$ is also produced in lead production. Se and $\mathrm{Te}$ are by-products of copper production.

Emissions from the non-ferrous metal industry were reported as the largest contributor to global emissions of As, $\mathrm{Cd}, \mathrm{Cr}, \mathrm{Cu}, \mathrm{In}, \mathrm{Mn}$, and $\mathrm{Zn}$ in 1983 [1]. These emissions were debated by others [2] and the quality of various estimates was questioned. In more recent studies, Pacyna and Pacyna have compiled emissions from several regions of the world, based on both estimates and actual measurements (i.e., emission inventories); the most recent paper by these authors shows 1995 emission factors in comparison to those in 1983 [3]. According to these investigators emissions of trace metals have in average decreased during these 12 years by a factor of 2 to 3 , mostly because of better emission controls in major smelters in Europe and North America. Comprehensive emission factors more recent than 1995 are not reported in the literature. Also, emission factors for the production of the minor metals are not reported. 
Our study reviews the most current emission and energy data and examines the trends in the production of each of the four base metals and by-products. The production processes are described in a detail, which is sufficient for allocating emissions among the base metal and the minor metals. Emission factors for the four primary metal categories are reviewed and updated based on plant-specific information for plants in the US and Canada. Also European and global trends are discussed.

\section{Methodology}

\subsection{Allocation of Emissions}

The problem of allocation in Life Cycle Assessment for joint production is a fundamental one [4]. The International Standard Organization (ISO) specifies a procedure (ISO 14041) for deciding such allocation [5]. It entails the following steps: 1) Allocation should be avoided, whenever possible, by dividing the process into sub-processes, and including the additional functions related to co-products. 2) Where allocation cannot be avoided, the system's inputs and outputs should be partitioned to reflect the underlying physical relationships between them (i.e., they must mirror the way the inputs and outputs are altered by quantitative changes in the products or functions). 3) Where physical relationships alone cannot be established or used as a basis for allocation, inputs should be allocated between the products in proportion to the products' economic values.

According to the first rule of the ISO 14041, the emissions from the mining of the zinc ores to the recovery of saleable zinc are allocated to zinc and the emissions during the purification of the waste stream to extract a by-product, are assigned to the byproduct. 
For $\mathrm{Cd}$, the case for avoiding co-allocation of energy and emissions between $\mathrm{Zn}$ and $\mathrm{Cd}$ is clear because $\mathrm{Cd}$ is an unavoidable byproduct of $\mathrm{Zn}$ production. A few European smelters are stabilizing and storing this material in managed repositories, but most $\mathrm{Zn}$ smelters produce $\mathrm{Cd}$ metal as an unavoidable byproduct since it is present in the zinc concentrate feed to the smelter. The production of zinc alone determines the amount of cadmium produced; demand for it has zero effect on the quantity of cadmium generated. The production of cadmium metal from the $\mathrm{Cd} / \mathrm{Cu}$ cement is clearly a distinct process. Also purification of $\mathrm{Cd}$, for example by distillation, should result in energy and emissions, which are totally attributed to Cd. Thus, the zinc cycle starts with mining the $\mathrm{Zn}$ ores and ends with generating the saleable $\mathrm{Zn}$ product, whereas the cadmium cycle starts with the $\mathrm{Cd} / \mathrm{Cu}$ cement, and includes the steps related to the separation and purification of cadmium. This avoidance of allocation is in agreement with well-accepted LCA practices [7].

Also, indium and germanium are along for the ride until the oxide leach plant when they are separated from the $\mathrm{Zn} / \mathrm{Pb}$ fume. In the case of germanium, operation with high concentrations can be problematic because the Ge can break through the iron purification process, contaminating the purified electrolyte and preventing effective electrowinning of the contained Zn. Cd, In and Ge are typically referenced as "impurities" on the zinc production (Groot and Verhelst, 2000) $)^{5}$. Therefore, the energy input into the overall production processes should be allocated to the production of zinc, and not of the by-products, until the point that the In and Ge rich residue is deliberately processed for In and Ge production. Despite the small and highly cyclic market for In and Ge, smelters that pyrometallurgically treat their residues will continue to produce In and Ge products since the marginal cost of production, due to operation of the In and

\footnotetext{
${ }^{5}$ Groot E.T. and Verhelst D.L., Cominco's Trail Operations: An Integrated zinc-lead operation, Lead-Zinc 2000 (ed. Dutrizac et al.), TMS (The Mineral, Metal \& Materials Society, 2000, pp. 307-318.
} 
Ge refining steps, is usually small compared with the typical average sales price. The separation processes in the indium-germanium plant are distinct processes like the production of $\mathrm{Cd}$, and all the energy and emissions associated with this stage are attributed to the by-products.

$\mathrm{Ga}$ is typically recovered hydrometallurgically from the main leach circuit in an add-on step, so this too through to purification is a distinct process that should be accounted for separately. If the Ga were not recovered, it would be bound up in the residues and eventually leave the site in slag. Tellurium is a byproduct of copper production, and is also collected from waste streams. It is also present in $\mathrm{Zn}$ and $\mathrm{Pb}$ production, but it has to be to bleed out from these circuits as it ends up interfering with the recovery of silver and gold. These smelters, however, nay not have enough Te to justify building a Te refining process and they choose materials that do not contain $\mathrm{Te}$. Te is carried along up to the point where it is separated from the precious metals plant, in which case any emissions and energy use would be attributable to silver and gold production. The treatment of the Te soda slag and the recovery of the metal are clearly processes for $\mathrm{Te}$ production and are accounted separately.

The case of avoiding allocation among zinc and cadmium is stronger than that of the other byproducts because of its low value and strict limits in associated emissions or discharges. Recovery of low-value by-products from waste for use as industrial raw materials is referred as "waste mining" [6]. Assuming a fixed level of demand for the prime metal (copper or zinc), the choice is between leaving the minor metal in gangue, slag, or dust, or recovering it for use. Recovery is encouraged for precious metals (e.g., gold and silver) that have value, and their applications are environmentally harmless, but not for cadmium. However, the case with indium and tellurium, metals of low availability, is complicated by the lack of alternatives in today's market and the relatively high (although) highly erratic price they demand. For these minor 
metals, allocation was also examined as part of sensitivity analysis. We allocated emissions and energy use based on mass output according to the $2^{\text {nd }}$ step of the ISO guidelines, and also based on the economic value of the produced metals in accordance to the $3^{\text {rd }}$ step of the guidelines.

\section{Production of $\mathrm{Zn}$ and co-products (In, Cd, Ge, and Ga)}

\subsection{Ore Composition, Mining and Beneficiation}

Zinc is found in the earth's crust primarily as sphalerite, a mineral containing zinc sulfide (ZnS). Sphalerite ores contain $3 \%$ to $11 \%$ zinc, along with $0.0001 \%$ to $0.2 \%$ cadmium (median concentration $=220 \mu \mathrm{g} / \mathrm{g}),<0.0001 \%$ to $0.01 \%$ indium, copper, lead, silver and iron, and small amounts of gold, germanium and thallium. Indium also exists in the ores of other base metals (e.g., copper, lead, and tin), but most of these deposits are too dilute for indium recovery. Also some deposits of tin and tungsten carry relatively high concentrations of indium, but indium from this type of deposits is difficult to process economically.

The major phases of mining include: extraction (underground and open pit) and ore beneficiation (i.e., concentration). In underground mines, the ore is excavated by drilling machines, processed through a primary crusher, and then conveyed to the surface. In open-pit mines, the ore is loosened and pulverized by explosives placed in drilled holes and is scooped up by mechanical equipment. The ores are then transported to a concentration mill, which is usually at the metallurgical part of the operation. Mining generates large volumes of solid waste since the mining operation necessarily involves the removal of waster rock (gangue) in addition to the ore. The waste-to-ore ratio from underground minining is typically 0.2 to 1 , whereas this ratio for surface mining ranges from 2:1 to 8:1. Zinc and lead ores are mined almost exclusively in underground operations $[8]$. 
The concentration of the metals in the recovered ore is done by crushing, grinding, screen separation, and flotation processes. Crushers, screens, and rod- and ball-mills reduce the ore to powder of 20-200 $\mu \mathrm{m}$ sizes. The particles are separated from the gangue and concentrated in a liquid medium by gravitation or by selective flotation, followed by cleaning, thickening, and filtering [9]. The most common separation method is froth flotation in which the crushed ore is mixed with water, treated with suitable reagents and then frothed by blowing bubbles into the mixture. The metal concentrates are dewatered, dried, and shipped to smelter processing [10]. The zinc concentrates are transferred to smelters/refiners to produce the primary metals (Figure 1).

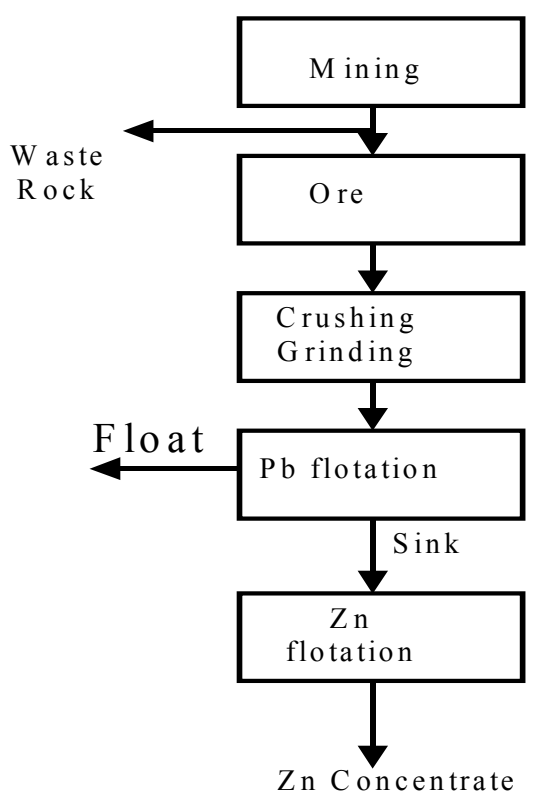

Figure 1. Cadmium flows in zinc mining 


\subsection{Zinc Production}

Zinc can be refined by either pyrometallurgical or hydrometallurgical treatment of its concentrates (Figure 2) [10]. Older roast/retort smelters are no longer employed in North America and Northern Europe. Globally, about $90 \%$ of the zinc production is done by the electrolytic process [13]. As of 2001, about $90 \%$ of the world's zinc production is done by the electrolytic process and about $8 \%$ by the Imperial Smelting process [13]. The trend towards electrolytic recovery continues and the last Imperial Smelter in England closed in 2003. The global demand for zinc is increasing and this growth is fueled by China, also the biggest producer, where the consumption of zinc increased by 10\% in 2004 (USGS, Aug 04); this country is also the biggest producer of zinc in the world.

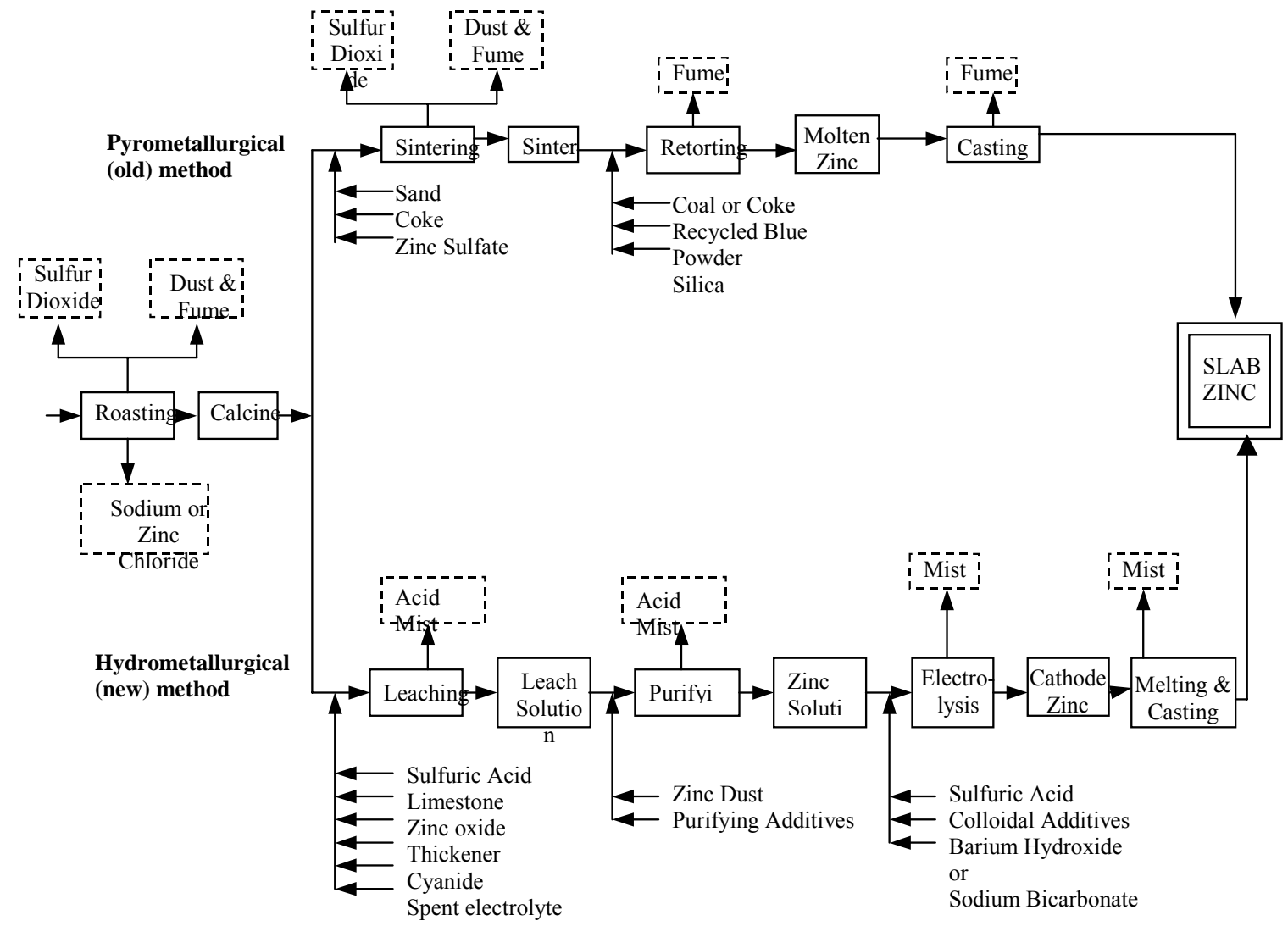

Figure 2. Generalized process flow for primary zinc smelting [11] 
There are four primary zinc-smelting operations in the United States. Three of them utilize electrolytic technology, and one uses an electrothermal process [10]. In Canada, there are four zinc producers, all of which use electrolytic processes for zinc refining. Canada is the second largest zinc producer in the world, after China. The total Canadian refined zinc production in 2002 was 793,000 metric tons (tonne) and that of the US was 289,000 tonnes. The zinc ore production from mines in the two countries was 916,000 and 783,000 tonnes of crude metal correspondingly (Zinc in Canada-Minerals and Metals). The US exports most of its mine production for processing in other countries. In addition to $\mathrm{Zn}$, the zinc smelters in North America also produce $100 \%$ of the $\mathrm{Cd}$, Ge, In, and Th, $10 \%$ of $\mathrm{Ga}, 6 \%$ of $\mathrm{Pb}, 4 \%$ of $\mathrm{Ag}$ and $3 \%$ of Au used in the region [12]. All the zinc smelters in North America also produce cadmium as an unavoidable by-product; before cadmium production started in the US in 1907 in the US, about $85 \%$ of the $\mathrm{Cd}$ content of the zinc concentrates was emitted to the environment during roasting and fractional distillation of zinc metal [15]. Indium and germanium are only produced in two Canadian facilities, the TeckCominco, Trail and the Falconbridge, Kidd Creek facilities. The electrolytic zinc process consists of five main operations, roasting, leaching, purification, electrodeposition and melting/casting (Figure 3). In some operations roasting and the first part of leaching are replaced by pressure leaching.

i) In roasting, the sulfide concentrates are fed to fluidized-bed furnaces where they are burnt with air and direct oxygen. Approximately one-half of the oxidized concentrate (zinc calcine) leaves the roasters in a melted phase by overflow and the rest is carried by the roaster gases. Zinc calcine, is mainly zinc oxide with small amounts of iron, cadmium, and other metals. Calcine is cooled, passed through a mill and collected in cyclones and electrostatic precipitators. The roaster gases, containing about $8 \%$ sulfur dioxide, are cooled in a waste- 
heat boiler, to recover heat and generate steam. They are usually treated to recover mercury, before they are fed into a sulfuric acid plant.

In alternative pressure leaching operations, the zinc concentrates are treated with acid and oxygen in vessels under $150{ }^{\circ} \mathrm{C}$ and $1400 \mathrm{kPa}$. Elemental sulfur is extracted in series of flotation cells and the slurry of zinc sulfate is pumped into the leaching plant for further processing.

ii) Leaching of the metals from the calcine is accomplished by sulfuric acid, which is typically produced from $\mathrm{SO}_{2}$ in house. This process dissolves the zinc to make a solution of zinc sulfate and other acid-soluble metals. Iron is precipitated and filtered from the process as a residue. Depending on the ore, the residue may also contain lead, copper, silver, and gold. Cadmium is not removed in the iron purification step, and must be removed by cementation with $\mathrm{Zn}$ metal powder to produce a $\mathrm{Cd} / \mathrm{Cu}$ cement. The leachate is sent to the purification section.

(iii) In purification, cadmium, germanium, indium, and gallium as well as iron, copper, cobalt and nickel are removed, usually in three stages. These are described in sections 3.3 to 3.6 below.

(iv) Zinc is recovered from the sulfate solution by electrodeposition on aluminum sheet cathodes. The Zn-covered cathodes are removed periodically and the pure zinc layer covering them is stripped off and fed into induction furnaces. Also sulfuric acid is regenated in this stage.

(v) The final steps in zinc production are melting, casting, and alloying. The zinc stripped off from the cathodes is melted, and cast into ingots, slabs, or larger blocks of slab ready for delivery to customers $[31,14]$. 


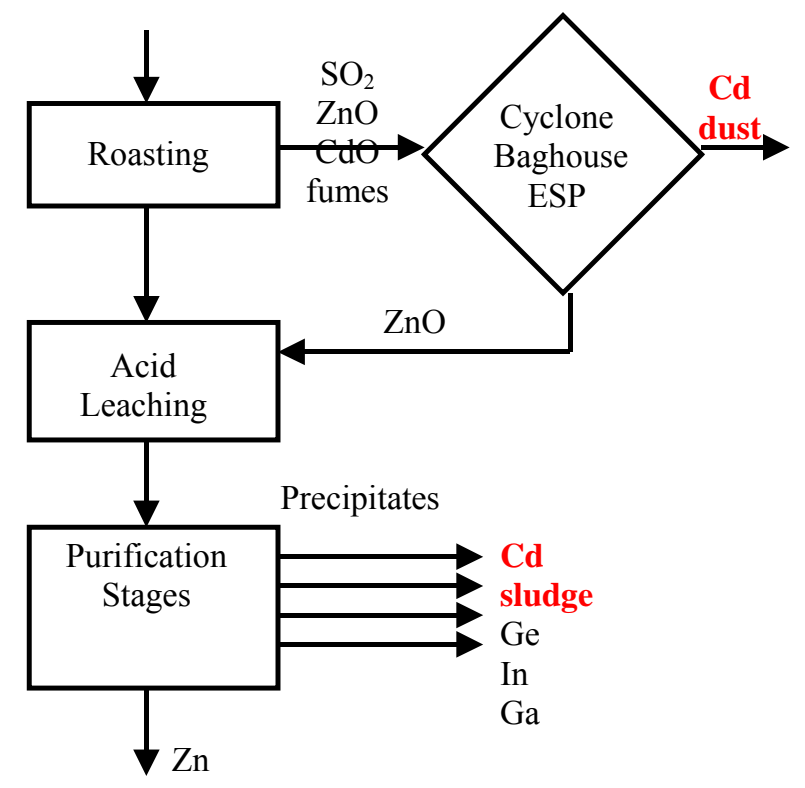

Figure 3. Cadmium flows in zinc reefing and by-product production

The Imperial Smelting process uses sintering and smelting instead of roasting and electrolytic recovery. The sintering process generates much higher air emissions than roasting as discussed in the emissions' session.

\section{Description of the Major Zinc Producers in Canada}

The four major zinc production facilities in Canada are:

a) Teck Cominco Ltd. With smelting facilities in Trail, Ontario, Canada, is one of the world's largest zinc smelters, producing $\sim 284,000$ tonne/yr of zinc), $\sim 88,000$ tonne/yr of lead), gold, indium, cadmium, germanium oxide, sulfuric acid, liquid $\mathrm{SO}_{3}$ and fertilizers.

b) The Canadian Electrolytic Zinc (CEZ) Ltd., another very large zinc producer, processes zinc concentrates produced by several mine-mill complex in Ontario and Québec. Its products include zinc ( 260,000 tonne/yr), cadmium, copper cake and sulfuric acid. Zinc and by-products are recovered from concentrates through fluidized roasting, sulfuric acid leaching, and electrowining. During fluidized roasting zinc sulfide oxidizes to zinc oxide. Off-gas is treated then sent to sulfuric acid plant for the recovery of sulfur dioxide. Then, the zinc calcine from the roaster is 
subject to sulfuric acid leaching to extract zinc and other metals. The leaching is a three-stage process. Both zinc and iron are leached into solution. The dissolved iron is removed with ammonia as ammonium jarosite. In a subsequent purification step, impurities are cemented with zinc dust. After purification, the zinc sulfate solution is subject to electrowinning to recover zinc as zinc cathode. The zinc cathode is melted and caste into slabs for shipment to customers. The spent electrolyte is reused in the leaching process.

c) The Falconbridge Limited's Kidd Creek operation in Timmins, Ontario produces zinc ( 140,000 tonne/yr), copper (132,000 tonne/yr), indium, cadmium, silver and sulfuric acid [19]. Zinc production uses both roasting-leaching-electrowinning and oxygen-pressure leachingelectrowinning. In the roasting-leaching-electrowinning process, two standard Lurgi fluid bed roasters are used to remove sulfur. The Acid Plant is a Monsanto single-absorption plant with a design conversion efficiency of approximately 98\%. The oxygen pressure leachingelectrowinning involves oxygen and high temperature in an autoclave to directly produce zinc sulfate from the zinc concentrate, thus eliminating the need for roasting. It is estimated that $80 \%$ of zinc is produced by the former process while $20 \%$ of zinc is produced by the later process at Kidd Creek. The copper smelter is based on the Mitsubishi process and consists of three furnaces (Smelting, Slag Cleaning, Converting). The Acid Plant is a double-contact, double absorption plant with a design conversion efficiency of $99.5 \%$. Approximately, $10 \%$ of the sulfur dioxide contained in the off-gas stream is recovered as liquid sulfur dioxide.

d) Hudson Bay Mining \& Smelting (HBMS) operates several underground mines and a smelter which produce zinc $(\sim 93,000$ tonne/yr), copper $(\sim 39,000$ tonne/yr), gold and some cadmium. They are located in Flin Flon Manitoba, Canada. Gold is a by-product from refining of copper anode. In the zinc plant, HBMS uses pressure leaching followed by electrowining fro the 
extraction of zinc. Prior to 1993, the zinc refinery was based on a roast-leach-electrowinning

process. Zinc concentrates are first subject to partially neutralized returned acid leaching, then to fresh acid leaching. After a two-stage pressure leaching, copper is removed by cementation with zinc. After purification, the liquor is subject to electrowinning to produce zinc cathodes. The copper plant uses the roasting-reverberatory-Peirce-Smith converter technology. Copper concentrate goes to a multiple hearth roasters, then to a reverberatory furnace through which the matte is generated. The matte is then treated in Peirce-Smith converters.

\subsection{Cadmium Production}

The feed material for producing cadmium consists mainly of residues from the electrolytic production of zinc, and of fume and dust collected in baghouses from emissions during pyrometallurgical processing of zinc and lead smelting.

The cadmium sponge, a purification product from precipitating zinc sulfate solution with zinc dust at the zinc smelter, is $99.5 \%$ pure cadmium. This sponge is transferred to a cadmium recovery facility and is oxidized in steam for two days or so. The product, cadmium oxide, along with particulates collected in baghouses ${ }^{6}$, is leached with spent cadmium electrolyte and sulfuric acid to produce a new recharged electrolyte. Impurities are precipitated with a strong oxidizing agent. The wastes are refined for other uses or stockpiled, until a use can be found for them. Non-corrosive anodes are used during electrowinning. Additives (often animal glue) are used to enhance the smoothness of the resulting cadmium cathode. The cathodes are removed about

\footnotetext{
${ }^{6}$ About $10 \%$ of cadmium is produced from the fumes and dusts of lead smelters. These are concentrated to $8 \%$ to $60 \% \mathrm{wt}$ cadmium and shipped to the cadmium recovery plant where they are reacted with sulfuric acid. The resulting calcined cadmium sulfate and impurities are roasted and then leached with water to dissolve the cadmium. The cadmium sulfate solution is first filtered to remove the lead sulfate, which is recycled to the lead smelter and then further purified by electrolytic separation. The resulting electrolyte is $99.995 \%$ pure. The cadmium is melted and cast into shapes. The spent electrolyte is recycled at the cadmium recovery plant.
} 
every 24 hours and are rinsed and stripped. The stripped cadmium is melted under flux or resin and cast into shapes.

In a slightly different route, purification residues from the oxide and the sulfide-leaching processes are further leached with sulfuric acid and filtered through three stages to remove zinc, copper, and thallium before recovering the dissolved cadmium. Cadmium can be further purified with vacuum distillation to $99.9999 \%$ purity [14].

The total loss in emissions and residues at cadmium plants is about $5 \%$ [15]. Thus, about $95 \%$ of Cd from Cd concentrates is converted in metallurgical grade (99.99\%) metal, which is used in all current applications, except for semiconductor CdTe and CdHgTe. High purity (i.e., 99.999\%99.9999\%) Cd powder is produced by electrolytic purification and subsequent melting and atomization or by vacuum-distillation followed by zone refining.

\subsection{Indium Production}

Indium is a metal with relatively low availability. It is recovered as a byproduct of zinc production from the fumes, dusts, slags, and residues in zinc smelting [16]. The total global production in 2003 was about 300 metric tons [17].

The four major indium-producing countries are Canada, China, France, and Japan. The associated quantities are shown in Figure 4. Indium is not recovered from ores in the United States. However, Indium Corporation of America, Utica, New York, and Arconium Specialty Alloys, Providence, Rhode Island produce indium metal and indium products by upgrading imported indium metal. Lower grade (99.97\%) and standard-grade (99.99\%) imported indium is refined to purities of up to $99.9999 \%$ in these facilities. 


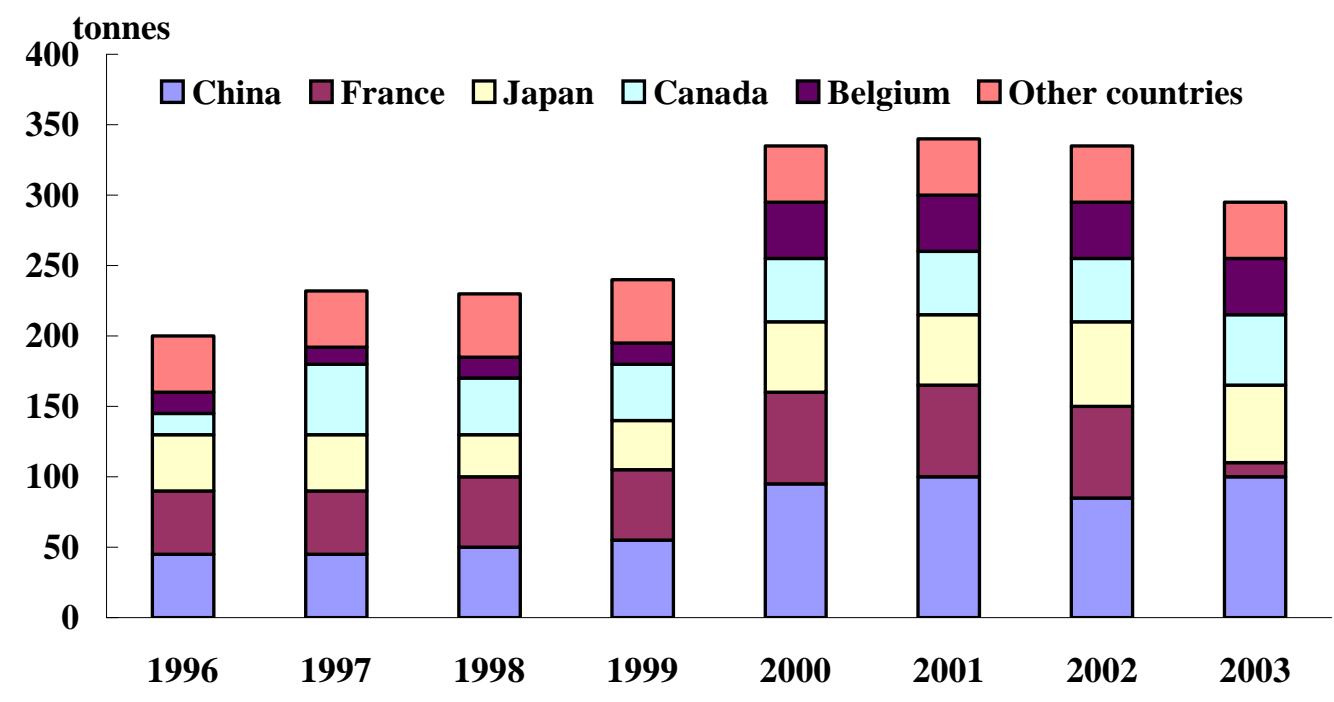

Figure 4. World Refined Indium Production, 1996-2003(Source: Based on the United States Geological Survey estimates) [17]

Two facilities in Canada recover indium: Teck Cominco's zinc-lead smelter at Trail, British Columbia, and Falconbridge's Kidd Creek copper-zinc smelter in Timmins, Ontario.

The information on In and Ge production is sketchy since a technology to recover them is proprietary, and large part of the production is from China. Below we list a description of such recovery from Ullmann's encyclopedia [18] and some general information from manufacturers' reports.

Following the zinc operations described in 3.2, after roasting, the zinc oxides undergo leaching and purification, which produces indium. Zinc oxide is first leached with dilute sulfuric acid to remove zinc, and the residue is leached again with dilute hydrochloric acid [18]. This leaching removes most of the lead and also, a small portion of indium and arsenic from the residues. The residue contains about $20 \%$ arsenic, 5 to $10 \%$ tin, $5 \%$ antimony, and $0.2 \%$ indium. In the next step, soda is added to the remaining filtrate to precipitate the majority of indium. This is the major stream in indium extraction. The concentration of metals in the filtrate are about 10-50 
$\mathrm{mg} / \mathrm{L}$ of indium, $40 \mathrm{~g} / \mathrm{L}$ of zinc, $6 \mathrm{~g} / \mathrm{L}$ of cadmium, and $1 \mathrm{~g} / \mathrm{L}$ of arsenic. About $10 \%$ of the indium remains in the residue, which is leached with sodium hydroxide to create crude indium hydroxide, containing $20 \%$ indium, $6 \%$ zinc, $1.5-3 \%$ arsenic, and $0.5-2 \%$ cadmium [18]. The crude indium hydroxide is leached with dilute hydrochloric acid. The indium solution is purified by cementation of copper and arsenic with iron, followed by cementation of tin and lead with indium [18]. Finally, to remove the indium, aluminum is added to create indium cement. This sequence is shown in Figure 5. 


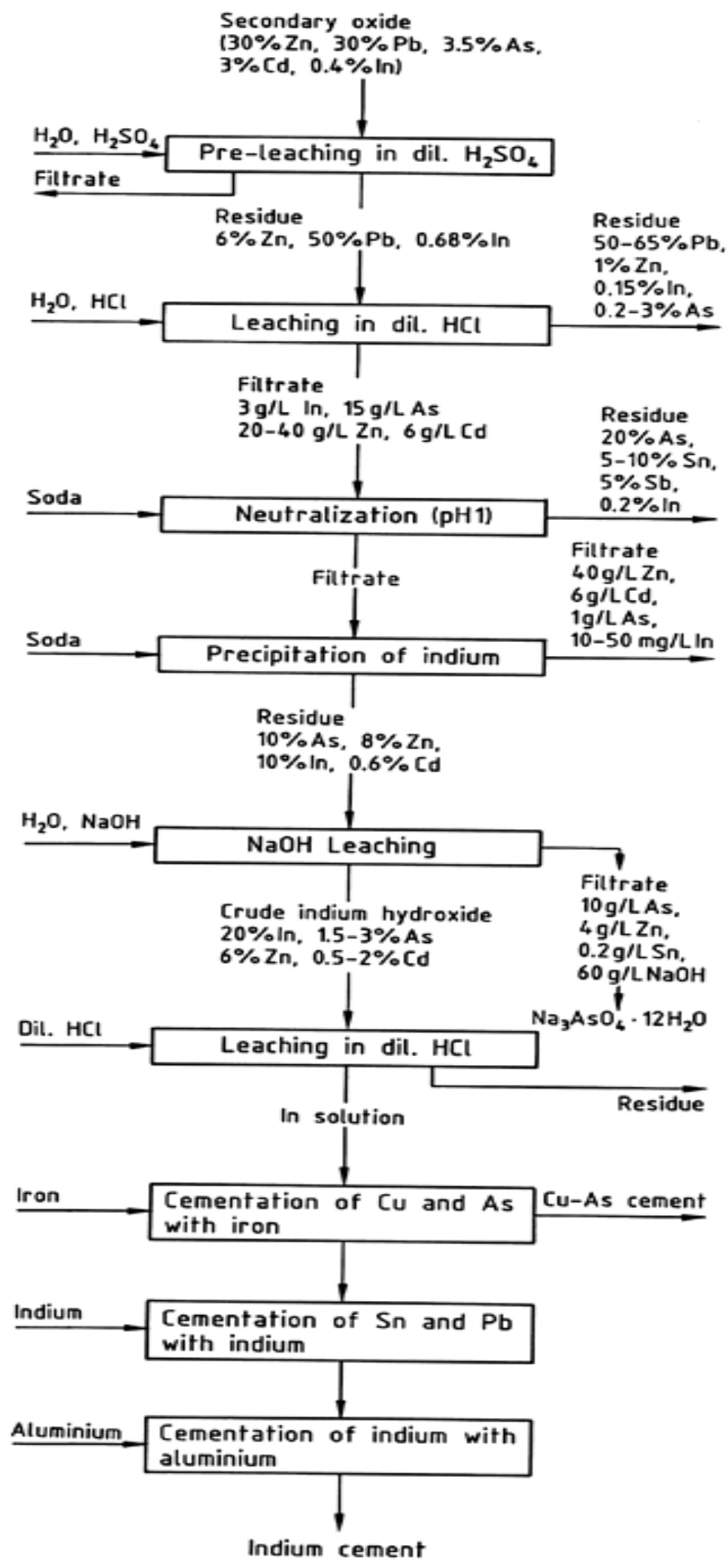

Figure 5. Recovery of Indium from secondary zinc oxide [18] 


\subsubsection{Production Schemes in specific plants}

Teck Cominco Ltd. is one of the world's largest indium producers, generating approximately 36 tonnes of high purity (99.998\% and $99.9999 \%)$ indium per year. It recovers indium from gaseous streams at its integrated zinc and lead in Trail, British Columbia, Canada. Fumes and other particulates from the lead smelter are transferred to the zinc facilities for hydrometallurgical separation and from there to the high-purity indium plant. Fumes generally contain only $0.05 \%$ to $0.2 \%$ In or Ge. The plants then leach the fumes to extract In and Ge into solution (along with $\mathrm{Zn}$ and $\mathrm{Cd}$ ) to separate them form the lead sulfate residue. After a first leaching, slurry is settled to remove a lead oxide residue which is pumped back into the lead smelter, and the clear solution is passed on to a second leach. There, the slurry is partially neutralized with direct fume addition and ferric iron to precipitate germanium, indium, arsenic and antimony. This precipitate is the feed for the indium/germanium recovery plant. The residues from the oxide leaching plant second leach are re-leached with sulfuric acid to dissolve the contained germanium and indium. After filtration, the clear solution is processed in a solvent extraction (SX) unit where both metals are recovered and subsequently re-precipitated to a product for further purification.

The Falconbridge Limited's Kidd Creek operation in Timmins, Ontario is another major producer of indium. The general flowsheet of indium recovery from zinc processing at Kidd Creek is shown in Figure 6. Similar to Tech Cominco's process indium is extracted from the leachate by the solvent extraction (SX) method. The Kidd Creek's indium product is then shipped to the United States for further refining. 


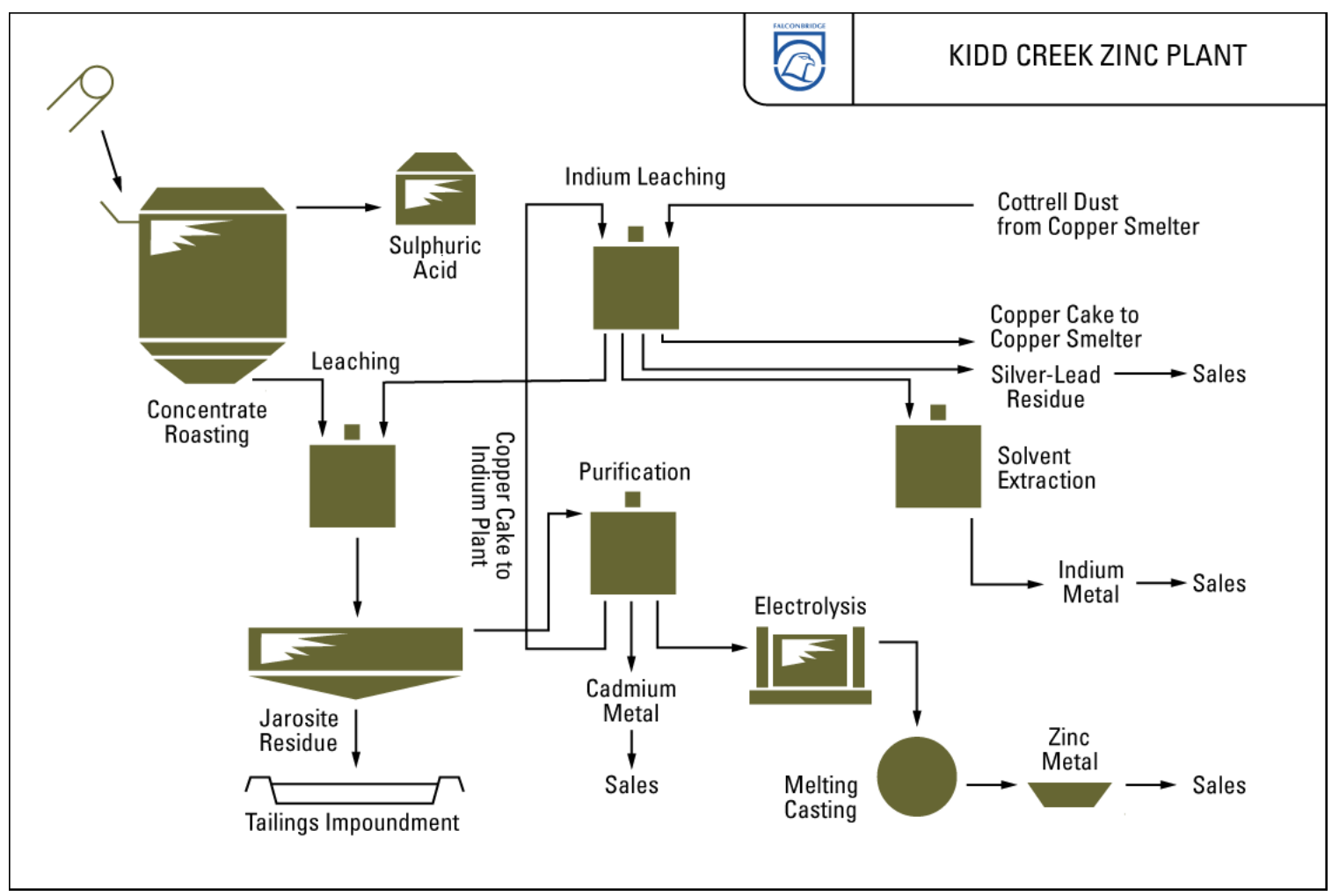

Figure 6. The recovery of indium and cadmium from zinc processing at Kidd Creek, Canada[19]

\subsection{Germanium production}

The major source of germanium is the mineral ore germanite $\left(\mathrm{Cu}_{3}(\mathrm{Ge}, \mathrm{Fe}) \mathrm{S}_{4}\right.$, which is associated with zinc ores and fly-ash of certain coals. It is also a constituent of argyrodite $\left(\mathrm{Ag}_{8} \mathrm{GeS}_{6} \mathrm{Al}\right)$ a more rare mineral. World refinery production was reported to be about 70 tonnes in 2001 and about 50 tonnes in 2002. Zinc recovery represents the largest single source of germanium, with some additional material extracted from electrolytic refining operations for copper and lead. [20, 21, 22]. From the four Canadian producers of zinc only Teck Cominco is reported to produce germanium. The production of germanium consist of generation of germanium concentrate followed by actual production of germanium and germanium oxide. Germanium tetrachloride is hydrolyzed to the dioxide state then reduced to pure metal by carbon or hydrogen. Fractional 
distillations of the tetrachloride separates germanium from other metals and zone refining produces very high purity (up to 9 nines) of germanium for semiconductor use.

Some facilities in the former Soviet Union probably recover germanium from the fly ash of power plants [20]. In Canada, Argento Plata Metals recovers germanium from electronic scrap along with gallium and indium, using a hydrometallurgical process

\subsection{Gallium production}

Gallium occurs in very small concentrations in many rocks and ores of other metals. It is a scarce element found most commonly in association with aluminum, germanium and zinc. About $5 \%$ of the global production of gallium is obtained from residues in zinc-processing; $95 \%$ of the global supply is obtained as a byproduct of alumina production from bauxite (the later is discussed in sections 5.2-5.3). In Zn facilities, as discussed earlier, the zinc ore is leached with sulfuric acid, and the removed impurities include gallium, aluminum and iron. After the zinc is removed, the solution is neutralized to precipitate the metal hydroxides [23]. Hydrochloric acid is used to dissolve gallium and aluminum from the metal hydroxides. Then the gallium is separated from aluminum by solvent extraction with ether. From the distillation, a highly concentrated gallium residue is produced, which still contain iron. Gallium is removed in liquid form by a caustic solution leaving the iron as solid. Finally, the crude gallium is recovered by electrolysis.

In $\mathrm{Zn}$ smelters, when $\mathrm{Ga}$ is not recovered, it ends in the slag.

\section{Purification of Cadmium, Indium and Germanium for Solar Cell Applications}

Teck Cominco reports that all the cadmium they produce is ultra-pure grade (i.e., 99.9999\%). Purification residues from their leaching plants undergo additional leaching with sulfuric acid 
and are filtered through three stages to remove zinc, copper, and thallium. The final step is vacuum-distillation [14].

High purity $\mathrm{Cd}$ and $\mathrm{Te}$ powders from other manufacturers are produced by electrolytic purification and subsequent melting and atomization (see Figure 6(b)), and by vacuum distillation. Both methods are proprietary and information about emissions is not published. According to industry sources, electrolytic purification does not produce any emissions and all waste is recycled. The melting and atomization steps needed to form the powder produce about $2 \%$ emissions that are captured by HEPA filters [24]. The efficiency of HEPA filters in collecting particulates of mean diameter of $0.3 \mu \mathrm{m}$ is $99.97 \%$.
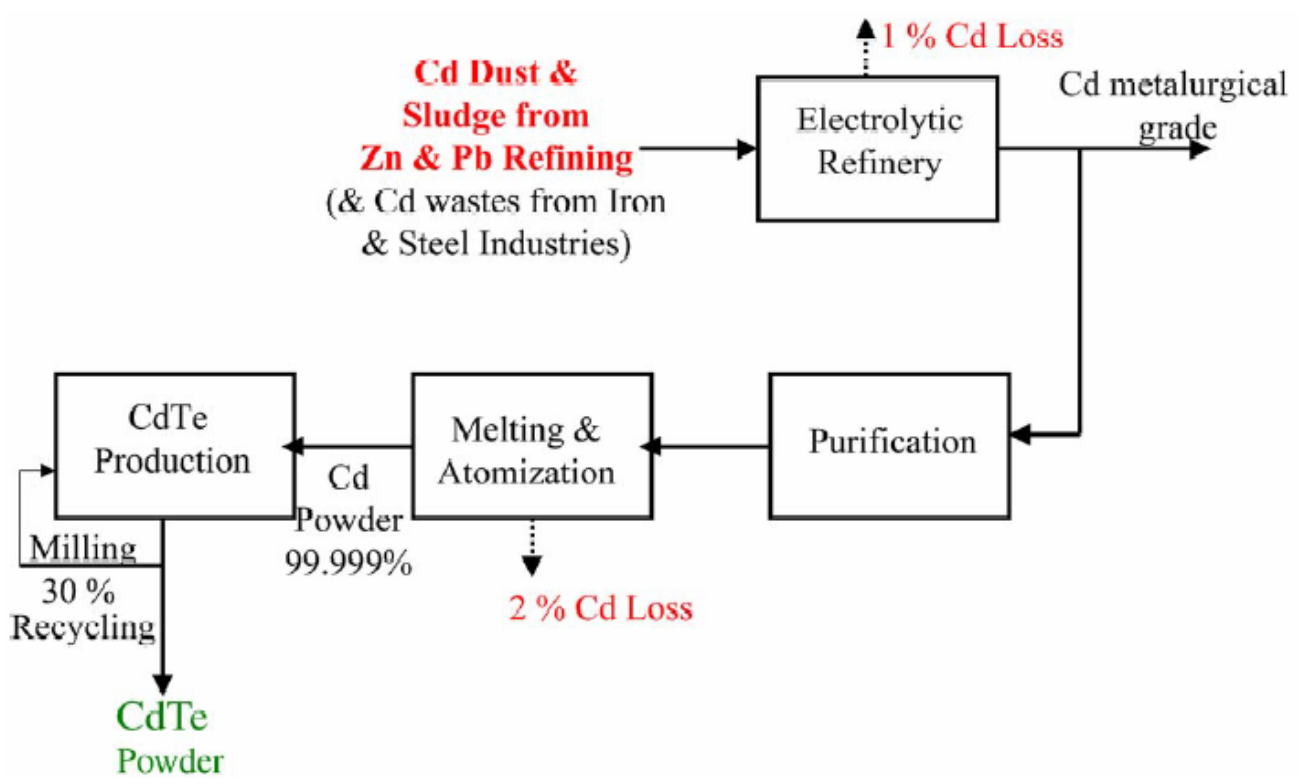

Figure 6(b) Cd Flows from Cd Concentrates to CdTe [11]

Zone-refining involves four steps during which the concentrations of impurities are quickly reduced below levels detected by standard analytical techniques [26,27,28,29]. 


\subsection{Emission Factors in the co-production of $\mathrm{Zn}, \mathrm{Cd}, \mathrm{In}, \mathrm{Ge}$ and Ga}

\subsubsection{Mining}

The extraction, crushing, ore beneficiation, transpot and wind-borne losses could generate significant levels of dust. A range of $0.003 \mathrm{~kg}$ to $27 \mathrm{~kg}$ of dust per ton of ore is reported in the Word Bank Pollution Prevention and Abatement Handbook for global operations during the 80's and the first half of the ninety's [30], but this range inlcudes surface mining that generates much higher emissions. All North American production of zinc is from undrground mines. In addition, the major metal producers in the continent have greatly improved their operations over the last ten years and they implement controls which minimize dust emissions. Water sprays are used to control generation, and scrubbers and cyclones are utilized to collect the dust. TeckCominco uses a wet grinding proces resulting in a slurry from which, reportedly, there are no dust emisions [31]. Falconbridge Ltd reports no air emissions for their Kidd mining division, althought they report metals released to water.

Therefore, the low limit of the total particulate range (i.e., $0.003 \mathrm{~kg} / \mathrm{ton}$ ore) was assumed herein to represent the most likely conditions in today's mining operations in North America.

\subsubsection{Metallurgical Operations}

Production of zinc from zinc concentrates produces air emissions, process wastes, and solidphase wastes. The zinc roasting process primarily emits sulfur dioxide. These emissions often are recovered on-site in sulfuric-acid production plants. Zinc roasters also generate particulates containing cadmium, lead and other metals. The particulate emission streams are controlled with cyclones and electrostatic precipitators (ESPs), and the particulates collected in the control 
equipment constitute hazardous waste. As discussed later, this waste comprises a part of the feed to the cadmium-production plant.

Wastewater produced from leaching, purification and electrowinning usually is treated and reused, or discharged. Solid wastes include slurries from the sulfuric-acid plant, sludge from the electrolytic cells and copper cakes, and the by-products of zinc production from the purification cells which contain cadmium, germanium, indium, and other metals. Much of the waste is RCRA [32] hazardous waste. Copper cakes are captured and sold to copper processing plants. Purification by-products and other solid wastes are recycled or stockpiled until they can be economically used. Table 1 shows the US EPA's estimates of particulate emissions for US plants; we estimated their cadmium content based on a typical concentration of $\mathrm{Cd}$ in $\mathrm{Zn}$ concentrate (e.g., $0.5 \%)$.

Table 1. Particulate Emission Factors in Zinc Smelting by Thermal (Old) and Electrolytic (New) Methods

\begin{tabular}{|c|c|c|c|}
\hline Process & $\begin{array}{l}\text { Uncontrolled } \\
\text { Emissions } \\
\text { ( } \mathrm{kg} / \mathrm{t} \text { of zinc ore) }\end{array}$ & $\begin{array}{l}\text { Post-control } \\
\text { Emissions } \\
(\mathrm{kg} / \mathrm{t} \text { of zinc } \\
\text { concentrate) }\end{array}$ & $\begin{array}{l}\text { Estimated }{ }^{*} \mathrm{Cd} \\
\text { Emissions } \\
(\mathrm{kg} / \mathrm{t} \text { of zinc } \\
\text { concentrate) }\end{array}$ \\
\hline $\begin{array}{l}\text { Roasting } \\
\text { Multiple hearth } \\
\text { Suspension } \\
\text { Fluidized bed }\end{array}$ & $\begin{array}{l}113 \\
1000 \\
1083\end{array}$ & $\begin{array}{l}\text { ND } \\
4 \\
\text { ND }\end{array}$ & $\begin{array}{l}\mathrm{ND} \\
0.02 \\
\mathrm{ND}\end{array}$ \\
\hline $\begin{array}{l}\text { Sinter plant } \\
\text { Uncontrolled } \\
\text { With cyclone } \\
\text { With cyclone and } \mathrm{ESP}^{\mathrm{a}}\end{array}$ & $\begin{array}{l}62.5 \\
\text { NA } \\
\text { NA }\end{array}$ & $\begin{array}{l}\text { NA } \\
24.1 \\
8.25\end{array}$ & $\begin{array}{l}\text { NA } \\
0.14 \\
0.05\end{array}$ \\
\hline Vertical retort & 7.15 & ND & ND \\
\hline $\begin{array}{l}\text { Electric retort (electrothermic } \\
\text { process) }\end{array}$ & 10.0 & ND & ND \\
\hline Electrolytic process & 3.3 & ND & ND \\
\hline
\end{tabular}

"Cadmium content in particulates is estimated assuming a zinc/cadmium ratio of $200(0.5 \% \mathrm{Cd})$.

${ }^{a}$ Data not necessarily compatible with uncontrolled emissions

ND: not detected 
Berdowski et al., [33] reported on the emissions from zinc-smelting operations in other countries; these are summarized in Table 2. Cd emissions vary widely depending on the ore used and the abatement measures applied. For electrolytic production, emission factors of $0.5 \mathrm{~g}$ Cd/ton Zn were reported in 1992 for the Netherlands, 2 g Cd/ton Zn in 1991 for Germany, and a range of 0.4-20 was reported for 1980-1992 for Poland. More recent (2000) data show $0.2 \mathrm{~g} \mathrm{Cd}$ per tonne of metal product for North European countries [34,35].

Table 2. Emission factors for primary zinc production (g/ton-product) [33]

\begin{tabular}{|c|c|c|c|c|c|c|c|}
\hline \multirow[t]{2}{*}{ Compound } & \multicolumn{2}{|c|}{ Germany 1991} & \multicolumn{2}{|c|}{ Poland $1980-1992$} & \multirow{2}{*}{$\frac{\text { Netherlands } 1992}{\text { Electrolytic }}$} & \multicolumn{2}{|c|}{ Europe 2002} \\
\hline & Thermal & Electrolytic & Thermal & Electrolytic & & Thermal & Electrolytic \\
\hline Cadmium & 100 & 2 & 13 & $0.4-29$ & 0.5 & $50^{\mathrm{a}}$ & 0.2 \\
\hline Lead & 450 & 1 & $31-1000^{\mathrm{b}}$ & $2.3-467$ & - & 1900 & - \\
\hline Mercury & $5-50$ & - & - & - & - & 8 & - \\
\hline Zinc & - & - & $420-3800$ & $47-1320$ & 120 & 16,000 & 6 \\
\hline
\end{tabular}

a With vertical retort and limited abatement: $200 \mathrm{~g} / \mathrm{Mg}$ product; with imperial smelting furnace: $50 \mathrm{~g} /$ $\mathrm{Mg}$ product.

${ }^{b}$ Limited abatement. 
Table 3. Production and Emissions at the Trail Smelter and Refineries, British Columbia, Canada [Teck Cominco Ltd, 2003] [14]

\begin{tabular}{|c|c|c|c|c|c|c|c|}
\hline & 1998 & 1999 & 2000 & 2001 & 2002 & 2003 & 2004 \\
\hline \multicolumn{8}{|l|}{ Annual Production (tonne) } \\
\hline Zinc & \multicolumn{7}{|c|}{$274,300288,700272,900168,100269,000283,100296,000$} \\
\hline Lead & 63,900 & 75,700 & 91,300 & 55,200 & 80,700 & 87,800 & 84,300 \\
\hline Cadmium & $969 *$ & $1020 *$ & $964 *$ & $594^{*}$ & $950^{*}$ & 1000 & $* 1050$ \\
\hline Specialty Metals & $\mathrm{N} / \mathrm{A}$ & 28 & 28 & 28 & 28 & $\mathrm{~N} / \mathrm{A}$ & N/A \\
\hline Indium & $31 *$ & $33 *$ & $31 *$ & $19 *$ & 31 & 34 & 42 \\
\hline Silver & 463 & 431 & 463 & 348 & 550 & 569 & 613 \\
\hline Gold & 3 & 2 & 2 & 2 & \multicolumn{3}{|l|}{5} \\
\hline Fertilizer & \multicolumn{7}{|c|}{$273,000240,700220,300167,500225,000$} \\
\hline \multicolumn{8}{|l|}{$\begin{array}{l}\mathrm{Cd} \text { Releases to } \\
\text { Operations }(\mathrm{kg} / \mathrm{yr})\end{array}$} \\
\hline & & 600 & 250 & 100 & 95 & & \\
\hline \multicolumn{2}{|l|}{ ( $\mathrm{g}$ of $\mathrm{Cd} / \mathrm{t}$ metal products) } & 1.64 & 0.69 & 0.45 & 0.27 & & \\
\hline $\begin{array}{l}\mathrm{Cd} \text { Releases to Water } \\
\text { Operations } \\
(\mathrm{kg} / \mathrm{yr})\end{array}$ & & 208 & 290 & 170 & 208 & & \\
\hline ( $\mathrm{g}$ of $\mathrm{Cd} / \mathrm{t}$ metal products) & & 0.57 & 0.79 & 0.76 & 0.59 & & \\
\hline
\end{tabular}

*: Estimated based on 2003's production levels

Slightly higher emissions (i.e., $0.27 \mathrm{~g} \mathrm{Cd} / \mathrm{t}$ metal) are reported from the Teck Cominco integrated zinc- and lead-smelting and refining facilities in Trail, British Columbia, Canada [36]. Most likely, the difference is due to the pyrometallurgical lead production in this facility. In addition to zinc and lead, eighteen other products are formed including silver, gold, indium, germanium, bismuth, copper products; and sulfur compounds (e.g., ammonium sulphate fertilizer, sulfuric acid, liquid sulfur dioxide and elemental sulfur). The reported cadmium releases from all operations at Trail in 2002 were $95 \mathrm{~kg}$ in air and $208 \mathrm{~kg}$ in water; they correspond, per tonne of 
metals produced, to $0.27 \mathrm{~g}$ of $\mathrm{Cd}$ air emissions, and $0.59 \mathrm{~g}$ of water discharges (Table 3). Only total emissions from all operations were reported; the contribution of the cadmium plant to these emissions is difficult to determine because feeds and residuals were transferred between plants in the same facility. Also, the Trail smelting facility processes metal scrap and other waste in addition to $\mathrm{Zn}$ and $\mathrm{Pb}$ ores. These data show a continuing improvement from 1989 to 2002. The actual emissions of Cd into the air declined by $84 \%$ between 1999 and 2002 (Table 3). Releases in the water within this period remained approximately the same.

The production and emission factors from another very large Canadian facility, the Falconbridge Limited's Kidd Creek smelter and refineries, are listed in Table 4.

Table 4. Production and emissions at Falconbridge Ltd. Kidd Creek smelter and refineries, Timmins, Ontario

\begin{tabular}{|c|c|c|c|c|c|}
\hline Year $\rightarrow$ & 1997 & 1998 & 1999 & 2000 & 2001 \\
\hline \multicolumn{6}{|l|}{ Production (Tonne) } \\
\hline Total ore milled & $3,302,829$ & $2,544,552$ & $2,436,126$ & $2,274,771$ & $1,950,216$ \\
\hline Mill tailings produced & $2,560,662$ & $2,108,253$ & $2,017,494$ & $1,932,381$ & $1,634,112$ \\
\hline Total metals produced & 250,117 & 269,251 & 252,356 & 264,368 & 267,897 \\
\hline Copper produced & 122,953 & 124,147 & 122,966 & 124,529 & 132,100 \\
\hline Zinc produced & 126,320 & 145,100 & 131,100 & 141,400 & 140,073 \\
\hline Cadmium produced & 820 & $940 *$ & $850^{*}$ & $920^{*}$ & $910^{*}$ \\
\hline Indium produced & 24 & 22 & $20 *$ & $21^{*}$ & $21^{*}$ \\
\hline $\begin{array}{ll}\text { Sulfuric } & \text { acid } \\
\text { produced } & \end{array}$ & $\mathrm{N} / \mathrm{A}$ & 543,700 & 496,400 & 545,800 & 514,300 \\
\hline \multicolumn{6}{|l|}{ Air emissions } \\
\hline $\begin{array}{l}\mathrm{SO}_{2} \text { emissions }(\mathrm{kg} / \mathrm{t}- \\
\text { metal })\end{array}$ & 20.95 & 18.31 & 20.25 & 14.44 & 14.29 \\
\hline $\begin{array}{l}\mathrm{CO}_{2} \text { emissions }(\mathrm{kg} / \mathrm{t}- \\
\text { metal })\end{array}$ & 1373 & 1210 & 1196 & 1213 & 1200 \\
\hline
\end{tabular}




\begin{tabular}{|c|c|c|c|c|c|}
\hline \multicolumn{6}{|c|}{ Metals released to water $(\mathrm{kg})$} \\
\hline As & 80 & 80 & 97 & 80 & 106 \\
\hline $\mathrm{Cd}$ & 140 & 50 & 120 & 205 & 102 \\
\hline $\mathrm{Cr}$ & 450 & 70 & 70 & 32 & 34 \\
\hline Co & 60 & 80 & 110 & 302 & 85 \\
\hline $\mathrm{Cu}$ & 370 & 550 & 550 & 683 & 1220 \\
\hline $\mathrm{Pb}$ & 60 & 90 & 147 & 154 & 166 \\
\hline $\mathrm{Hg}$ & $<\mathrm{dl}$ & $<\mathrm{dl}$ & $<\mathrm{dl}$ & $<\mathrm{dl}$ & $<\mathrm{dl}$ \\
\hline $\mathrm{Ni}$ & 370 & 100 & 155 & 118 & 231 \\
\hline $\mathrm{Ag}$ & 50 & 70 & 80 & 33 & 33 \\
\hline $\mathrm{Zn}$ & 6,200 & 3,020 & 6,267 & 12,288 & 27,361 \\
\hline Total to water $(\mathrm{kg})$ & 7,780 & 4,110 & 7,596 & 13,895 & 29,320 \\
\hline \multicolumn{6}{|c|}{ Metals released to air $(\mathrm{kg})$} \\
\hline As & 5,120 & 1,450 & 1,425 & 1,291 & 1,450 \\
\hline $\mathrm{Cd}$ & 610 & 580 & 483 & 548 & 500 \\
\hline $\mathrm{Cr}$ & 250 & 260 & 229 & 238 & 240 \\
\hline Co & 65 & 40 & 39 & 41 & 40 \\
\hline $\mathrm{Cu}$ & 59,100 & 65,700 & 59,278 & 66,094 & 61,000 \\
\hline $\mathrm{Pb}$ & 63,080 & 75,590 & 28,694 & 25,559 & 30,000 \\
\hline $\mathrm{Hg}$ & $<10$ & $<10$ & $<10$ & $<10$ & $<10$ \\
\hline $\mathrm{Ni}$ & 290 & 280 & 223 & 239 & 230 \\
\hline $\mathrm{Ag}$ & 280 & 230 & 217 & 227 & 230 \\
\hline $\mathrm{Zn}$ & 33,800 & 30,410 & 32,312 & 32,562 & 36,500 \\
\hline Total to air (kg) & 162,595 & 174,540 & 122,900 & 126,799 & 130,190 \\
\hline
\end{tabular}


Annotation: "<dl” means below detection limit; "n/a" means not available.

Data sources: 2001 Action Plan and Performance Data, Site Reports of Kidd Metallurgical Division, Falconbridge Limited, http://www.falconbridge.ca

Falconbridge LTd., Energy Intensity Improvement and Green House Gas Reduction Action Plan, 2000, http://www.falconbridge.com/pdfs/VCR2000.pdf

Pollution Probe, Sulphur dioxide and toxic metal emissions form smelters in Ontario, Feb. 2003, http://www.pollutionprobe.org/Publications/Smelter\%20Report.pdf

*: Estimated based on 1997's production level.

As can seen from this table, the major metals emitted to air are $\mathrm{Pb}, \mathrm{Cu}, \mathrm{Zn}$, and As with pyrometallurgical unit operations, such as roasting, and smelting. Also, the release of zinc to the water is significant in the leaching/electrolysis processes. The reported cadmium releases from all operations at Kidd Creek in 2001 was $1.86 \mathrm{~g} /$ tonne-metal air emissions, and $0.38 \mathrm{~g} /$ tonnemetal of water discharges.

The SimaPro 6.0 version includes emission factors for zinc from the Ecoinvent and ETH-ESU databases. The first shows $\mathrm{SO}_{2}$ emissions of $1.27 \mathrm{~kg} / \mathrm{t}$-zinc in high population locations and 21.9 $\mathrm{kg} / \mathrm{t}$-zinc in low population locations. The second date-base gives one value, i.e., $30.3 \mathrm{~kg} / \mathrm{t}$-zinc. The emission of cadmium in air are reported in Ecoinvent to be $0.044 \mathrm{~g} / \mathrm{t}$-metal in high population locations and $4.4 \mathrm{~g} / \mathrm{t}$-metal in low-population locations. These emissions in ETH-ESU are reported to be $50 \mathrm{~g} / \mathrm{t}$-metal; the corresponding technology is described as "outdated".

\subsection{Energy Factors in the co-production of $\mathrm{Zn}, \mathrm{Cd}$, In, Ge and Ga}

\subsubsection{Mining}

At Teck Cominco's Reg Dog mine, which supplies 51\% of the feedstock of the Trail metallurgical operations, the fuel (primary) energy consumption in the period of 1995 to 2003 was about constant at 0.8 
$\mathrm{GJ} /$ tonne of ore mined. The zinc concentration in the ore is about $21 \%$, which corresponds to $\sim 1.1 \mathrm{MJ}$ /tonne metal produced. ${ }^{7}$

In the Falconbridge Kidd Creek mining operation, energy use of 0.02 to $0.03 \mathrm{MWh} /$ tonne of ore mined is reported for the period of 1997 to 2000; whereas $0.19 \mathrm{MWh} /$ tonne is reported for 1996 and $0.15 \mathrm{MWh} /$ tonne for 2001 . The ore mined in this location contains about $5 \%$ zinc and $2.1 \%$ copper. Correspondingly the fuel energy factors are 1.4 to $8.6 \mathrm{MJ} /$ tonne zinc and 3.4 to 20.5 $\mathrm{MJ} /$ tonne copper ${ }^{8}$. The raw data support the high bound in these ranges.

\subsubsection{Metallurgical Operations}

At Teck Cominco's Trail operations, the total energy consumption in 2003 was 40 GJ/tonnemetal, down from 65 GJ/Tonne-metal in 1990 [37]. These data include the entire site and all processes that use energy. TeckCominco run several additional unit operations, compared with most other smelters, to produce a much wider range of products and all of these unit processes consumed energy. For example, most zinc plants simply put their residues into a tailings pond while TeckCominco smelts them and use a slag fumer to recover zinc and concentrate elements like In and Ge. They also run a precious metals refinery and lead refining unit that consume disproportionally high energy. In addition they produce ammonium fertilizer, liquid $\mathrm{SO}_{2}$ and gypsum, all of which consume energy that is allocated to the metal production. Electric power for the Trail operations is generated by the company's Waneta Hydroelectric Dam. Ore grade (Red Dog Mine): $\mathrm{Zn}-20 \sim 22 \%, \mathrm{~Pb}-4.7 \sim 6.2 \%$. A large portion of the zinc concentrates treated at Trail comes from Red Dog in Alaska (51\%) and Sullivan in Kimberley, B.C. (41\%) and the remainder $(8 \%)$ from other sources. Lead concentrates are received in gondola cars from the

\footnotetext{
${ }^{7}$ Production link: http://www. teckcominco.com/operations/reddog/production. htm Energy \& emissions link: http://www. teckcominco. com/operations/reddog/sustainability. htm
} 
Sullivan mine in Kimberley, B.C. and from various other custom concentrators in the U.S. and South America

In the Falconbridge Kidd Creek metallurgical operations, the total energy consumption is reported to be about $25 \mathrm{MJ} / \mathrm{kg}$-metal in the period 1997-2001. The metallurgical division consists of a concentrator, a copper smelter and refinery, a zinc plant, a cadmium plant, an indium plant and a sulphuric acid plant. The Kidd Creek's ore contains $2.10 \%$ copper and 5.0\% zinc. Both facilities use electrolytic production of zinc and pyrometallurgical production of lead (Kivcet "flash" smelter, Trail) or copper (Michubishi “bath" smelter, Kidd Creek). Allocation of the total energy to the production of each metal is not given, neither can be easily calculated due to the integration of the co-production.

The total energy intensities of the four facilities are shown in Figure 7.

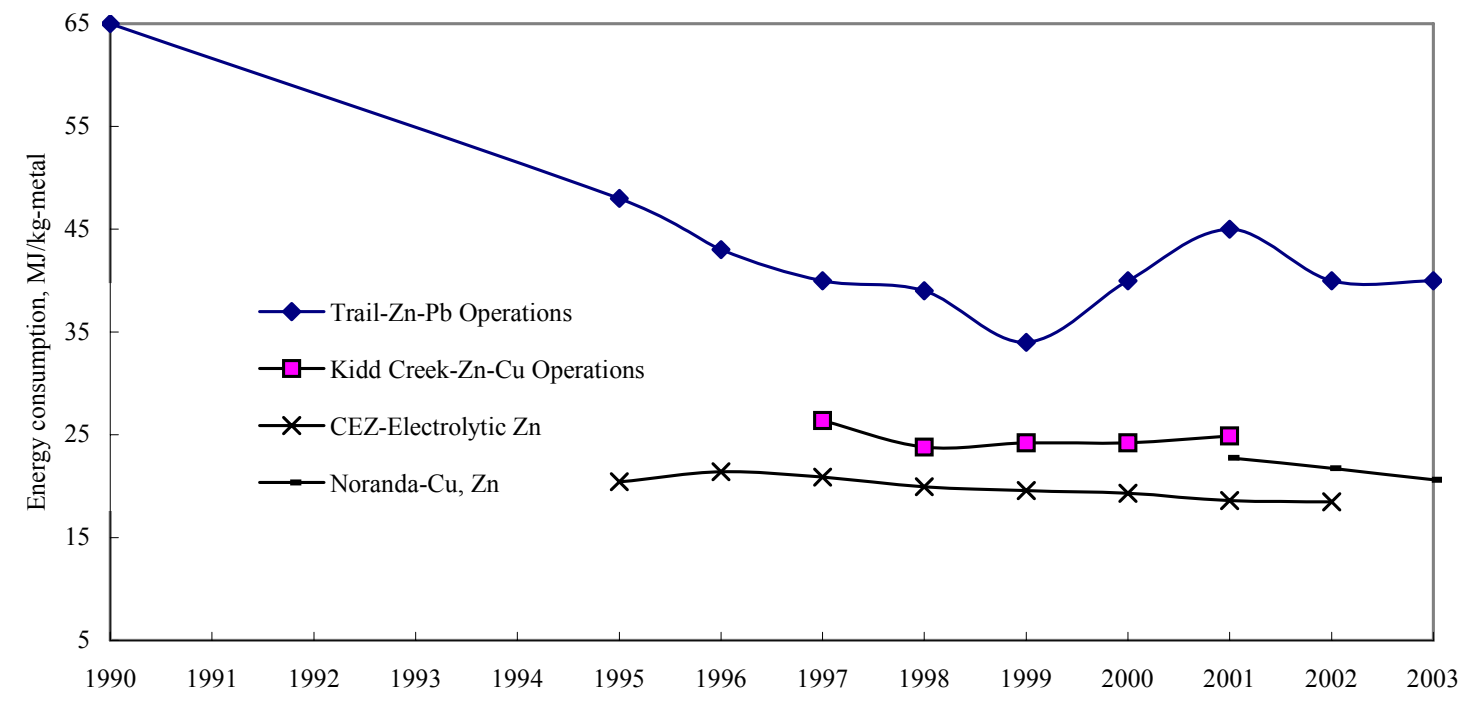

Figure 7 Energy Intensity in major Canadian $\mathrm{Zn}-\mathrm{Pb}$ and $\mathrm{Zn}-\mathrm{Cu}$ Operations

A recent life cycle analysis of lead and zinc production in Australia [13] shows that when zinc and lead are produced separately, zinc by the electrolytic process and lead by the blast furnace

8: http://www. falconbridge. com/index home. html 
process, the zinc production is ore than two times more energy intensive as lead production (i.e $48 \mathrm{MJ} / \mathrm{kg}$ versus $20 \mathrm{MJ} / \mathrm{kg}$. The production of Zinc via Imperial Smelting Process is reported to be $36 \mathrm{MJ} / \mathrm{kg}-\mathrm{Zn}[13]$.

Table 5 Electricity consumption $(\mathrm{MJ} / \mathrm{kg}-\mathrm{Zn}-\mathrm{Pb})$ for process stages [13]

\begin{tabular}{llllll}
\hline \multicolumn{1}{c}{ Lead } & \multicolumn{5}{c}{ Zinc } \\
\hline Imperial Smelting Process & & & Imperial Smelting Process & MJ/kg-Zn & $\%$ \\
& $\mathrm{MJ} / \mathrm{kg}-\mathrm{Pb}$ & $\%$ & & 0.42 & 12.8 \\
Mining & 0.43 & 14.1 & Mining & 0.21 & 6.3 \\
Mineral Processing & 0.21 & 6.9 & Mineral Processing & 58.8 \\
Sintering \& Acid Plant & 1.98 & 65.1 & Sintering \& Acid Plant & 1.92 & 19.2 \\
Imperial Smelting Furnace & 0.41 & 13.5 & Imperial Smelting Furnace & 0.63 & 2.8 \\
Refining & $\underline{0.01}$ & 0.4 & Refining & $\underline{0.09}$ & $\underline{3.25}$ \\
Total & $\underline{3.03}$ & $\underline{100.0}$ & Total & $\mathrm{MJ} / \mathrm{kg}-\mathrm{Zn}$ & $\%$ \\
Blast Furnace Process & & & Electrolytic Process & 0.0 \\
& $\mathrm{MJ} / \mathrm{kg}-\mathrm{Pb}$ & $\%$ & & 1.10 & 2.9 \\
Mining & 0.40 & 9.8 & Mining & 6.9 \\
Mineral Processing & 0.95 & 23.5 & Mineral Processing & 18.1 \\
Sintering \& Acid Plant & 2.12 & 52.3 & Roasting/Leaching/Acid Plant & 2.88 & 72.2 \\
Blast Furnace & 0.58 & 14.2 & Electrolysis & $\underline{11.52}$ & \\
Refining & $\underline{0.01}$ & 0.3 & & $\underline{15.96}$ & 100 \\
Total & $\underline{4.06}$ & $\underline{100.0}$ & Total & & \\
\hline
\end{tabular}

The SimaPro 6.0 version includes energy factors for zinc from the Ecoinvent and ETH-ESU databases. The first lists $49.8 \mathrm{MJ} / \mathrm{kg}$ metal as the total energy for the production of high-grade primary zinc (80\% from hydrometallurgical and 20\% from pyrometallurgical processes), including disposal of the slag and treatment of waste water. The second data base shows 84.6 $\mathrm{MJ} / \mathrm{kg}$ metal based on a 1979 publication.

\section{Production of Lead and By-Products (Cd)}

Similarly to zinc ores, lead-bearing ores are processed by crushing, screening and milling to reduce the ore to powder, they are concentrated by flotation, separation and drying and the concentrates are transferred to smelters for the production of metals. Lead operations are many 
times integrated with zinc operations, as in the TeckCominco, Trail Operations, described in Section 3.2).

Globally, as of 2001, about $80 \%$ of the lead production is based on the Blast Furnace process and $10 \%$ on the Imperial Smelting process. Other processing routes, (e.g. Kivcet "flash" furnace), account for the balance of the global production.

Most lead smelters are designed to treat a wide range of feed materials including lead concentrates, residues from the zinc plants, recycled lead battery scrap, and scrap copper [38].

Blast furnaces are described in the copper section Below we summarize the newer flash furnace, which eliminates the need for sintering and significantly reduces dust and fume emissions. The lead concentrates are heated in a furnace with oxygen, silica and limestone for fluxing, residues from other plants (e.g., zinc) recycled battery scrap, and dry fine coal for fuel. The sulfur in the concentrates and the fine coal ignite instantly and concentrated (i.e., 15\%) sulfur dioxide and oxides of lead, zinc, iron and minor metals are formed. The fluxing agents and the oxides form a slag, the burning coke floats at the top of the molten slag, and the metal oxides percolate though to form metal bullion at the bottom. The bullion is further processed through a drossing furnace to remove and recover copper, arsenic and antimony. After this purification, the bullion is poured into ingots and transferred to the lead refinery for electro-refining, which produces slimes that are treated in a series of furnaces to recover silver, gold and bismuth. The purified bullion is then cast into the finished products. The lighter slag is transferred to a slag furnace to remove zinc, mainly in the form of a zinc-oxide fume. The fume is processed in the leaching plants in zinc operations to extract more zinc. The remaining "ferrous granules" (black sand-like slag) is sold to cement manufacturers. 
Energy is recovered from the hot-emissions by passing the gasses through a heat exchanger, while an electrostatic precipitator removes the particles. The $\mathrm{SO}_{2}$ emissions then are processed into sulfur products (e.g., sulfuric acid and liquid sulfur dioxide) [38].

\section{Emission factors}

Emissions of heavy metal from lead smelters are tabulated in Table 3. Cadmium from all sources range from $0.6 \mathrm{~g} / \mathrm{t}$ - product for plants with cyclones and ESPs, to $22 \mathrm{~g} / \mathrm{t}$-product for plants with limited emissions abatement (Table 3).

\section{Production of Copper and By-products (Mo, Se and Te)}

\subsection{Ore Mining and Beneficiation}

Copper is found in many minerals such as cuprite $\left(\mathrm{Cu}_{2} \mathrm{O}\right)$, malachite $\left(\mathrm{CuCO}_{3} \cdot \mathrm{Cu}(\mathrm{OH})_{2}\right)$, azurite $\left(2 \mathrm{CuCO}_{3} \cdot \mathrm{Cu}(\mathrm{OH})_{2}\right)$, chalcopyrite $\left(\mathrm{CuFeS}_{2}\right)$, and bornite $\left(\mathrm{Cu}_{5} \mathrm{FeS}_{4}\right)$. The most important copper ores are the sulfides and oxides. Globally, about $80 \%-90 \%$ of the primary copper production is derived from sulfide ores [39], the balance is derived from oxide ores. The copper ores are of low grade, often less than $1 \% \mathrm{Cu}$. Copper from currently mined ores averages around $0.8 \%$ in grade globally. In addition to its primary production, copper is also produced by recycled scraps (secondary production). In 2001, copper recovered from all refined or re-melted scrap composed $34 \%$ of the total U.S. copper supply [40] and in 2003 this contribution was $31 \%$ of the U.S. copper supply [41]. The world wide land-based resources are estimated to be 1.6 billion tons of copper, and resources in deep-sea nodules are estimated to be 700 million tons. In the United States, discovered resources are estimated to contain 350 million tons of copper, and undiscovered deposits are estimated to contain 290 million tons of copper [41]. Major mining 
operations are located in the United States, Chile, Peru, Mexico and Canada. The ores are mined in both open pits and underground mines, depending upon the ore grade and the nature of the ore deposit. Once the ore is delivered above the ground, it is crushed, ground and concentrated (beneficiated) for further processing. In the beneficiation process, ground ore is slurried with water, chemical reagents (e.g., xanthates, alcohols, pine oil) are added, and air is blown through the slurry. The air bubbles attach themselves to the copper minerals and are then skimmed off of the top of the flotation cells. The concentrate contains between 20 and 30 percent copper. The "tailings," or gangue minerals, from the ore fall to the bottom of the cells and are removed, dewatered by "thickeners," and transported as a slurry to a tailings pond for disposal. All water used in this operation, from dewatering thickeners and the tailings pond, is recovered and recycled back into the process [42].

\subsection{Copper production}

Copper is produced either pyrometallurgically or hydrometallurgically depending upon the ore-type. Concentrates produced from copper sulfide ores are treated by pyrometallurgical processes whereas those from copper oxide ores, are usually treated by hydrometallurgical processes together with oxidized waste materials. The pyrometallurgy of copper is a multistage process, beginning with the mining and concentrating of low-grade ores containing copper sulfide minerals, and followed by smelting and electrolytic refining to produce a pure copper cathode. About $80 \%$ of the world's primary copper is produced from sulfide ores such as chalcopyrite $\left(\mathrm{CuFeS}_{2}\right)$. The hydrometallurgical route, known as leaching-solvent extractionelectro-winning (SX-EW), involves leaching, solvent extraction, and recovery by precipitation or electrowinning. In the United States, about $70 \%$ of domestic primary refined copper is produced from a multistage process, beginning with the mining and concentrating of ores, and followed by 
smelting and electrolytic refining to produce a high-grade copper cathode. The rest $30 \%$ is produced from acid leaching of copper ores and wastes and solvent extraction and electrowinning of refined copper from the pregnant solution. A general flowchart for the extractive metallurgy of copper is shown in Figure 8.
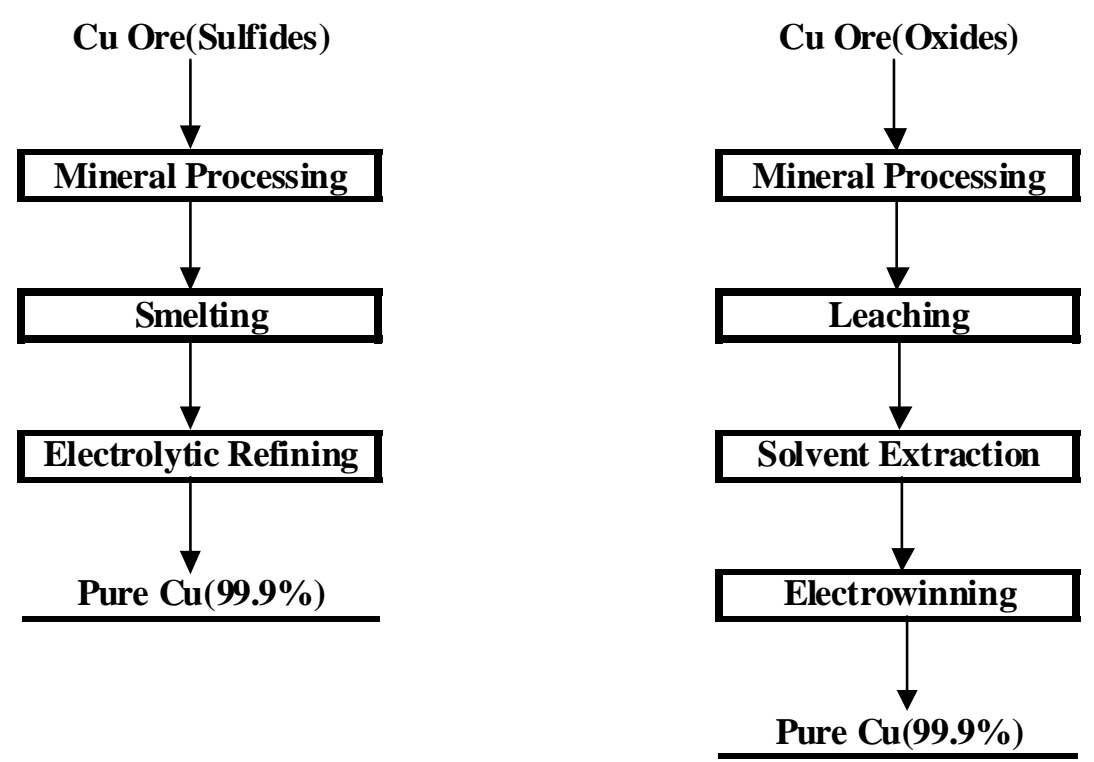

(a) Pyrometallurgical Processing of Sulfide Concentrates

\section{(b)Hydrometallurgical Treatment of Oxide Ores}

Figure 8. Extractive metallurgy of copper

\subsection{Pyrometallurgical Processing}

Pyrometallurgical processes employ high-temperature chemical reactions to extract copper from its ores and concentrates. The traditional pyrometallurgical copper smelting process is schematically shown in Figure 9. Generally, these processes are used with low-grade or poor copper sulfides and, in some cases, high-grade oxides. Depending on the copper mineral and the type of equipment, pyrometallurgical processing from copper concentrates follows the following sequence $[39,43,44,45]$ : 


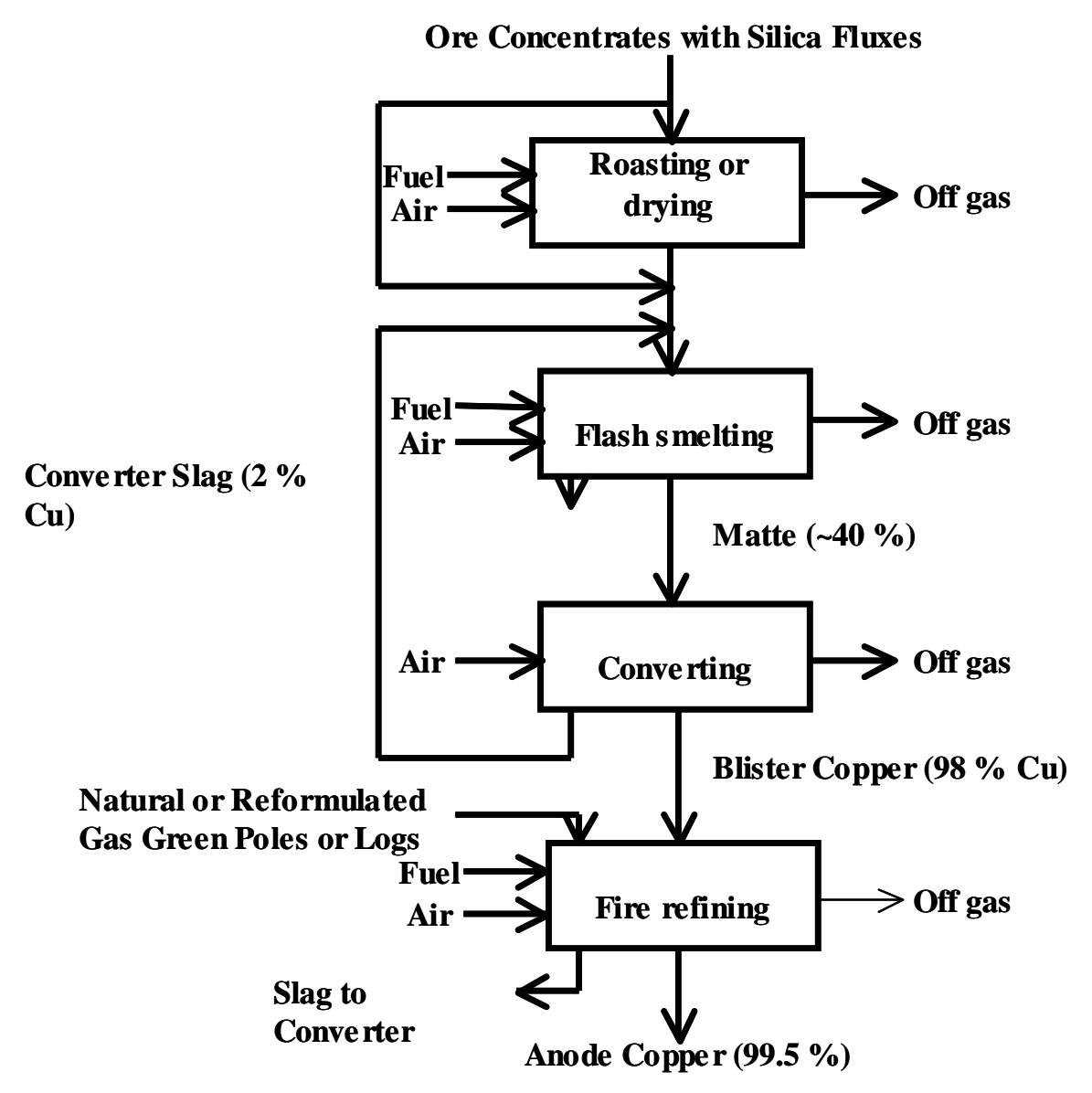

Figure 9. Typical primary copper smelter process [99]

Roasting to obtain oxidized material or calcified material (older smelters); two-stage pyrometallurgical extraction; smelting concentrates to matte; converting matte to blister copper

+Refining the crude copper, usually occurs in two steps: a) Pyrometallurgically to fire-refined copper; b) electrolytically to high-purity electrolytic copper

Roasting. The purpose of the roasting is to decrease the sulfur content to an optimum level prior to form copper. Roasting is a process to convert copper and iron sulfide concentrates (25\%-30\% 
$\mathrm{Cu}$ ) to oxides, thereby removing most of the sulfur (as sulfur dioxide). Two main types of furnaces have been used, viz. multiple hearths, and fluidized bed roasters. In modern copper smelters, roasting has been abandoned as a separate step and has been combined with the smelting furnace.

Smelting. Smelting involves the application of heat to a charge of copper ore concentrate, scraps, and flux to fuse the ore and allow the separation of copper from iron and other impurities. Smelting is a critical step in copper production. Modern copper smelting furnaces accommodate both roasting and smelting operations in one unit. There are four major types of copper smelters in use, namely reverberatory furnaces, electric furnaces, flash smelters and bath smelters. The first two are essentially batch-type and consequently inherently less efficient than the latter two types. Therefore, the latter two are more and more widely used. Flash smelting employs oxygenrich air to promote autogenous conditions while bath smelting is dependent upon the roasting and smelting steps occurring within a molten pool containing both matte and slag phases. There are two types of flash smelters, the Outokumpu and INCO systems. In both cases a finely divided dry concentrate is fed into a hearth-type furnace. The Outokumpu flash smelting process combines the conventional operations of roasting, smelting and partial converting into one process. Preheated oxygen-enriched air (about $25 \% \mathrm{O}_{2}$ ) is used to provide heat so that additional fuel is not required for the reactions to proceed. Copper concentrate is recovered from the slag and recycled through the smelter. The clean slag is sent for disposal. Heat and particulates are recovered from the smelter gases using bag-houses and wet scrubbers, and the collected residues are recycled in the smelter. Gaseous stream containing $10-30 \%$ of $\mathrm{SO}_{2}$ is used for production of sulfuric acid. The matte is further treated in conventional converters to obtain blister copper. The main advantages of the Outokumpu process are the high sulfur recovery, the efficient energy 
utilization, and the flexible process in terms of accepting a varied feed material. Energy consumption for the new technology is about 20 to $30 \%$ of that required with a conventional furnace. $50-80 \%$ of sulfur is recovered from the concentrate for use in sulfuric acid production, reducing $\mathrm{SO}_{2}$ emissions to the environment. Slag cleaning reduces copper content from $24 \%$ to less than $0.6 \%$ prior to disposal, eliminating problems due to liquid run-off from granulation pond. This process utilizes dry copper concentrates. This process, developed by Outokumpu Technology Oy, produces half of the world's primary copper. The flowsheet of Outokumpu's flash smelting process [55] is shown in Figure 12. The INCO design, introduced in 1983, utilizes pure oxygen and yields a gas stream that is $80 \% \mathrm{SO}_{2}$. The world wide large smelters such as Kennecott Utah copper smelter in USA, Boliden's Rönnskär smelter in Sweden, Olympic Dam in South Australia use Outokumpu's flash smelting process.

Bath smelters include the Noranda and the Mitsubishi systems. The Noranda system employs a refractory-lined cylindrical vessel to smelt a broad range of copper-bearing materials (e.g., sulfide concentrate, inerts, scraps, and recycled substances). The Noranda submerged tuyere rotatable furnace design combines the functions of roaster, smelter and partial converter-An example of the Noranda process is the Horne smelter in Rouyn-Noranda, Quebec, Canada. It has the capacity to process 850,000 tonnes of materials per year, yielding 220,000 tonnes of copper anode and 500,000 tonnes of sulphuric acid. Until the 1970s, this smelter utilized conventional copper smelting technology, which included reverberatory furnaces and Peirce-Smith converters. Upgraded in late 1990s, it is now the largest and most advanced recycling plant of its kind in North America. Another important bath smelting technology is the Mitsubishi continuous smelting and converting process. It combines roasting, smelting and converting (e.g. oxidizing) in a continuous operation enabled by three furnace units (smelting, slag cleaning, converting) 
interconnected via heated and covered launders. Two separate molten streams are generated in smelting: copper-iron-sulfide matte and slag in addition to off-gas rich in sulfur dioxide. The high-grade mattes may contain as much as $75 \sim 80 \% \mathrm{Cu}$ and up to $1 \% \mathrm{Fe}$, which is further treated by a converter (it is a furnace widely used in steel making and copper making process). The slag phase is composed of silicates enriched in iron. The off-gas is sent to acid plant for sulfuric acid production. The Falconbridge Kidd Creek copper smelter in Canada utilizes the Mitsubishi process [46].

Converter smelting. The matte generated from flash smelting furnace is then transferred to a converter where copper sulfide is oxidized to metallic copper. In a converter, oxygen-enriched air is blown into the furnace. The product of a converter is called blister copper that averages 98 99\% $\mathrm{Cu}$ and about $0.02 \sim 0.1 \% \mathrm{~S}$. The off-gas is rich of sulfur dioxide, which is sent to acid plant. There are two main types of batch converters, the Pierce-Smith (the most common) and the Hoboken system.

There are three types of continuous converter: flash converting, lance converting, and submerged tuyere converting. All three offer better control over oxygen intake than batch converters and generate concentrated sulfur dioxide, which is easily captured for acid production. The continuous flash converter uses finely ground solid matte from an Outukumpu flash furnace. This process is used in Kennecott's facility in Utah [47].

The other two continuous converters utilize liquid matte, which is thermodynamically preferable to batch conversion. The first continuous lance converter was the Mitsubishi continuous converter.

Fire refining. Fire refining is usually carried out prior to the electrolysis of copper. The fire refining is operated in either reverberatory or rotary furnaces known as anode furnaces. Through 
this step, oxygen and other impurities in the blister copper can be removed before the copper is cast into anode for electrolytic refining. The processed blister copper, also known as copper anode is cast into anode shapes. Impurities are oxidized and reported to slag phase. Precious metals are not oxidized and remain in the host metal until later recovered during electrolytic operations. The purity of copper anode varies from $99 \% \mathrm{Cu}$ to $99.6 \% \mathrm{Cu}$.

Electrolytic refining. In electrolytic refining, the copper anodes produced from fire-refining are taken to a "tank house", where they are dissolved electrolytically in acidic copper sulfate solution. This electrolyte solution usually has the composition of: $\mathrm{Cu}-40 \sim 50 \mathrm{~g} / \mathrm{L} ; \mathrm{H}_{2} \mathrm{SO}_{4}$ $170 \sim 200 \mathrm{~g} / \mathrm{L} ; \mathrm{Cl}^{-}-0.02 \sim 0.05 \mathrm{~g} / \mathrm{L}$. The produced cathode copper has a purity of $99.97 \sim 99.99 \% \mathrm{Cu}$. The insoluble anode slim is collected for the recovery of precious metals.

Pyrometallurgical processing of copper concentrates produces sulfur dioxide and particulate matter. In North America, sulfur dioxide emissions may range from $2 \mathrm{~kg} / \mathrm{t}-\mathrm{Cu}$ to $20 \mathrm{~kg} / \mathrm{t}-\mathrm{Cu}$ for a modern flash smelting furnace $\left(\mathrm{SO}_{2}\right.$ removal efficiencies of $99.9 \%$ to $\left.99 \%\right)$ and from $200 \mathrm{~kg} / \mathrm{t}$ $\mathrm{Cu}$ to $300 \mathrm{~kg} / \mathrm{t}-\mathrm{Cu}$ for a bath smelter $\left(\mathrm{SO}_{2}\right.$ removal efficiencies of about $\left.90 \%\right)$._ Particulate emissions can range from $0.1 \mathrm{~kg} / \mathrm{t}$ of copper to as high as $20 \mathrm{~kg} / \mathrm{t}$ of copper. Although copper was recovered at 22 mines operating in the United States, just 13 mines accounted for more than $99 \%$ of production. Three primary smelters, 4 electrolytic and 3 fire refineries, and 12 solvent extraction-electrowinning facilities operated during the year 2003 [41]. Because of increasing use of $\mathrm{H}_{2} \mathrm{SO}_{4}$ for the SX-EW process, the US smelters use all the $\mathrm{H}_{2} \mathrm{SO}_{4}$ they produce and also import some [39]. (In US, Phelps Dodge is the only major producer of copper using both pyroand hydro- methods. Other producers use pyro- method. Electrolytic refining of copper also consumes $\mathrm{H}_{2} \mathrm{SO}_{4}$ ). 
In Chile, the largest copper producer in the world, sulfur fixation was only about $70 \%$ as of late 1990s; more recent data are not available.

\subsubsection{Hydrometallurgical Processing}

Hydrometallurgical copper recovery is the extraction and recovery of copper from ores using aqueous solutions $[43,44,45]$. Because of this, this route is also called solution method. Oxide ores and supergene sulfide ores, i.e. ores not containing iron, can be recovered most easily by hydro-metallurgical techniques [39]. The hydrometallurgical approach basically consists of two major operation units, which are leaching and precipitation.

Leaching. In hydrometallurgical process, the leaching process extracts copper by dissolution in ammonia, sulfuric acid, or hydrochloric acid. This process can operate at atmospheric pressure or as pressure leach circuits. This method is suitable for low-grade copper ore bodies for which customary mining operations would be uneconomical, as well as for the leaching of remnant ores from abandon mines. The leaching methods include dump, heap, and vat leaching techniques, as well as underground (or in situ) leaching methods.

Dump leaching is used to recover copper from large quantities (millions of tones) of strip mine waste with a very low grade. The time required is typically measured in years. Copper recovery rates very from $30 \%$ to $70 \%$ [39].

Heap leaching is essentially the same as dump leaching, except that it is applied to oxide ores. Recovery of $70-80 \%$ is possible by heap leaching.

In vat leaching, oxide ores are crushed and placed in large concrete vats (up to 18,000 tonnes capacity), then flooded by concentrated sulfuric acid, which converts most of the copper to 
copper sulfate. Extraction of one tonne of copper from ore with a grade of $1 \%$ requires 4400 liters of $96 \%$ sulfuric acid. A vat leaching typically recovers $75 \%$ of the copper. The process is fairly rapid (hours to days).

Leaching of ores and concentrates is limited to acid-soluble ore oxides that are not associated with calcite rock that consumes acid. In practice, the process is most commonly used for leaching low-grade deposits in situ or as heaps. A variety of techniques are used to extract copper-some ore is roasted or calcified before leaching, while other ore is subjected to microbial leaching. Microbial (or bacterial) leaching is used for low-grade sulfide ores; however, this type of leaching is much slower than standard acid leaching. Its application is still in pilot scale and commercial production is reported with this method.

Precipitation or SX/EW. Once the copper is extracted into liquid phase, it can be then removed from the pregnant leachate through either precipitation (or cementation) or solvent extraction and electrowinning (SX/EX).

In cementation, once the most popular method for recovering copper from the pregnant leachate, the leachate is combined with de-tinned iron in scrap iron or cementation mill where the iron replaces the copper in the solution. The copper precipitates are removed for subsequent pyrometallurgical processing. The product of cementation is cement copper.

The leaching -cementation process has now been almost universally overtaken by solvent extraction. Agitation leaching with solvent extraction is a method to produce a relatively pure solution of copper sulfate suitable for electro-winning.

In solvent extraction, now the most popular process, an organic chemical (chelating agent) that binds copper but not impurity metals is dissolved in an organic solvent (often kerosene). The 
chemical is then mixed with the pregnant leach solution. The organic solvent is separated in a settler and stripped with concentrated sulfuric acid to produce a clean, high-grade solution of copper for electrowinning. The barren leachate (or raffinate) is sent back to the leaching system.

Electrowinning. Electrowinning is the electro-deposition of copper from the loaded electrolyte solution produced by solvent extraction, yielding refined copper metal. The electrowinning is functionally equivalent to electrolytic refining, but differs in that electrowinning uses a permanent, insoluble anode. The depleted electrolyte from electrowinning is returned to the SX plant. Excess depleted electrolyte from the SX unit is returned to the raffinate pond to be recycled into the leaching circuit. Filter clay is used to filter the electrolyte. Impurities left on the bottom of the electrowinning cells are called "anode mud". Both this anode sludge and lead anodes that are no longer usable are periodically removed from the cells and sent to lead smelting facilities for resource recovery. The electricity requirement is quite high because a comparatively high voltage is needed (3.0 volt) comparing to electro-refining. The product of the SX/EW is copper cathode with purity of $99.95 \% \sim 99.99 \mathrm{Cu}[48]$. The solvent extractionelectrowinning (SX-EW) plant flow-sheet of the Falconbridge Limited's copper operation facilities at Collahuasi in Chile is shown in Figure 10. This plant produced a total of 27,895 tonnes of copper in 2003. The SX/EW process differs from traditional electrolytic refining in that the anodes are inert $(\mathrm{Pb}-\mathrm{Sn}-\mathrm{Ca})$. The copper is deposited on the cathode, liberating oxygen and regenerating the sulfate ion as sulfuric acid. Implementation of the SX/EW process is growing and is displacing the older pyro-metallurgical approach. However, whereas the pyrometallurgical approach is a net producer of by-product sulfuric acid, the hydro-metallurgical process is a net consumer of the acid. Thus, in the long run it is likely that the two will be 
increasingly combined [39]. The SX/EW process has been used by Phelps Dodge Mining Co. in USA [49].

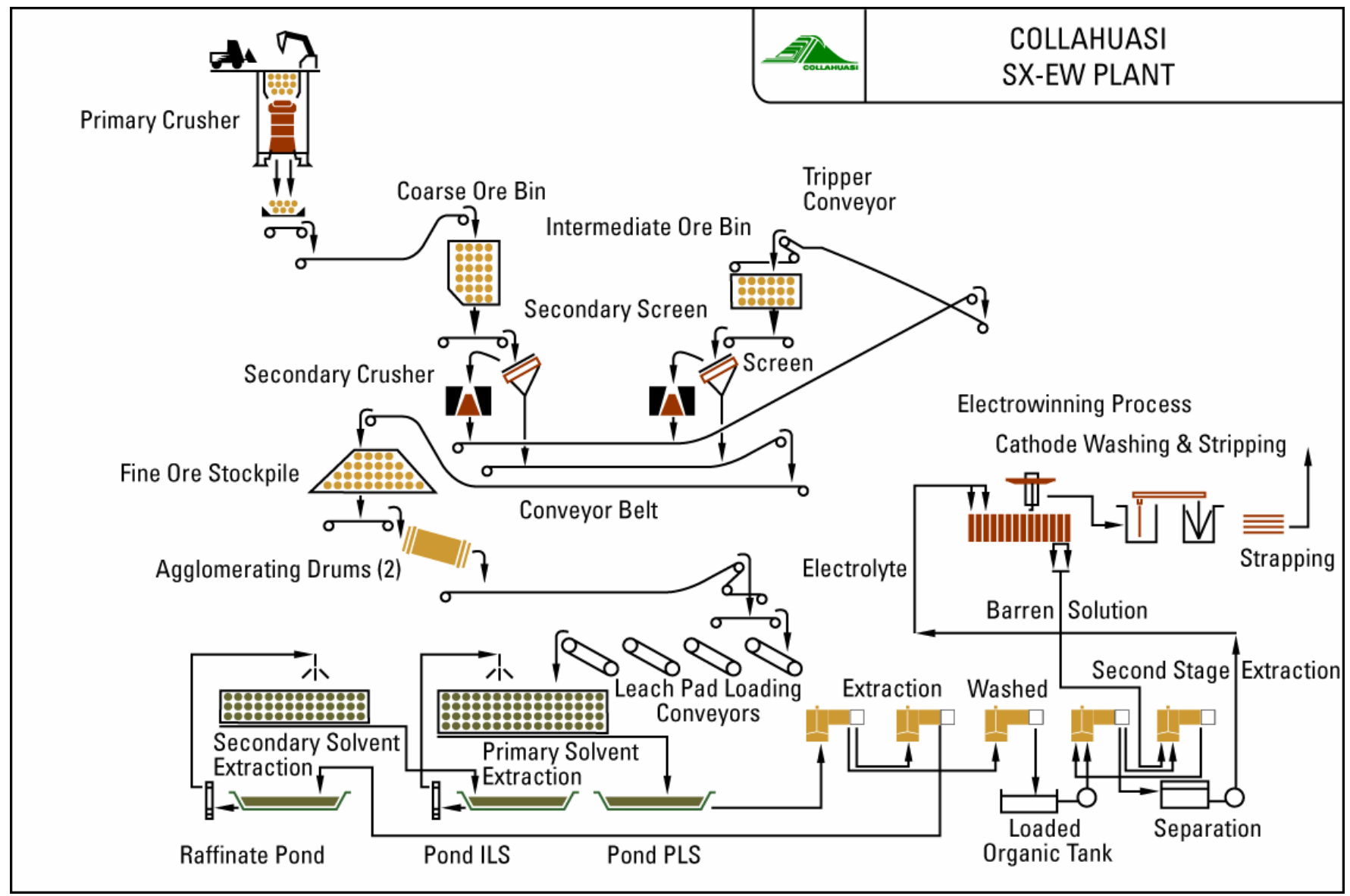

Figure 10. SX/EW plant flow-sheet of the copper operation facilities at Collahuasi in northern Chile [48]

\subsection{Selenium Production}

Selenium is a rare element widely distributed within the earth's crust, which like In, Ga and $\mathrm{Cd}$ does not occur in concentrations high enough to justify mining solely for its content. It is recovered as a byproduct, mostly from the anode slimes in the electrolytic refining of copper. An estimated 41,000 tonnes of wet copper anode slimes are generated annually, with about $17 \%$ of 
these being produced at refineries without equipment for processing them [50]. Slimes resulting from primary metal refining can have average selenium concentrations of about $10 \%$, increasing to as high as $40 \%$ in a few cases. Coal contains an average of $1.5 \mathrm{ppm}$ of selenium, which is about 80 times the average of copper deposits, but recovery of selenium from coal appears unlikely in the foreseeable future because of the high volatility of the element [51].

About 250 tonnes of secondary selenium is produced every year worldwide. This represents about $15 \%$ of refined selenium production coming from secondary sources. World refinery production of primary selenium (excluding U.S. production) increased less than $1 \%$ to 1,480 tonnes in 2002. Japanese output, which accounted for approximately $50 \%$ of the world total, is reported to have increased by $1 \%$ to 740 tonnes. Belgium, Canada, Japan, and the United States represent over $80 \%$ of the total world refinery production of selenium and tellurium [50].

In the United States, only one domestic copper refinery recovers and produces high-purity selenium (99.999\%)-ASARCO Incorporated, Amarillo, TX. One domestic producer exported semi-refined selenium ( $90 \%$ selenium content) for refining in Asia. Three other companies generated selenium-containing slimes, but did not produce selenium. Selenium-containing slimes from these refineries were exported for processing.

In Canada, primary selenium is recovered as a by-product from copper refining from two smelters. Noranda Metallurgy Inc. produces commercial and high-purity selenium at its CCR refinery in Montréal, and Inco Limited produces crude selenium at its Copper Cliff copper refinery in Sudbury.

Selenium is present in the anode slimes of electrolytic copper refining, which are those constituents in the copper anodes that are not solubilized during the electrolytic refining process and accumulate at the bottom of the electro-refining tank [52]. These slimes contain $\sim 10 \%$ 
selenium and $\sim 5 \%$ tellurium. The slimes contain $25-70 \%$ of the selenium content of the copper ore; the rest vaporizes during smelting [53]. The slimes are treated primarily for value of the precious metals gold, silver, platinum, palladium, and rhodium they contain. The recovery of selenium is a secondary priority [52].

Two major processes of extracting selenium from copper refinery slime include roasting with soda ash and roasting with sulfuric acid (Outokumpu Oy Process). Other methods include wet chlorination, oxidative leaching with sodium hydroxide solution under pressure, hydrometallurgical process of chlorination in hydrochloric acid, etc [52, 53].

Soda ash roasting is a traditional method to recover selenium and tellurium commercially. With aeration, soda ash is used to convert selenium and tellurium into a +6 oxidation state. Electrolytic copper refinery slimes are intensely mixed with soda ash binder, or sodium carbonate, and water to form a paste, which then pelletized [52]. The pellets are roasted at roasting at $530-650{ }^{\circ} \mathrm{C}$, are ground into powder and leached in water to dissolve sodium selenate. Sodium tellurate is insoluble in the alkaline leaching solution, so it is separated from the selenate with filtration. The tellurate-bearing residue is treated separately.

Recovery of selenium from the sodium selenate solution can be accomplished in two ways. First, the selenate is crystallized from solution [53]. Then charcoal, or carbon, is added to the crystalline hexavalent sodium selenate, and after mixing, heating and drying, it is reduced to sodium selenide. The dry sodium selenide is leached with water and filtered to form a concentrated solution of sodium selenide. The selenide is oxidized as air is blown through the solution to get selenium slurry. Again precipitation occurs in which much of the solution could be recycled back into the process. The precipitate undergoes melting and shotting before 
selenium metals is attained. Shotting refers to "passing molten metal through a sieve and dropping particles into water [54]" (Figure 11).

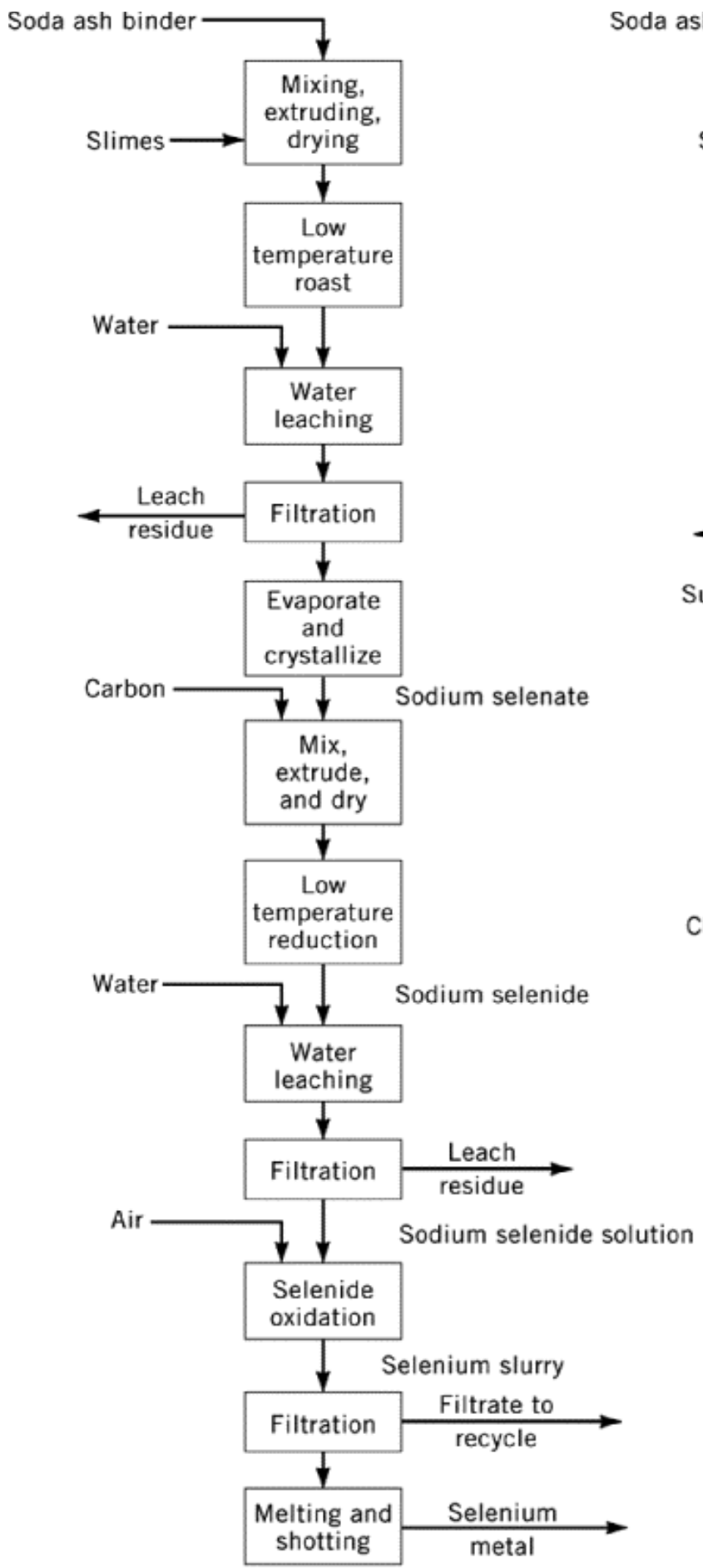

(a)

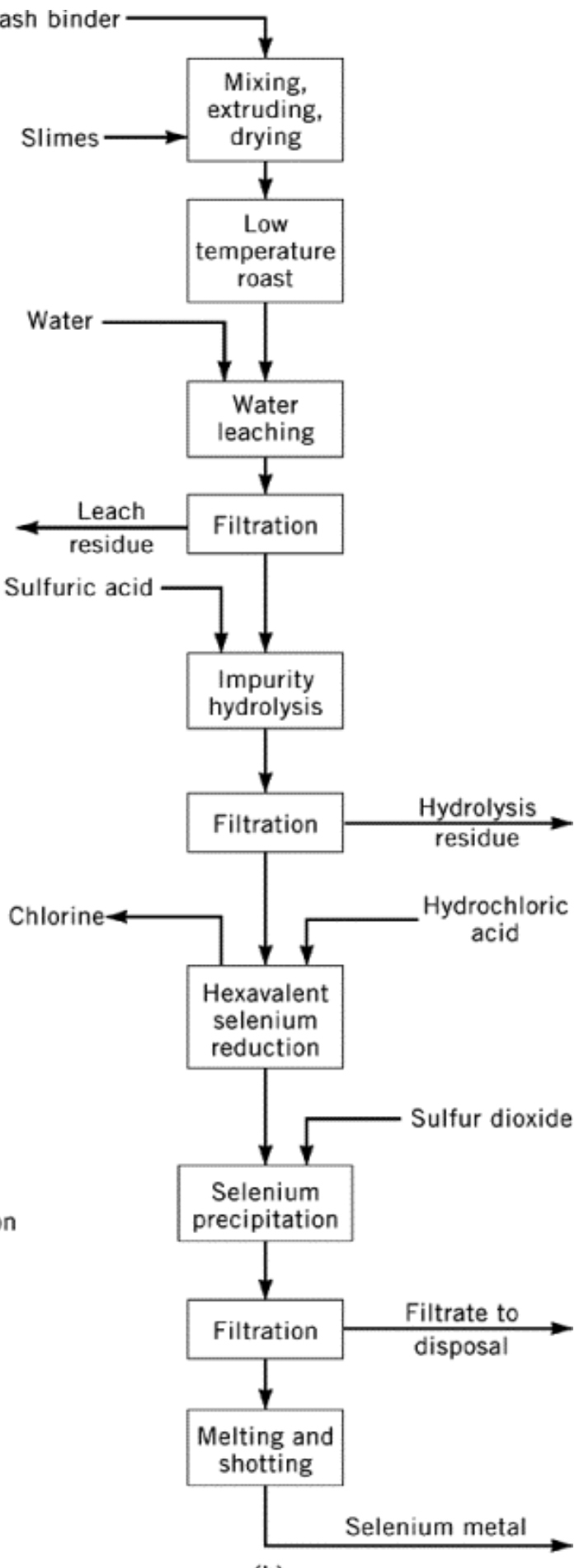

(b)

Figure 11 Recovery of selenium by soda ash or sodium carbonate roasting of slime [54] 
The second path uses sulfuric acid to remove many of the impurities in hydrolysis. Filtration occurs to remove the hydrolysis residue. Hydrochloric acid or ferrous iron salt is used for the reduction of hexavalent selenium. Iron chloride is discarded, which contain small amounts of selenium but is also extremely corrosive and creates problems for disposal. The remaining solution is precipitated with sulfur dioxide and then filtrated. Similarly, the final steps are melting and shotting to produce selenium metal (see Figure 11).

Another important recovery process is the Outokumpu process, which is practiced at Harjavalta, Finland [55]. The flowsheet of precious metal recovery at Outokumpu Harjavalta Metals Oy is shown in Figure 12. As described before, the anode slime mainly contains elements electrochemically nobler than copper ( $\mathrm{Te}, \mathrm{Se}, \mathrm{Ag}, \mathrm{Au}, \mathrm{Pt}, \mathrm{Pd})$. The slime slurry is pumped electrolysis to the Precious Metals plant.

The slime is first leached in an autoclave at $170^{\circ} \mathrm{C}$ with $6-7.5$ bar oxygen pressure in order to dissolve nickel, copper and tellurium. Tellurium is precipitated from the solution as copper telluride and sold in this form.

Selenium is recovered from the filter press cake in an electrically heated furnace where the temperature is kept at around $400-600^{\circ} \mathrm{C}$. Oxygen and $\mathrm{SO}_{2}$ gas are used as reagents. Selenium compounds react at this temperature forming gaseous selenium dioxide. The selenium dioxide gas $\left(\mathrm{SeO}_{2}(\mathrm{~g})\right)$, is sucked from the furnace through the ejector into an aqueous solution. In this solution selenium dioxide is reduced to elemental selenium by sulfur dioxide at the temperature of $80^{\circ} \mathrm{C}$. The selenium is commercial grade selenium $(>99.5 \%)$. Selenium recovery is high. The selenium content of the roasted slime is normally around $0.5 \%$. 


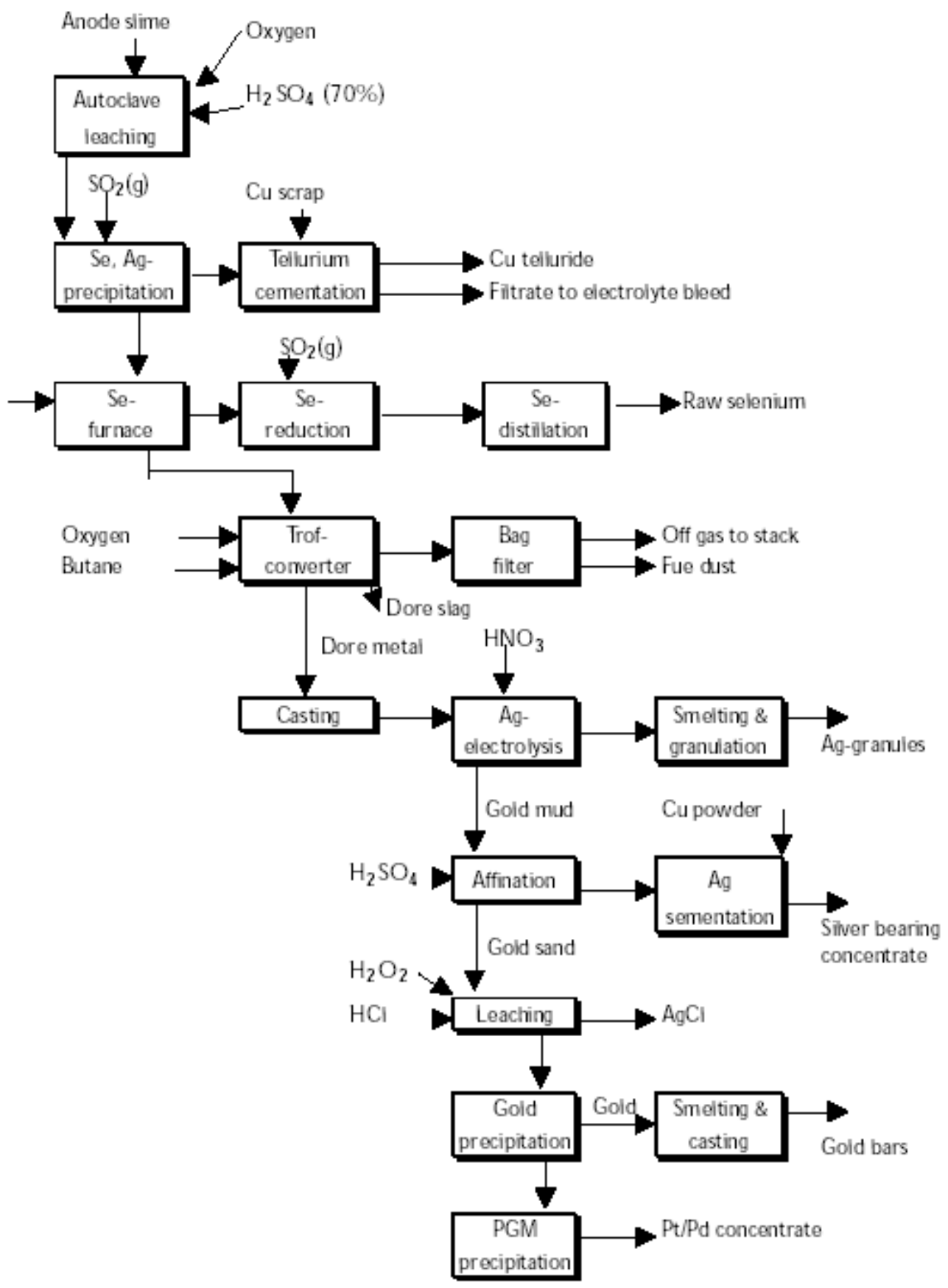

Figure 12 Recovery of selenium from copper anode slime by Outokumpu process [55]. 
Due to the fact that the roaster is furnished with gas circulation devices, it offers homogenous atmospheric conditions throughout the roaster, which leads to nearly complete removal of selenium during the process. The remaining aqueous solution is fed back to copper electrolysis. Wet chlorination process is a rapid and simple process of "obtaining high extractions of selenium from slimes [52]." In 1995, the Kennecott Utah Copper Corporation (KUCC) was the first to use wet chlorination of slimes to recover selenium and other metals. In wet chlorination, refinery slimes slurried in water or hydrochloric acid are sprayed or sprinkled with chlorine gas. In some cases, other oxidants are used such as sodium chlorate or hydrogen peroxide, which liberate chlorine from hydrochloric acid at about $100{ }^{\circ} \mathrm{C}$ [52]. Some selenium and selenide oxidizes and dissolve in the solution, but it is negligible. The main residues removed are $\mathrm{SiO}_{2}, \mathrm{BaSO}_{4}, \mathrm{PbSO}_{4}$ and $\mathrm{AgCl}$, and silver is usually recovered from it. The filtrate, which includes nickel, tin, antimony, arsenic, selenium, tellurium, gold, platinum, palladium, and bismuth, is then processed to extract the gold. Once the gold is removed, the chlorination liquor is reduced with sulfur dioxide to recover selenium and other precious metals. The acidity, temperature, and rate of reduction are carefully controlled. After the selenium is reduced, the residual solution is precipitated for precious metals. As for the selenium cake, vacuum distillation is used to recover pure selenium (see Figure 13). 


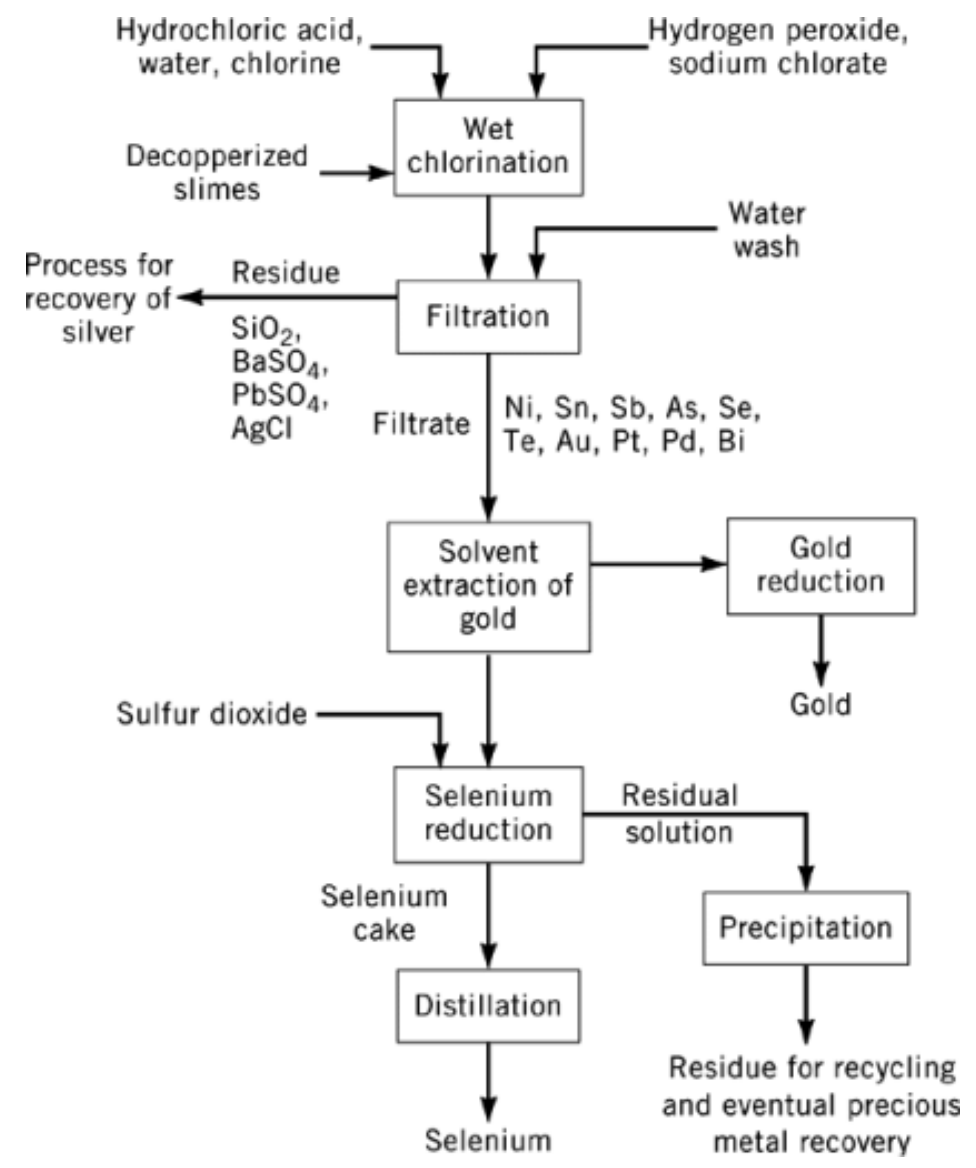

Figure 13 Recovery of selenium by wet chlorination [52]

After selenium is extracted from copper refinery slimes, the average purity of the selenium is approximately $99 \%$. For photovoltaics, a slightly higher purity of $99.99 \%$ is preferred. The simplest and the most common method of achieving $99.99 \%$ pure selenium is vacuum distillation. When distillation is performed under a vacuum, there are less emission problems, improved separation, and less corrosivity. Many of the impurities such as sulfur dioxide, water, organic matter, halogens, sulfuric acid, and mercury are all sent to a scrubber. 
During the distillation, "all the nonvolatile elements, such as copper, nickel, iron, and tellurium remain in the distillation vessel. However, sulfur and mercury also distill over and are thus not removed [53].” Therefore, crude selenium is free of mercury and many other impurities.

There are two other methods of purifying crude selenium. First is to vaporize the selenium with oxygen to form selenium dioxide, which could be absorbed in pure water. "Mercury can be removed from the solution by adsorption, and the other metallic ions by ion exchangers. Elemental selenium is then precipitated with high-purity sulfur dioxide [53]" to achieve a purity of $>99.99 \%$. Second is to dissolve the selenium in sodium sulfite, and filter it. Many impurities will not dissolve and will be filtered out, while the remaining filtrate "is acidified with sulfuric acid to precipitate selenium [56]." Lastly, the selenium is distilled to remove the impurities to produce high purity selenium.

\subsection{Tellurium Production}

Tellurium is a rare metal that can be extracted as byproduct of processing copper, lead, gold, and bismuth ores. In 1982 about $90 \%$ of tellurium was recovered from the slimes formed during the electrolytic refining of copper [57]. The slimes contain copper, tellurium, selenium, and other metals. Copper typically is removed by oxidative pressure-leaching with dilute sulfuric acid at $80-160{ }^{\circ} \mathrm{C}$. This completely extracts the $\mathrm{Cu}$, and removes $50-80 \%$ of the Te according to one source [58] or more than $90 \%$ according to another [59]. The range of Te extraction is wide because its concentration in slimes varies significantly. Tellurium is recovered from solution by cementation with copper. Copper telluride is leached with caustic soda and air to produce a sodium telluride solution. The latter is used as the feed for producing commercial grade Te metal or $\mathrm{TeO}_{2}$. Both of these forms can be used in CdTe formation for solar cells. 
Asarco in the United States produces commercial-grade tellurium at its refinery complex in Amarillo mainly from two sources: copper anode slimes and lead refinery skimmings [60]. However, the production level is not available.

In Canada, primary tellurium is recovered as a by-product from copper refining. Noranda Metallurgy Inc. produces commercial and high-purity tellurium at its CCR refinery and Inco Limited produces crude tellurium at its Copper Cliff copper refinery.

\subsection{Molybdenum production}

About $50 \%$ of the global supply of molybdenum is produced as a co-product or as a byproduct of copper mining. The rest is obtained by dedicated (primary) mining. In co-product mining commercial viability is dependent upon the extraction of both molybdenite and copperbearing minerals, whereas in by-product mining molybdenite is obtained during copper recovery. Molybdenum is produced as a byproduct of copper production at the Bagdad and Sierrita Mines in Arizona (operated by Phelps Dodge Corp, as copper-molybdenum ore, concentrated with a total concentrate molybdenum production of $29,747,000 \mathrm{lbs}$ in 2003) [49] and at the Bingham Canyon Mine in Utah (operated by Kennecott Utah Copper Corporation, as copper-molybdenum ore, concentrated). Two roasting plants converted molybdenite $\left(\mathrm{MoS}_{2}\right)$ concentrate to molybdic oxide, from which intermediate products, such as ferromolybdenum, metal powder, and various chemicals, were produced. (The data shown in this section refer to the contained molybdenum in concentrate, in average, Mo 48 - $58.8 \%$ contained in unroasted concentrate).

Kennecott Utah Copper Corporation (KUCC) recovers molybdenum as a by-product at its copper concentrator. However, the production of molybdenum at KUCC fell by about $28 \%$ year on year

to 4,600 tonnes in 2003 owing to reduced ore grade. Approximately 8,180 tonnes of molybdenum are recovered each year through the flotation process at KUCC. 
At KUCC, the molybdenum is recovered in the following procedures [61]:

In copper beneficiation process, once the copper ore emerges from the concentrator as a fine powder, it's put through a series of flotations. Then chemicals and liquids are applied to the powder so that all the copper, gold, silver, and molybdenum float to the top of the flotation cells in frothy bubbles, which are skimmed off. This is done a few more times, so that finally the molybdenum disulfide is floated off.

This rough concentrate goes through its own flotation circuit, for further cleaning. At the end of the production cycle, it ends up with a high quality moly concentrate -- molybdenum disulfide, which is about $55 \%$ molybdenum.

At this point, the molybdenum disulfide concentrate is shipped to roasting facilities, which further process the concentrate into the finished product -molybdic oxide, which is sold to steel mills all over the world.

Molybdenite recovery from copper circuits at porphyry copper mines accounts for $75 \%$ of the Western and $50 \%$ of worldwide molybdenum supply. In 2003, The U.S. mine production of molybdenum concentrate was 32,000 tonnes in 2002 and 33,500 tonnes in 2003. The world's primary production of molybdenum was 121,000 tonnes in 2002, and 125,000 tonnes in 2003. [62]. Primary molybdenum production is discussed in session 6 .

\subsection{Emission Factors in the co-production of $\mathrm{Cu}$, Mo, Se and Te}

Crushing and grinding of ores in copper mines generates dust emissions at the same levels as those in mining zinc-ores (discussed in Section 3.1). Solid wastes in mining comprise the biggest solid waste contributor in the life cycle of the metals. In addition to the ore itself, a large amount of waste rock (overburden) is removed to get access to the ore, especially in surface 
mines. The ratio of overburden to concentrator mill tailings in the US is now about 1.9:1 [39]. The most serious environmental problem associated with copper mining is acid rock drainage, formerly known as acid mine drainage, and largely associated with coal mining [39].

The second largest solid waste component consists of mill tailings or gangue, which is unmineralized rock separated from the mineralized concentrate during the beneficiation process. The global average is 37 tons of waste per ton of concentrate [39].

The next stage of waste generation occurs at the smelter/converter. Smelter recovery of copper from concentrate averages $98 \%$. About $2 \%$ of the copper (and some sulfur) remains in the slag. The slag amounts to about $1.55 \mathrm{t} / \mathrm{t}$-copper assuming concentrate with a grade of $25 \%$.

Gaseous emissions generated from primary copper smelters include sulfur dioxide and particulates from the roasters, smelting furnace, and converters. Copper and iron oxides are the primary constituents of the particulate matter; other constituents include the oxides of arsenic, antimony, cadmium, lead, mercury, and zinc. There are eight copper smelters in the United States. Sulfur dioxide is recovered in the form of sulfuric acid in all but one of these smelters. Particulate emissions are treated in ESPs or combination spray/ESP systems with efficiencies of $95 \%$ to $99 \%$. The emissions from copper smelting can vary widely depending on the ore used and the abatement measures applied. we found no explicit quantification of cadmium emissions in copper smelting in the literature. Indirect estimates can be made from comparing the $\mathrm{Cd}$ concentrations in copper and lead smelters; Table 6 shows those compiled by Ayres and Simonis [63]. According to these numbers, copper smelters would produce 3.2 to 5 times lower $\mathrm{Cd}$ emissions than lead smelters. These emissions are primarily related to pyrometallurgical operations. Emissions in hydrometallurgical/electrolytic plants are likely to be negligible unless the sulfuric-acid tanks are open to the atmosphere. 
Table 6. Uncontrolled emissions from metallurgical operations [63]

\begin{tabular}{llll}
\hline Metal & Steel and foundries (ppm) & Smelt $/$ refine copper $(\mathrm{ppm})$ & Smelt $/$ refine lead $(\mathrm{ppm})$ \\
\hline Arsenic & 15.2 & 8000 (refinery $800-900)$ & \\
Cadmium & $3.5-4.0$ & $350-650$ & $1750-2100$ \\
Chromium & $6.5-7.0$ & - & - \\
Copper & $17.5-22.5$ & $2500-5000$ & - \\
Mercury & - & 26 air 1 water & 9 air 0.5 water \\
Lead & $200-300$ & $2000-5000$ (refinery 25$)$ & $20,000-23,000$ \\
Zinc & $27-370$ & $9000-11,000$ & $500-1000$ \\
\hline
\end{tabular}

Approximately, 1 tonne of sulfur is associated with each tonne of primary copper in average ore. Emissions from primary copper smelters are principally particulate matter and oxides of sulfur (SOx). Emissions are generated from the roasters, smelting furnaces, and converters. Fugitive emissions are generated during material handling operations. Copper and iron oxides are the primary constituents of the particulate matter, but other oxides such as arsenic, antimony, cadmium, lead, mercury and zinc, may also be present, along with metallic sulfates and sulfuric acid mist. Single stage electrostatic precipitators are widely used in the primary copper industry to control these particulate emissions. Because of considerable quantities of sulfur in the ores in which copper is found, significant emissions of sulfur dioxide occur from various processes associated with primary copper smelting. The traditional roasters produce emissions with an average of 1 to $4 \%$ of $\mathrm{SO}_{2}$ and 3 to $6 \%$ of the weight of the charged concentrate as particulate [64].

Primary copper smelters are a source of sulfur oxides (SOx). The typical average $\mathrm{SO}_{2}$ concentrations from various smelter units are summarized in Table 7. 
Table 7. Typical $\mathrm{SO}_{2}$ concentration in off-gas from primary copper smelters [64] (After Pacyna)

\begin{tabular}{ll}
\hline Process unit & $\mathrm{SO}$ - \\
\hline Multiple hearth roaster & $1.5-3$ \\
Fluidized bed roaster & $10-12$ \\
Reverberatory furnace & $0.5-1.5$ \\
Electric arc furnace & $4-8$ \\
Flash smelting furnace & $10-70$ \\
Continuous smelting furnace & $5-15$ \\
Pierce-Smith converter & $4-7$ \\
Hoboken converter & 8 \\
Single contact $\mathrm{H}_{2} \mathrm{SO}_{4}$ plant & $0.2-0.26$ \\
Double contact $\mathrm{H}_{2} \mathrm{SO}_{4}$ plant & 0.05 \\
\hline
\end{tabular}

Flash smelting A flash smelting process generates the highest concentrations of $\mathrm{SO}_{2}$ (e.g., $15 \%$ ) among those process routes, as the sulfide and fine coal instantly ignite and the oxidation of sulfur is very fast. Most of the sulfur dioxide is used to produce sulfuric acid plants. Usually, the sulfur dioxide fixation percentage can be as high as $99 \%$ or above for flash smelting process. With the adoption of flash smelting and flash converting at Kennecott Utah Copper Corporation (KUCC) in USA and the use of acid plant tail gas scrubbing at other plants (mainly in Japan) sulfur capture has exceeded $99.9 \%$. The sulfur dioxide emission at KUCC's copper smelter is reportedly below $3.8 \mathrm{~kg}-\mathrm{SO}_{2} / \mathrm{t}-\mathrm{Cu}[47]$.

By-product sulfur-mainly from copper smelters- is already a significant share of global elemental sulfur supply (around 19\%) and will continue to be important for the next few decades.

Sulfur can be fixed in metallurgical processes by either: sulfuric acid production, gas scrubbing and gypsum production, liquid sulfur dioxide manufacture, or elemental sulfur production 
Sulfuric acid production is the most widely used process because is the least expensive and the market for sulfuric acid is larger than for the other products in many locations.

The Sumitomo Toyo smelter in Japan uses the traditional Outokumpu flash smelting process and Peirce-Smith converters. It has distinct differences from other smelters around the world that use that same technology. According to Toyo, it is designed to be one of the cleanest smelters in the world. The sulfur fixation at Toyo is $99.9 \%$, which is accomplished with fugitive gas collection, automated charging of converters and tail gas scrubbing. At the Toyo copper smelter, the sulfur distribution is as of: $\mathrm{H}_{2} \mathrm{SO}_{4} 95.8 \%$; gypsum $2.9 \%$; slag $1.1 \%$; water treatment $0.1 \%$; emission $0.1 \%[55]$.

Modern smelters achieve high sulfur fixation through using flash smelting technology with the integrated acid plant of double contact adsorption technique. This has been well demonstrated by KUCC in USA. Before 1993, the total $\mathrm{SO}_{2}$ emission from KUCC's smelter was as high as $\sim 110 \mathrm{~kg} \mathrm{SO}_{2} /$ tonne-Cu (By 1990, Kennecott's acid plants recovered about $93 \%$ of the sulfur). The new KUCC's smelter, started in 1995 , is designed to recover $99.9 \%$ of the sulfur produced [65]. The copper concentrate is smelted in an Outokumpu flash smelting furnace. Matte is granulated and processed using a Kennecott-Outokumpu flash converting furnace. To achieve a sulfur capture in excess of $99.9 \%$, the design incorporates the following: Continuous processes for the production of copper matte and blister copper, elimination of ladle transfers of molten metal, secondary gas collection at tapping and other furnace locations, secondary gas scrubbing, concentrate dryer off-gas scrubbing, anode furnace off-gas scrubbing and an acid plant designed to treat a feed of $14 \%$ sulfur dioxide down to less than $100 \mathrm{ppm}$ sulfur dioxide [47]. A sulfur capture of $99.9 \%$ is equal to $2 \mathrm{~kg}$ of $\mathrm{SO}_{2}$ per tonne of copper produced. It is one of cleanest copper smelters in the world. 
At KUCC, molybdenum is recovered as a by-product of the copper processing operations at its copper concentrator. Normally, approximately 8,180 tonnes of molybdenum are recovered each year through the flotation process.

\section{Emission allocation factors of molybdenum as by-product of copper}

KUCC reported that, normally, its refined copper production level is 300,000 tons $(272,156$ tonnes) of copper and approximately 18 million pounds (8,172 tonnes) of molybdenum annually. Based on this information, we can calculate the allocation factor of $\mathrm{Mo} / \mathrm{Cu}$ as: $3 \%$. However, due to the reduced molybdenum ore grade, the KUCC produced less and less tonnes of molybdenum in the last few years as shown in table 8.

Table 8. Cu and Mo production level at KUCC, USA [47]

\begin{tabular}{llll}
\hline Year & $\mathrm{Cu}$, tonne & $\mathrm{Mo}$, tonne & $\mathrm{Mo} / \mathrm{Cu}, \%$ \\
\hline 2001 & 312,668 & 8,106 & 3 \\
2002 & 293,700 & 6,100 & 2 \\
2003 & 230,600 & 4,600 & 2 \\
\hline
\end{tabular}

This gives an allocation factor of $2 \%$ in the year 2003. Summarily, prior to 2002, an allocation factor of 3\% should be applied to molybdenum. From 2002 on, an allocation factor of $2 \%$ can be used.

The Olympic Dam smelter in Australia also uses flash smelting technology [66]. The emission factors for $\mathrm{SO}_{2}$ of these two smelters are listed in table 9. In 2003, the Olympic Dam smelter achieved sulfur dioxide fixation of $99.4 \%$, which gave an emission level of $15 \mathrm{~kg}-$ $\mathrm{SO}_{2} /$ tonne-Cu. As shown in this table, the emissions of $\mathrm{SO}_{2}$ generated from KUCC's modernized flash smelting furnace are lower than those from the Olympic Dam smelters. 
Table 9. The $\mathrm{SO}_{2}$ emissions from flash smelting furnaces

\begin{tabular}{|c|c|c|c|c|c|c|}
\hline Year & 1999 & 2000 & 2001 & 2002 & \multicolumn{2}{|c|}{2003} \\
\hline $\begin{array}{l}\text { Olympic } \\
\text { Australia }^{1}\end{array}$ & \multicolumn{6}{|c|}{$\begin{array}{l}\text { Flash smelting-electric slag cleaning furnace, electro-static precipitator } \\
\text { device, by products-gold, silver }\end{array}$} \\
\hline $\begin{array}{l}\text { Copper } \\
\text { produced(tonnes) }\end{array}$ & 138,272 & 200,423 & 200,523 & 178,120 & \multicolumn{2}{|c|}{160,079} \\
\hline Gold, kg & 854 & 1,959 & 3,176 & 1,800 & \multicolumn{2}{|c|}{2,411} \\
\hline Silver, $\mathrm{kg}$ & 6,862 & 17,504 & 25,560 & 18,030 & \multicolumn{2}{|c|}{16,839} \\
\hline $\begin{array}{l}\text { Uranium oxide, } \\
\text { tonnes }\end{array}$ & 3,221 & 4,539 & 4,379 & 2,890 & \multicolumn{2}{|c|}{3,203} \\
\hline $\begin{array}{l}\text { Total } \mathrm{SO}_{2} \text { emissions, } \\
\text { tonnes }\end{array}$ & 2,636 & 3,859 & 3,518 & 2,791 & \multicolumn{2}{|c|}{2,408} \\
\hline $\begin{array}{l}\mathrm{kg} \text { of } \mathrm{SO}_{2} / \text { tonne- } \mathrm{Cu} \\
\text { produced }\end{array}$ & 19.1 & 19.3 & 17.5 & 15.7 & \multicolumn{2}{|l|}{15.0} \\
\hline $\begin{array}{l}\text { Energy } \\
\mathrm{MJ} / \mathrm{kg}-\mathrm{Cu}, 1^{*} \text { usage, }\end{array}$ & 25 & 19 & 20 & 21 & \multicolumn{2}{|l|}{22} \\
\hline KUCC, USA $^{2}$ & \multicolumn{6}{|c|}{$\begin{array}{l}\text { Flash smelting, double-contact acid plant, by product-gold, silver, } \\
\text { molybdenum, selenium }\end{array}$} \\
\hline $\begin{array}{l}\text { Copper } \\
\text { produced(tonnes) }\end{array}$ & 286,000 & 300,000 & 312,668 & 293,700 & \multicolumn{2}{|c|}{230,600} \\
\hline Gold, tonnes & N/A & N/A & 18.352 & 15.128 & \multicolumn{2}{|c|}{9.548} \\
\hline Silver, kg & 114,700 & 124,000 & 138,725 & 125,147 & \multicolumn{2}{|c|}{91,853} \\
\hline Molybdenum, tonnes & $\sim 8,172$ & $\sim 8,172$ & 8,106 & 6,100 & \multicolumn{2}{|c|}{4,600} \\
\hline $\begin{array}{l}\text { Estimated selenium } \\
\text { production(tonnes)** }\end{array}$ & 54 & 56 & 59 & 55 & \multicolumn{2}{|l|}{43} \\
\hline $\begin{array}{l}\text { Emission of } \mathrm{SO}_{2} \text { to } \\
\text { air (tonnes) }\end{array}$ & $850^{*}$ & 849.1 & 725.8 & $647 *$ & \multicolumn{2}{|l|}{877} \\
\hline $\begin{array}{l}\mathrm{kg} \text { of } \mathrm{SO}_{2} / \text { tonne } \\
\text { metal produced } \\
*: \text { Estimated from the }\end{array}$ & $2.8^{*}$ & XUCC. & 2.3 & $2.0^{*}$ & \multicolumn{2}{|l|}{3.8} \\
\hline \multicolumn{7}{|c|}{ **: overall selenium recover percentage $75 \%$} \\
\hline \multicolumn{7}{|l|}{ Data sources: } \\
\hline 1-Environmental & Data & of & ympic & Dam, & & 2003 \\
\hline \multicolumn{7}{|c|}{ http://www.wmc.com/sustainability/sitedata/index.htm?p=CRP\&s=DTA\&d=EDT\&y=2003 } \\
\hline \multicolumn{7}{|c|}{$\begin{array}{l}1^{*} \text {-The energy usage includes electricity, natural gas, LPG and liquid fuels such as diesel and } \\
\text { petrol. }\end{array}$} \\
\hline $\begin{array}{l}\text { 2-Social\&Environmen } \\
\text { http://www.kennecott. }\end{array}$ & com/librar & $\begin{array}{l}\text { Report } \\
\text { oorts.htm }\end{array}$ & of & KUCC, & & 2003, \\
\hline
\end{tabular}


As a case study for a modern flash smelter, the emission factors for various metals in KUCC of USA are reported in Table 10.

Table 10. The emission factors for primary copper production at KUCC [42] (g/t-Cu produced)

\begin{tabular}{|c|c|c|c|c|c|}
\hline \multirow[t]{3}{*}{ Element } & Year $\rightarrow$ & 1998 & 1999 & 2000 & 2001 \\
\hline & \multicolumn{5}{|l|}{ Release type } \\
\hline & Fugitive air & 0.3 & 0.3 & 0.3 & 0.3 \\
\hline $\mathrm{Sb}$ & Stack air & 0.3 & 0.3 & 0.3 & 0.3 \\
\hline \multirow[t]{2}{*}{ compounds } & Total & 619 & 473 & 278 & 115 \\
\hline & Fugitive air & 0.3 & 0.9 & 0.9 & 0.3 \\
\hline As & Stack air & 36 & 26.4 & 27 & 2.5 \\
\hline \multirow[t]{2}{*}{ compounds } & Total & 7675 & 9420 & 7979 & 3511 \\
\hline & Fugitive air & 0.006 & 0.006 & 0.006 & 0.006 \\
\hline $\mathrm{Cd}$ & Stack air & 2.9 & 5.9 & 5.4 & 0.3 \\
\hline \multirow[t]{2}{*}{ compounds } & Total & 195 & 108 & 85 & 48 \\
\hline & Fugitive air & 0.006 & 0.006 & 0.006 & 0.006 \\
\hline $\mathrm{Cr}$ & Stack air & 0.3 & 0.3 & 0.3 & 0.3 \\
\hline \multirow[t]{2}{*}{ compounds } & Total & 235 & 298 & 5557 & 646 \\
\hline & Fugitive air & 8.8 & 7.9 & 9.12 & 4.8 \\
\hline $\mathrm{Cu}$ & Stack air & 92.4 & 66 & 132 & 63.6 \\
\hline \multirow[t]{2}{*}{ compounds } & Total & 27320 & 10103 & 37279 & 17361 \\
\hline & Fugitive air & 1.4 & 3.7 & 2.9 & 0.72 \\
\hline $\mathrm{Pb}$ & Stack air & 100 & 101 & 61.2 & 4.4 \\
\hline \multirow[t]{2}{*}{ compounds } & Total & 6538 & 5789 & 4747 & 3459 \\
\hline & Fugitive air & 0.006 & 0.006 & 0.00004 & 0.00004 \\
\hline $\mathrm{Hg}$ & Stack air & 0.006 & 0.006 & 0.04 & 0.02 \\
\hline \multirow[t]{2}{*}{ compounds } & Total & 3 & 7 & 8 & 8 \\
\hline & Fugitive air & 0.3 & 0.3 & 0.3 & 0.3 \\
\hline $\mathrm{Se}$ & Stack air & 0.9 & 0.9 & 0.9 & 0.3 \\
\hline \multirow[t]{2}{*}{ compounds } & Total & 248 & 184 & 156 & 165 \\
\hline & Fugitive air & 1.4 & 1.4 & 1.4 & 1.4 \\
\hline
\end{tabular}




\begin{tabular}{|c|c|c|c|c|c|}
\hline \multirow[t]{3}{*}{$\mathrm{H}_{2} \mathrm{SO}_{4}$} & Stack air & 120 & 37.2 & 33.6 & 34.8 \\
\hline & Total & 121 & 39 & 35 & 36 \\
\hline & Fugitive air & 0.006 & 0.006 & 0.006 & 0.006 \\
\hline \multirow[t]{3}{*}{$\mathrm{Tl}$ compounds } & Stack air & 0.9 & 0.3 & 4 & 0.3 \\
\hline & Total & 470 & 278 & 150 & 70 \\
\hline & Fugitive air & 0.3 & 0.3 & 0.3 & 0.3 \\
\hline $\mathrm{Zn}$ & Stack air & 6.1 & 4.7 & 16.8 & 0.9 \\
\hline compounds & Total & 8865 & 6898 & 6703 & 6280 \\
\hline \multicolumn{6}{|c|}{$\begin{array}{l}\text { Annotation: total emissions include released to air; water; and land } \\
\text { Source: Environmental Release Report: Kennecott Utah Copper Smelter \& Refy. } 2002 \text { TRI } \\
\text { Pollution Releases, Scorecard, } \\
\text { http://www.scorecard.org/env-releases/facility.tcl?tri id=84006KNNCT8362W } \\
\text { Units in g/tonne-Cu produced unless specified }\end{array}$} \\
\hline
\end{tabular}

At KUCC, in 2003, total $\mathrm{SO}_{2}$ emissions from the smelter were 966.8 tons, which means that 965,833 tons of $\mathrm{SO}_{2}$ were captured by the pollution control equipment-the double contact acid plant. Of the total $\mathrm{SO}_{2}$ emissions from KUCC's operations, the smelter represented approximately $27 \%$, while the remaining sulfur dioxide emissions from operations largely result from fuel usage in the power plant $(71 \%)$, while $\mathrm{SO}_{2}$ emissions from the mine mobile equipment were minimal (.01\%) [67].

The KUCC's low $\mathrm{SO}_{2}$ emission is accomplished by: continuous processes for the production of copper matte and blister copper, elimination of ladle transfers of molten metal, secondary gas collection at tapping and other furnace locations, secondary gas scrubbing, concentrate dryer offgas scrubbing, anode furnace off-gas scrubbing and double contact acid plant [47]

In Europe, Boliden's Rönnskär smelter in northern Sweden extracts base metals and byproducts from concentrates and recycled raw materials [68]. Rönnskär is one of the world's largest facilities for the recycling of base metals from electronic scrap as well as other secondary raw materials. The major products of Rönnskär are copper, lead, gold, silver and zinc clinker. It 
also produces crude selenium ( $95 \%$ selenium) as well as copper telluride (33\% copper, $35 \%$ tellurium and $6 \%$ silver) in the process at the precious metals plant. The portion of total metal production derived from recycling was $20 \%$ for copper, $40 \%$ for gold and $90 \%$ for zinc. Copper concentrate is processed using flash smelting technology. The sulfur at Rönnskär is recovered as sulfuric acid and liquid sulfur dioxide. It is reported that the fixation of sulfur dioxide exceeded $99 \%$. In the precious metals plant, Kaldo furnace is used to process and recover selenium. The metals' production levels in 2002 and 2004 are reported in Table 11.

Table 11. Primary metals and by-products levels at Rönnskär (Tonnes)

\begin{tabular}{llllllllll}
\hline Year & $\mathrm{Cu}$ & $\mathrm{Pb}$ & $\mathrm{Au}$ & $\mathrm{Ag}$ & Zinc clinker & Sulfuric acid & $\mathrm{Liquid}_{\mathrm{SO}}$ & $\mathrm{Te}^{*}$ & $\mathrm{Se}^{* *}$ \\
\hline 2002 & 224,400 & 17,700 & 15.6 & 408 & 34,400 & 544,000 & 54,700 & 13 & 34 \\
2004 & 230,000 & 30,000 & 15 & 475 & 40,000 & 600,000 & 50,000 & 14 & 35 \\
*, Tellurium production is estimated using an allocation factor of $0.010 \% \mathrm{Te} / \mathrm{Cu}$-cathode & \\
**, Selenium production is estimated using an allocation factor of $0.025 \% \mathrm{Se} / \mathrm{Cu}$-cathode \\
Assumption- 80\% of total copper production is from concentrate and 20\% is from recycled material \\
The total recovery percentage of selenium and Tellurium is assumed as 75\% respectively \\
Data sources: http://www.boliden.com/
\end{tabular}

The emissions quantities for 2001 and 2002 of this smelter are listed in Table 12. It was calculated that the emission of $\mathrm{SO}_{2}$ of 2002 was $18.5 \mathrm{~kg}-\mathrm{SO}_{2} /$ tonnes- $\mathrm{Cu}$, which is in the same level as the emissions of the Olympic Dam smelter in Australia.

Table 12. The emission data from the copper smelter at Boliden's Rönnskär, Sweden ${ }^{*}$

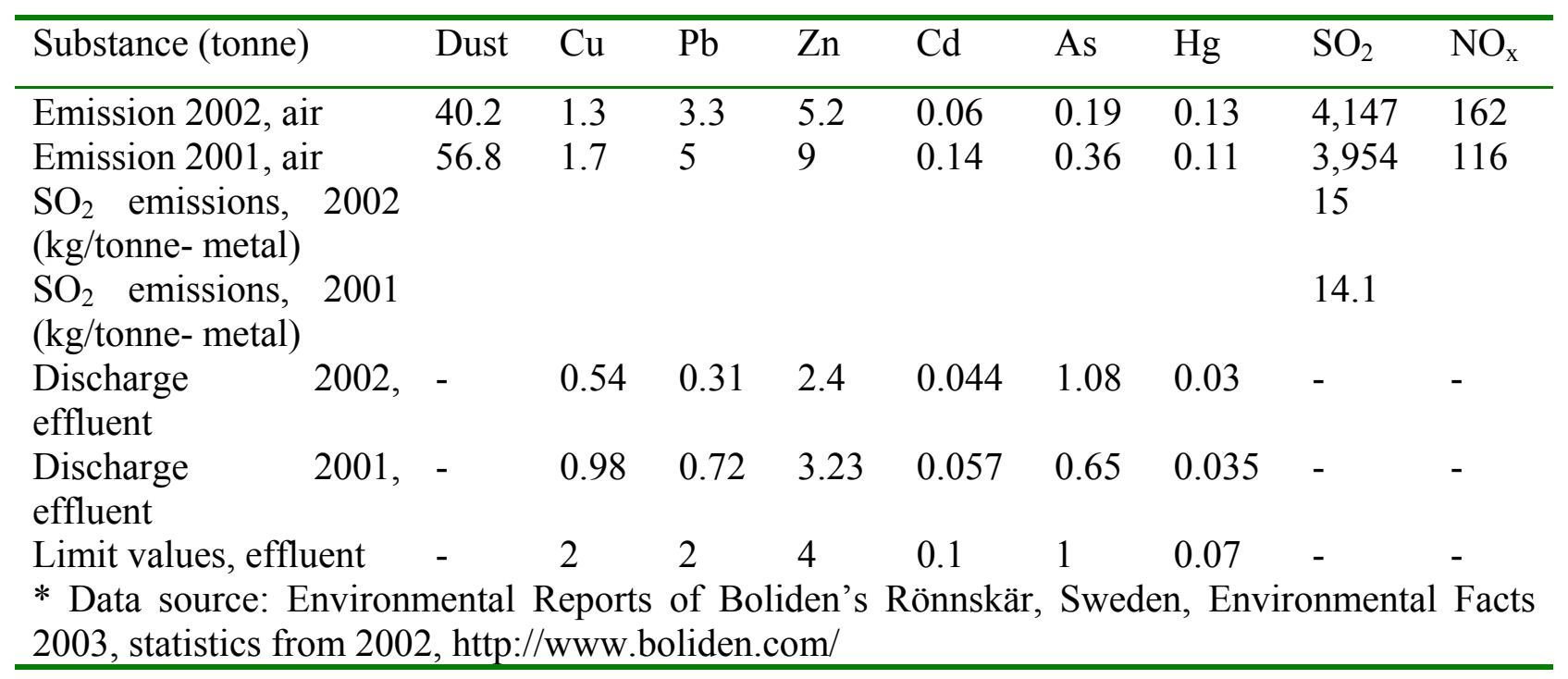


Summarily, in flash smelting operations, sulfur dioxide fixation percentage can be as high as $99 \%$ and even better.

\section{$\underline{\text { Mitsubishi smelting process }}$}

This process is used in Falconbridge Limited, Kidd Metallurgical Division. Its copper smelter consists of three furnaces (smelting, slag cleaning, converting), interconnected by gravity flow launders. Electrostatic precipitators and scrubbers are used in this plant. The acid plant is a double-contact, double adsorption plant with a design conversion efficiency of $99.5 \%$. The gas effluents contain about $10 \%$ of sulfur dioxide, a large fraction of which is recovered as liquid sulfur dioxide. As shown in Table 4 of section 3.7, the sulfur dioxide emission is controlled below $20 \mathrm{~kg}-\mathrm{SO}_{2} /$ tonne-metal in this plant.

\section{Bath smelting}

Traditional copper smelters usually have much higher emission of sulfur dioxide due to the difficulty of recovering sulfur dioxide associated with the use of reverberatory furnaces. Consequently, without acid plants to treat sulfur dioxide, the emission factor of $\mathrm{SO}_{2}$ can be as high as $1000 \mathrm{~kg}-\mathrm{SO}_{2} /$ Tonne-Cu. Noranda's Horne smelter utilizes bath smelting technology. It processes copper concentrates, copper and precious metal-bearing recyclable materials and other complex, high-margin material. This smelter produces copper anodes of $99.1 \% \mathrm{Cu}$. The smelter (bath smelting process) had $\mathrm{SO}_{2}$ emission levels of 552,000 tonnes in 1980 and 420,000 tonnes in 1988 before a sulfuric acid plant in services in 1989. The emission levels of $\mathrm{SO}_{2}$ at Horne smelter are listed in table 13. 
Table 13 Energy consumption and $\mathrm{SO}_{2}$ emission levels at the Horne smelter(bath smelting) in Canada [69]

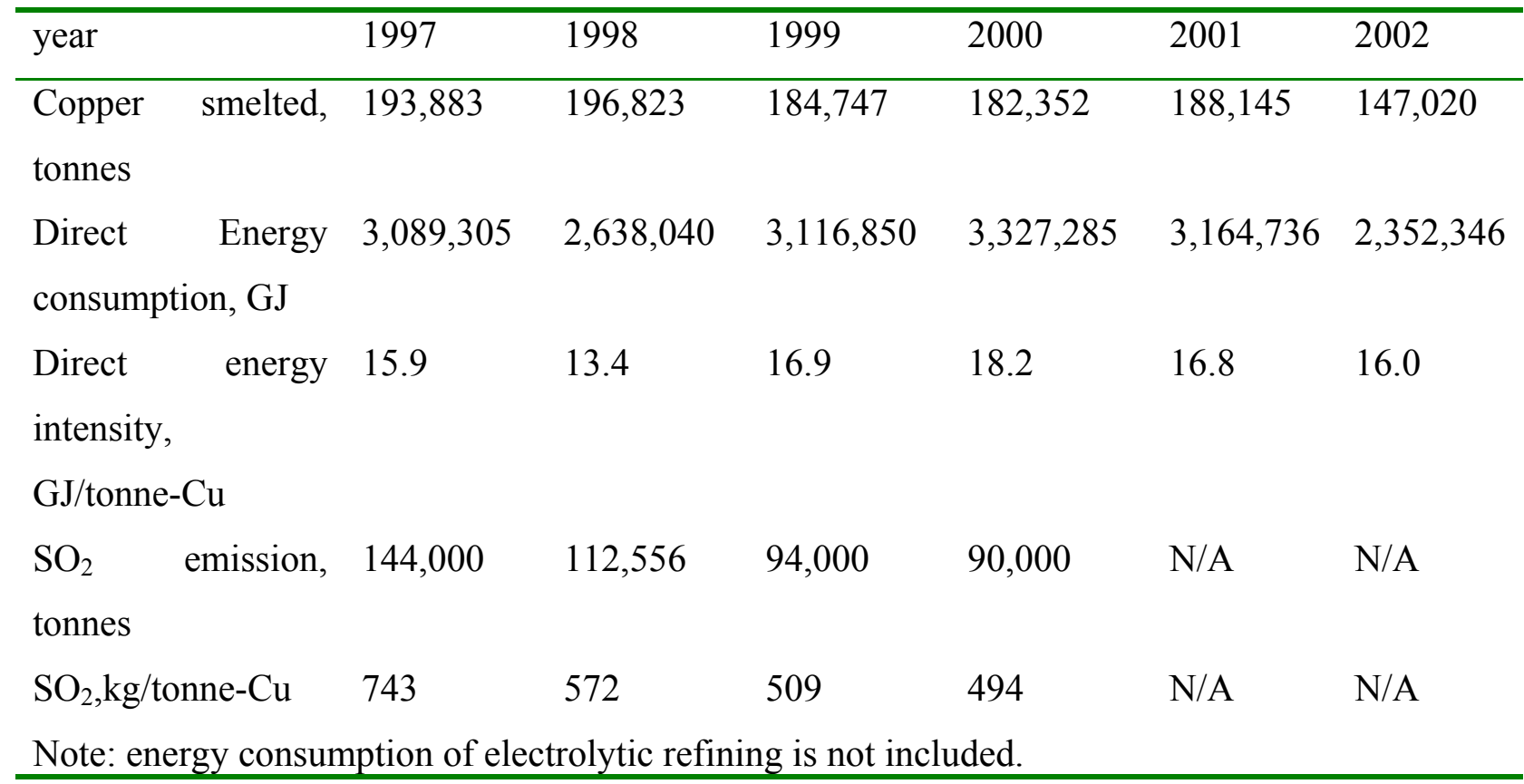

As seen from the above table, the $\mathrm{SO}_{2}$ emission is much higher compared to flash smelting. The Noranda's facilities in Canada are one the world's largest producers of zinc, nickel and copper. The copper is produced using a bath smelting technology. The average emission factors from Noranda's smelters in Canada are listed in Table 14.

Table 14 Emissions of $\mathrm{SO}_{2}$ from Noranda/Falconbridge's smelters

\begin{tabular}{lllll}
\hline Environmental data of Noranda & 2000 & 2001 & 2002 & 2003 \\
\hline Total metal production (including $\mathrm{Cu}, \mathrm{Zn}, \mathrm{Ni}$, & $1,302,922$ & $1,346,348$ & $1,346,229$ & $1,267,765$ \\
$\mathrm{Co}, \mathrm{Pb}$, and $\mathrm{Al}$ ) (tonnes) & & & & \\
Refined copper produced (tonnes) & 487,285 & 528,451 & 507,392 & 491,963 \\
Refined zinc produced (tonnes) & 405,097 & 405,598 & 416,384 & 361,989 \\
Recycled metal processed (tonnes) & 186,052 & 148,579 & 110,864 & 142,004 \\
$\mathrm{SO}_{2}$ emissions (tonnes) & 221,497 & 228,973 & 178,074 & 143,487 \\
$\mathrm{SO}_{2}$ emission factors (kg/tonne- metal) & 170 & 160 & 110 & 113 \\
\hline
\end{tabular}




\begin{tabular}{|c|c|c|c|c|}
\hline Metal emissions to air (tonnes) & 638 & 1,005 & 866 & 1,009 \\
\hline Metals released to water (tonnes) & 65 & 69 & 37 & 47 \\
\hline $\begin{array}{l}\text { Total greenhouse gas emission (tonnes } \mathrm{CO}_{2-} \\
\text { eq) }\end{array}$ & 6,215 & 6,647 & 6,349 & 6,862 \\
\hline Energy Intensity, $\mathrm{GJ} /$-tonne refined $\mathrm{Cu}$ & $\mathrm{N} / \mathrm{A}$ & 22.77 & 21.73 & 20.63 \\
\hline Energy Intensity, GJ/-tonne refined Zn & $\mathrm{N} / \mathrm{A}$ & 26.82 & 26.96 & 28.66 \\
\hline
\end{tabular}

Data source: Sustainable Development Reports of Noranda Inc./Falconbridge Limited, 2003 and 2002 Sustainable Development Reports, http://www.noranda.com

Note: sulfur dioxide and copper produced from the Gaspé Smelter, Horne Smelter, Kidd Metallurgical and Altonorte Smelter.

Apparently, as can be seen from above tables, the $\mathrm{SO}_{2}$ emission from a bath smelter is much higher than that of from flash smelting smelter. $82.6 \%$ of sulfur fixation was achieved in 2003 in Noranda's smelters. Its target is for its Canadian operations to achieve $90 \%$ capture of sulfur, a 57\% reduction from the 1985 release level. Compared to $99 \%$ sulfur dioxide fixation of flash smelting, the bath smelting has only around $90 \%$ of sulfur dioxide fixation.

\section{Emissions from electrolytic refining of copper}

To produce copper cathode, an electrolytic refining process is involved. The electrolytic refining does not produce emissions to atmosphere unless the associated sulfuric acid tanks are open to the atmosphere. However, spent electrolyte and wash water contain significant amount of metal compounds in solution and usually need to be treated prior to discharge. The Canadian Copper Refinery (CCR) of Noranda processes copper anodes from the Horne and Altonorte smelters as well as secondary feed from other third-party sources. Along with the production of copper cathode, the CCR produces gold, silver, platinum/palladium concentrate, selenium and tellurium. In 2003 , this refinery produced 235000 tonnes of copper cathode, approximately 1.1 million 
ounces of gold, 30.3 million ounces of silver and other by-products. As a typical electrolytic copper refinery, its energy consumption and emission levels are listed in table 15.

Table 15. Energy consumption and emissions in a typical copper electrolytic refinery (CCR of

$$
\text { Canada) }[69,70]
$$

\begin{tabular}{|c|c|c|c|c|c|c|c|}
\hline Year & 1997 & 1998 & 1999 & 2000 & 2001 & 2002 & 2003 \\
\hline $\begin{array}{l}\text { Copper } \\
\text { cathode } \\
\text { production, } \\
\text { tonnes }\end{array}$ & 339,616 & 324,230 & 310,608 & 313,412 & 323,023 & 244,252 & 235,425 \\
\hline $\begin{array}{l}\text { Gold refined, } \\
\mathrm{kg}\end{array}$ & 29,624 & 30,716 & 33,656 & 31,416 & 34,608 & 28,84 & 31,696 \\
\hline $\begin{array}{l}\text { Silver } \\
\text { refined, } \mathrm{kg}\end{array}$ & 890,624 & 1049,832 & $1,158,892$ & $1,242,836$ & $1,202,404$ & $1,132,292$ & 848,708 \\
\hline $\begin{array}{l}\text { Selenium } \\
\text { production, } \\
\text { tonnes }^{*}\end{array}$ & 256 & 244 & 234 & 236 & 243 & 184 & 177 \\
\hline $\begin{array}{l}\text { Tellurium } \\
\text { production, } \\
\text { tonnes** }\end{array}$ & 26 & 24 & 23 & 24 & 24 & 18 & 18 \\
\hline $\begin{array}{l}\text { Total direct } \\
\text { energy } \\
\text { consumption, } \\
\text { GJ }\end{array}$ & $2,421,876$ & $2,625,640$ & $2,633,966$ & $2,450,801$ & $2,114,905$ & $1,916,860$ & N/A \\
\hline $\begin{array}{l}\text { Energy } \\
\text { efficiency, } \\
\mathrm{GJ} / \text { tonne-Cu }\end{array}$ & 7 & 8 & 8 & 8 & 7 & 8 & N/A \\
\hline $\begin{array}{l}\text { Total } \\
\text { Particulate }\end{array}$ & 32.9 & 36.53 & 39 & 47 & N/A & N/A & N/A \\
\hline
\end{tabular}


pyro-metallurgical process. In general, the SEC of hydrometallurgical technologies is higher than that of pyro-metallurgical processes $[72,73]$. The breakdown of the SEC by process operations is approximately as follows: open-pit mining, $20 \%$; concentration, $50 \%$; smelting, $17 \%$; refining, $13 \%$.

The reported energy consumption as of 1992 from the production of 1 tonne of copper from concentrate and scrap in Germany was $21.8 \mathrm{GJ} /$ tonne, which was split as: $6.3 \mathrm{GJ} /$ tonne for the production only and $15.5 \mathrm{GJ} /$ tonne attributed to the electricity and other. The same author also reported that the energy consumption for the production of 1 tonne of copper from secondary materials was split as: $9.21 \mathrm{GJ} /$ Tonne for the production only, and $11.34 \mathrm{GJ} /$ tonne for the electricity and other [74].

Yet, another study reported that the energy consumption in the production of copper is as follows [75]: mining- $23.4 \mathrm{GJ} /$ tonne- $\mathrm{Cu}$; ore preparation-39.3 GJ/tonne- $\mathrm{Cu}$; smelting-95.5 $\mathrm{GJ} /$ tonne- $\mathrm{Cu}$, casting and finishing-5.4 GJ/tonne-Cu. The same study also estimated that total minimum energy consumption is $51.7 \mathrm{GJ} /$ tonne- $\mathrm{Cu}$, and the maximum energy consumption is 179.7 GJ/tonne-Cu [75].

The energy consumption at the KUCC smelter was reported to be 67.9 million BTUs per short ton of cathode (75.4 GJ/tonne-Cu), in 2003. For 2004, its target for energy consumption is 56.3 million BTUs per short ton of cathode production $(62.6 \mathrm{GJ} /$ tonne-Cu$)$. This energy consumption includes fuel burned (coal, diesel, natural gas, gasoline, and propane) on site, fuel used to generate electricity, and purchased electricity [67].

When using these data, we need to assume the electricity generation efficiency of $35 \%$. The electric power requirements are assumed to be $6000 \mathrm{~kW} / \mathrm{t}$ (21.6 GJ-eq/tonne) for the flash smelter, $5700 \mathrm{~kW} / \mathrm{t}(20.52 \mathrm{GJ}-\mathrm{eq} / \mathrm{tonne})$ for the reverberatory smelter and $9350 \mathrm{~kW} / \mathrm{t}(33.66 \mathrm{GJ}-$ 
eq/tonne) for the SX/EW plant. The flash furnace recovers $93 \%$ of sulfur dioxide as sulfuric acid. In case of reverberatory furnace, only $5 \%$ of sulfur dioxide is recovered [39].

Table 16. Electricity Consumption for copper Process Stages [76,77]

\begin{tabular}{|c|c|c|c|c|}
\hline \multirow{3}{*}{$\frac{\mathrm{Cu}}{\text { Smelting/Electro-refining route }}$} & \multicolumn{3}{|c|}{ Unit: $\mathrm{kWh} / \mathrm{t}-\mathrm{Cu}$} & \\
\hline & \multirow[b]{2}{*}{$1^{*}$} & \multirow[b]{2}{*}{$2^{* *}$} & \multicolumn{2}{|c|}{ Hydro-metallurgical route } \\
\hline & & & & $2^{* *}$ \\
\hline Mining & & 433 & Mining & 650 \\
\hline Milling & & 1233 & Crushing & 100 \\
\hline Mining and milling subtotal & \multicolumn{2}{|r|}{1666} & & $\underline{750}$ \\
\hline $0.6 \% \mathrm{Cu}$ ore & $\underline{5929}$ & $3.0 \% \overline{\mathrm{Cu}}$ ore & & $2.0 \% \overline{\mathrm{Cu}}$ ore \\
\hline $1.0 \% \mathrm{Cu}$ ore & $\underline{3556}$ & & & \\
\hline Smelting & & 430 & Leach/SX & 2500 \\
\hline Refining & & 300 & EW & 2000 \\
\hline Smelting and refining subtotal & $\underline{4178}$ & $\underline{730}$ & & \\
\hline Total & $\underline{7733}$ & $\underline{2396}$ & & $\underline{5250}$ \\
\hline \multicolumn{5}{|c|}{ Data sources: $1^{*}$-Ref. 77 , electricity generation efficiency, $32 \%$} \\
\hline \multicolumn{5}{|c|}{$2^{* *}$-Ref. 76 , electricity generation efficiency, $35 \%$} \\
\hline
\end{tabular}

It is obvious that the electricity requirements for the production of copper is quite sensitive to the original copper ore grade. For example, to produce one tonne of refined copper with ore grade of $3.0 \% \mathrm{Cu}$, the electricity consumption is assumed to be around $2396 \mathrm{kWh} / \mathrm{t}-\mathrm{Cu}(8.6 \mathrm{GJ}-\mathrm{eq} / \mathrm{tonne})$, whereas it may need $7733 \mathrm{kWh} / \mathrm{t}-\mathrm{Cu}(27.8 \mathrm{GJ}-\mathrm{eq} / \mathrm{tonne})$ of electricity to produce one tonne of refined copper from ore grade of $1.0 \% \mathrm{Cu}$. Apparently, with the ore grade of $0.55 \% \mathrm{Cu}$, the electricity consumption requirement might be even higher. If we assume that the electricity is generated with the energy efficiency of $35 \%$, the corresponding energy consumption will be as follows:

- Flash smelter, $62 \mathrm{GJ} / \mathrm{t}-\mathrm{Cu}$

- Reverberatory smelter, $59 \mathrm{GJ} / \mathrm{t}-\mathrm{Cu}$

- $\mathrm{SX} / \mathrm{EW}$ process, $96 \mathrm{GJ} / \mathrm{t}-\mathrm{Cu}$

Apparently, the converted data are very close to other researchers results as shown above. The typical energy consumptions of some modern smelters are summarized in table 17 . 
Table 17 Energy consumption for different types of smelting technologies, GJ/t-metal refined

\begin{tabular}{|c|c|c|c|c|c|c|c|c|}
\hline Smelters & Technologies & 1997 & 1998 & 1999 & 2000 & 2001 & 2002 & 2003 \\
\hline Olympic & Flash smelting, & 25.7 & 30.7 & 25.1 & 19.4 & 19.5 & 20.6 & 21.8 \\
\hline Dam & $\mathrm{Cu}$ & & & & & & & \\
\hline Kidd & Mitsubishi & 26.4 & 23.8 & 24.2 & 24.2 & 24.9 & N/A & N/A \\
\hline Creek & $\begin{array}{l}\text { continuous, } \mathrm{Cu} \text {, } \\
\mathrm{Zn}\end{array}$ & & & & & & & \\
\hline $\begin{array}{l}\text { Horne \& } \\
\text { CCR }\end{array}$ & $\begin{array}{l}\text { Bath smelting, } \\
\mathrm{Cu}\end{array}$ & 23.0 & 21.5 & 25.4 & 26.0 & 23.3 & 23.8 & N/A \\
\hline KUCC & $\begin{array}{l}\text { Flash smelting, } \\
\mathrm{Cu}, \mathrm{Mo}\end{array}$ & & & & & & & 75.4 \\
\hline $\begin{array}{l}\text { Rönnskär } \\
\text { smelter }^{*}\end{array}$ & $\begin{array}{l}\text { Flash smelting, } \\
\mathrm{Cu}, \mathrm{Pb}, \mathrm{Zn}\end{array}$ & & & & 20.8 & 14.2 & 14.3 & \\
\hline
\end{tabular}

As shown in the above table, the typical energy consumption in primary copper production is fall in the range of 20 25 GJ/tonne, among which, 13 16 GJ/tonne of energy is used in firing smelting unit and $6 \sim 8 \mathrm{GJ} /$ tonne of energy is consumed in the electrolytic refining process.

\section{Primary Production of Molybdenum}

As discussed in 4.5 above, about $50 \%$ of the global supply of molybdenum is produced from copper mines. The rest is produced at dedicated mines.

\subsection{Ore Mining and Beneficiation}

Molybdenum is only known to occur in a natural state chemically combined with other elements. The only one of commercial significance of molybdenum-bearing minerals is molybdenite $\left(\mathrm{MoS}_{2}\right)$-a natural molybdenum sulfide. In ores, molybdenite is generally present in quantities from $0.01-0.50 \%$ as the principal metal sulfide in low-grade porphyry molybdenum 
deposits and as an associated metal sulfide in low-grade porphyry copper deposits. Reserves are mainly located in the western mountain regions of North and South America. The United States is the largest producer of Mo, and has the largest reserve base of 5.4 million tonnes, nearly half of the world's total.

Molybdenum ore was extracted as a primary product at three mines, the Henderson Mine in Colorado (operated by Phelps Dodge Corp.), with a total molybdenum concentrate production of 22,247,000 lbs in 2003), the Questa Mine in New Mexico(operated by Molycorp, Inc.), and the Thompson Creek Mine in Idaho (operated by Thompson Creek Metals Co). [US Geological Survey, in 2003 [78]

\section{Milling}

Mined ore is pulverized through a series of crushers and rotating ball and/or rod mills to fine particles that may be only microns $(1 / 1000$ th $\mathrm{mm})$ in diameter. This liberates the molybdenite from its host rock. A water slurry of the ore is then conditioned with reagents - including some fuel or diesel oil - which coats the molybdenite particles, rendering them water-repellant.

Separation by flotation takes place in aerated tanks. Molybdenite particles attach to rising air bubbles and concentrate in the surface froth, which is swept into overflow troughs. Subsequent regrinding and reflotation stages increase the molybdenite content of the new concentrate stream, by steadily removing unwanted material. The final concentrate contains between 70-90\% molybdenite. If required, an acidic leach may be employed to dissolve impurities such as copper and lead.

Depending on the individual mine source, the composition of unroasted molybdenum concentrates falls into the following range: Mo $48-58.8 \%$; $0.01-2.2 \%$ 


\section{Roasting}

During the roasting, the following reactions take place:

$2 \mathrm{MoS}_{2}+7 \mathrm{O}_{2}=2 \mathrm{MoO}_{3}+4 \mathrm{SO}_{2}$

$\mathrm{MoS}_{2}+6 \mathrm{MoO}_{3}=7 \mathrm{MoO}_{2}+2 \mathrm{SO}_{2}$

$2 \mathrm{MoO}_{2}+\mathrm{O}_{2}=2 \mathrm{MoO}_{3}$

The roasting process converts molybdenite concentrate into technical molybdic oxide by the chemical reactions above.

These take place at $600-700{ }^{\circ} \mathrm{C}$ in large multi-hearth furnaces or "roasters". Sulfide concentrate is stirred with a bar from the center to the periphery of one hearth where it drops to the hearth below and is rabbled back to the center. It reacts continuously with a steady supply of forced air during the 10 hours it takes to complete the circuit across a dozen or more hearths. The resulting technical grade molybdic oxide typically contains a minimum of $57 \%$ molybdenum, and less than $0.1 \%$ sulfur. Desulphurisation systems remove sulfur dioxide from the effluent roaster gases.

Some of the by-product molybdenite concentrates from copper mines contain small quantities $(<0.10 \%)$ of rhenium, a metallic element used in catalysts for the production of unleaded gasoline and in advanced superalloys for turbine blades of the latest jet engines. Molybdenum roasters equipped to recover rhenium are one of the principal commercial sources for this rare metal. 
Roasted molybdenite concentrates, generally known as "tech-oxide", is the principal product for adding molybdenum to alloy and stainless steels. In order to accommodate individual steelmaking requirements, tech-oxide is available in a variety of forms and packaging.

Ferromolybdenum (FeMo) is produced by the thermite reduction of tech-oxide in the presence of iron. With a typical analysis of $60-70 \%$ Mo (remainder iron), it is used as a molybdenum addition in the ladle or in melting processes, such as induction melting, which cannot reduce the oxide. Higher molybdenum content variations are also available. Western world FeMo production generates approximately 45 million lbs of Mo per year..

Some molybdenum containing alloys, such as super-alloys, cannot tolerate iron and must be melted with molybdenum metal. Some technical oxide is further processed into pure molybdenum metal. The oxide powder is then reduced in hydrogen and the metal powder is compressed into billets prior to required forming operations.

The Langeloth Metallurgical Company, an affiliate of the Thompson Creek Metals in the US, processes molybdenum concentrate as primary ore. Molybdenum concentrated ore, containing over $90 \%$ molybdenite, arrives daily by truck from Thompson Creek Mine near Clayton, Idaho. Currently, the Langeloth Metallurgical Company operates three Nichols-Herreshoff multiple hearth roasters, which have combined daily capacity of $90,0001 \mathrm{~b}(\sim 41,000 \mathrm{~kg})$ of molybdenum. It is in these roasters that the concentrate $\left(\mathrm{MoS}_{2}\right)$ is converted to technical grade molybdic oxide $\mathrm{MoO}_{3}$ ). The finished product contains less than $0.1 \%$ sulfur. Technical-grade molybdenum trioxide (tech-oxide) is the principal molybdenum product. $\mathrm{SO}_{2}$ released through the production of molybdic oxide is processed in a designated acid plant and recovered as sulfuric acid. The $\%$ efficiency of $\mathrm{SO}_{2}$ capture is not reported. 
Emission factors of molybdenum as primary product. In the United States, molybdenum is also produced as primary metal. Since no direct information available for the $\mathrm{SO}_{2}$ emission factors in the primary molybdenum production process, we can calculate emission factors from roasting reactions of molybdenite concentrate at different sulfur fixation levels. The estimated emission of $\mathrm{SO}_{2}$ is listed in table 18 .

Table 18 Estimated $\mathrm{SO}_{2}$ emission factor in molybdenum production from ore

\begin{tabular}{|c|c|c|c|c|c|c|c|c|c|c|}
\hline $\begin{array}{ll}\text { Sulfur fixation } 80 \\
\text { percentage, } \%\end{array}$ & 82 & 84 & 86 & 88 & 90 & 92 & 94 & 96 & 98 & 99 \\
\hline $\begin{array}{lll}\mathrm{SO}_{2} \text { emission, } & \text { kg- } 267 \\
\mathrm{SO}_{2} / \text { tonne-Mo } & & \\
\text { produced } & & \end{array}$ & 240 & 214 & 187 & 160 & 134 & 107 & 80 & 53 & 27 & 13 \\
\hline
\end{tabular}

\section{Production of Alumina and Gallium}

\subsection{Ore Composition Mining and Beneficiation}

Aluminum is the third most abundant element in the earth's crust after oxygen and silicon. Because of its chemical reactivity, aluminum is never found in nature as an element; it is present in its oxidized form in about 250 different minerals. The main ore used in the production of aluminum is known as bauxite, after the French district of Les Baux where it was first discovered in 1821. Bauxites contain hydrated forms of aluminum oxide and occur in three main forms depending on a) the number of molecules of water of hydration and b) the crystalline structure. The three structural forms of bauxite are gibbsite $\left(\mathrm{Al}_{2} \mathrm{O}_{3} \cdot 3 \mathrm{H}_{2} \mathrm{O}\right)$, böhmite $\left(\mathrm{Al}_{2} \mathrm{O}_{3} \cdot \mathrm{H}_{2} \mathrm{O}\right)$, and diaspore $\left(\mathrm{Al}_{2} \mathrm{O}_{3} \cdot \mathrm{H}_{2} \mathrm{O}\right)$. Of the bauxite ores currently being mined the dominant form is gibbsite, followed by a mixed ore of gibbsite and böhmite. 
Eighty percent of world bauxite production is from surface mines, with the rest, mainly from Southern Europe and Hungary, from underground mines. Unlike the base metal ores, bauxite does not require extensive beneficiation because most of the bauxite mined is sufficiently concentrated grade or can be improved by a relatively simple and inexpensive process of removing clay.

\subsection{Production of Aluminum}

Aluminum can be produced via two different routes: primary aluminum production from ore and recycling aluminum from process scrap and used aluminum products. The aluminum oxide that is extracted from bauxite is known as alumina - a white fine dry powder. More than 90 per cent of the world's alumina production is used to make aluminum. The production of primary aluminum from ore consists of three steps: bauxite mining, alumina production, and electrolysis.

Alumina production. The aluminum industry relies on the Bayer process to produce alumina from bauxite with variations to account for differences in the types and quality of bauxite used. The Bayer process remains the most economic means of obtaining alumina, which is used for the production of aluminum metal. The process of producing pure alumina from bauxite has changed very little since the first plant was opened in 1893. Generally, the Bayer process can be considered in four stages:

\section{Digestion:}

In this stage, the bauxite is washed, ground, and dissolved in caustic soda (sodium hydroxide) under high pressure and temperature conditions. 
The hydrated alumina is selectively removed from the other (insoluble) oxides by transferring it into a solution of sodium hydroxide (caustic soda) according to the following reaction:

$\mathrm{Al}_{2} \mathrm{O}_{3} \cdot \mathrm{xH} 2 \mathrm{O}+2 \mathrm{NaOH}=2 \mathrm{NaAlO}_{2}+(\mathrm{x}+1) \mathrm{H}_{2} \mathrm{O}$

The digestion is completed within a digester, typically operated at between 200 and $240{ }^{\circ} \mathrm{C}$ and can involve pressures of around $30 \mathrm{~atm}$. The concentration of caustic soda can be as high as $10 \%$.

\section{Clarification:}

The removal of residues from the liquor stream after the digestion stage is complete.

After the digestion, the liquor (containing the dissolved $\mathrm{Al}_{2} \mathrm{O}_{3}$ ) must be separated from the insoluble bauxite residues (containing iron, silicon, and titanium), purified as much as possible and filtered before it is delivered to a decomposer. These residues sink gradually to the bottom of the tank and are removed. They are known colloquially as "red mud". Bauxite residues (also known as red mud) are by-products of the Bayer Process. The amount of residues generated, per tonne of alumina produced, varies depending on the type of bauxite used, from 0.3 tonnes for high-grade bauxite to 2.5 tonnes for very low grade. The red mud is thickened and washed so that the caustic soda can be removed and recycled.

3. Precipitation: The removal of crystals of alumina hydrate from the caustic solution of the liquor stream.

After clarification, the clear sodium aluminate solution is pumped into a huge tank called a precipitator. In this stage, crystalline alumina trihydrate is extracted from the digestion liquor by the following hydrolysis reaction:

$2 \mathrm{NaAlO}_{2}+4 \mathrm{H}_{2} \mathrm{O}=\mathrm{Al}_{2} \mathrm{O}_{3} \cdot 3 \mathrm{H}_{2} \mathrm{O}+2 \mathrm{NaOH}$ 
This is basically the reverse of the digestion process. Fine particles of alumina are added to seed the precipitation of pure alumina particles as the liquor cools. The particles sink to the bottom of the tank and are removed. The liquor is recycled back to digestion.

4. Calcination: The removal of water crystallization from the alumina hydrate after precipitation. In this stage, the alumina trihydrate crystals are passed through a rotary calcination kiln or a fluidized calciner at $1100^{\circ} \mathrm{C}$ to drive off the chemically combined water. The final product is a fine white anhydrous aluminum oxide powder called alumina. This is the basic material from which aluminum is made.

\section{Electrolysis.}

Electrolysis is the transformation of alumina into aluminum. In the primary aluminum production process, alumina is used as raw material. The primary aluminum industry is dependent on a regular supply of alumina for four functions:

- Basic raw material for aluminum production

- Thermal insulator for the top of electrolytic cells

- Coating for pre-baked anodes

- Absorbent filter for cell emissions

The basis for all modern primary aluminum smelting plants is the Hall-Héroult Process, invented in 1886. Electrolysis of aluminum is completed in a pot. The pot contains a molten electrolyte, called "bath". Alumina is dissolved in the electrolytic bath of molten cryolite within the "pot". The electrolyte is a mixture of cryolite $\left(\mathrm{Na}_{3} \mathrm{AlF}_{6}\right)$, a molten salt, and certain additives to give it appropriate density, conductivity and viscosity. The principal additive is aluminum fluoride $\left(\mathrm{A}_{1} \mathrm{~F}_{3}\right)$, which must be replaced from time to time due to losses through evaporation and a chemical reaction converting it into more cryolite. An electric current is passed through the 
electrolyte at low voltage, but very high current, typically 150,000 amperes. The electric current flows between a carbon anode (positive), made of petroleum coke and pitch, and a cathode (negative), formed by the thick carbon or graphite lining of the pot. Molten aluminum is deposited at the bottom of the pot and is siphoned off periodically, taken to a holding furnace, often but not always blended to an alloy specification, cleaned and then generally cast. On average, around the world, it takes some $15.7 \mathrm{kWh}$ of electricity to produce one kilogram of aluminum from alumina.

There are two main types of aluminum smelting technology_-"Söderberg" and "Pre-bake". The principal difference between the two is the type of anode used.

- Söderberg technology uses a continuous anode which is delivered to the cell (pot) in the form of a paste, and which bakes in the cell itself.

- Pre-bake technology uses multiple anodes in each cell, which are pre-baked in a separate facility and attached to "rods" that suspend the anodes in the cell. New anodes are exchanged for spent anodes - "anode butts" - being recycled into new anodes.

Both types are made from the same basic materials and react in the same way. A mixture of petroleum coke and pitch is strongly heated causing the pitch to bind the coke particles together. "Pre-baked" anodes are made before they are added to the pot, but "Söderberg" anodes are actually formed and baked in the pot. The Söderberg anode uses the waste heat of reaction in each pot to pyrolyze the coke and pitch. As the lower part of the anode is consumed in the reaction, more raw materials are added at the top. During the baking process many volatile products are driven off as the pitch hydrocarbons are dehydrogenated. Solid carbon is left as the anode. 
Although the Söderberg anode may be more energy efficient it is easier to treat the volatile wastes if they are not mixed with the other emissions from the pot. Dehydrogenation is often less complete in the Söderberg anode causing more hydrogen fluoride to be formed during the anode reaction. So, for environmental reasons, modern smelters use prebaked anodes.

In general terms, two to three tonnes of bauxite are required to produce one tonne of alumina and two tonnes of alumina are required to produce one tonne of aluminium metal, depending on the grade of bauxite used. About 0.5 tons of carbon is used to produce every ton of aluminum.

Most smelters produce aluminum of $99.7 \%$ purity, which is acceptable for most applications.

World production of primary aluminum increased to 24.51 million metric ton (Mt ) in 2001 from 24.46 Mt in 2000. It is estimated that world primary aluminum production in 2002 increased by about $5.8 \%$ to $25.9 \mathrm{Mt}$. The world primary aluminum production level was $25.9 \mathrm{Mt}$ and $27.3 \mathrm{Mt}$ in 2002 and 2003 respectively.

Aluminum is also recovered from new (manufacturing) scraps and from old scraps (discarded aluminum products). As an example, the United States primary aluminum and secondary aluminum productions in the last few years are listed in table 19.

Table 19. The US aluminum production levels (units in thousand metric tons) [79]

\begin{tabular}{llllll}
\hline Year & 1999 & 2000 & 2001 & 2002 & 2003 \\
\hline Primary & 3779 & 3668 & 2637 & 2707 & 2700 \\
New scrap & 2120 & 2080 & 1760 & 1750 & N/A \\
Old scrap & 1570 & 1370 & 1210 & 1170 & 1100 \\
\hline
\end{tabular}

\subsection{Gallium Production}

$95 \%$ of the world's production is obtained from the sodium aluminate liquor that is produced as part of the Bayer process for extracting alumina from bauxite. The remainder is produced only 
part of the gallium present in bauxite and zinc ores is recoverable, and the factors controlling the recovery are proprietary. Data on world production of primary gallium are unavailable because data on the output of the few producers are considered to be proprietary. However, in 2003, world primary production was estimated to be about 64 tonnes, about the same as that in 2002 . China, Germany, Japan, and Russia were the largest producers; countries with smaller output were Hungary, Kazakhstan, Slovakia, and Ukraine. Refined gallium production was estimated to be about 83 tonnes. This figure includes some scrap refining. France was the largest producer of refined gallium, using as feed material crude gallium produced in Germany. Japan and the United States were the other large gallium-refining countries. Gallium was recycled from new scrap in Germany, Japan, the United Kingdom, and the United States.

World-wide estimated annual primary gallium production capacity is shown in Figure 14. In the United States, no domestic primary gallium recovery was reported in 2003. One company in Oklahoma recovered and refined gallium from scrap and impure gallium metal.

The main source of gallium is bauxite where it is present in low concentrations (e.g., $<0.01$ wt\%) [80]. It is extracted as a byproduct of alumina from the bauxite in the Bayer process. This process follows four stages: First, in digestion, finely ground bauxite is pumped into a large pressure vessel or digester where it is mixed with caustic soda and steam at $250^{\circ} \mathrm{C}$. The alumina and caustic soda create a sodium aluminate solution. Second, clarification is where the insoluble impurities are separated from the sodium aluminate solution. Third, in the precipitation stage, alumina crystallized or precipitated from the solution to create alumina trihydrate. The remaining alumina liquor is recycled and placed back into the digester. Fourth, during 
calcination, the alumina trihydrate is washed and then dried at $1050^{\circ} \mathrm{C}$ to remove the water crystals, so only alumina is left [81].

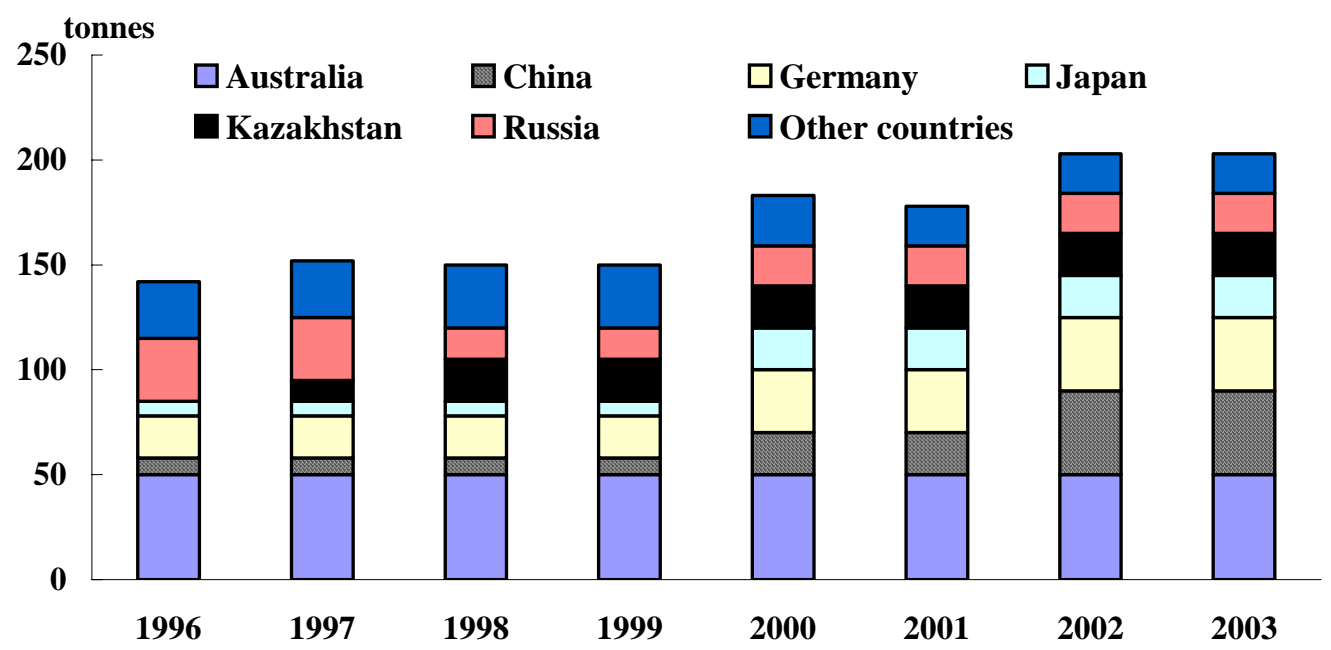

Figure 14 Estimated World Primary Gallium Production Capacity [98], 1996-2003(Source: Based on the United States Geological Survey estimates)

Gallium is contained in the caustic solution, which is recycled in the Bayer process. Usually after the concentration of gallium has reached 100 to $125 \mathrm{ppm}$, a fraction of the caustic solution will be removed and gallium will be extracted. Common processes to recover gallium include: (1) fractional precipitation, (2) electrolytic process and (3) solvent extraction/ion exchange process [82].

The Beja process is actually a fractional precipitation method. In this process, the stream of alumina liquor is saturated by carbon dioxide to precipitate about $90 \%$ of the remaining alumina that was not recovered by the Bayer process. Then the solution is again injected by carbon dioxide to precipitate out the gallium. The precipitate only contains about 0.3 to $1 \%$ gallium, but $90 \%$ of the gallium is removed from the solution. Once the gallium is precipitated, it is dissolved in a caustic solution to increase the gallium-to-aluminum ratio. The solution is then electrolyzed to recover crude gallium $(\approx 99.9 \%$ pure $)$ as a liquid. The remaining solution is 
returned to the Bayer process to start the cycle over again [83], [84] (see Figure 15). "This process is quite labor intensive and can therefore be used only when energy and labor costs are low. The People's Republic of China produces gallium at a rate of $5 \mathrm{t} / \mathrm{a}$ by this process [85]."

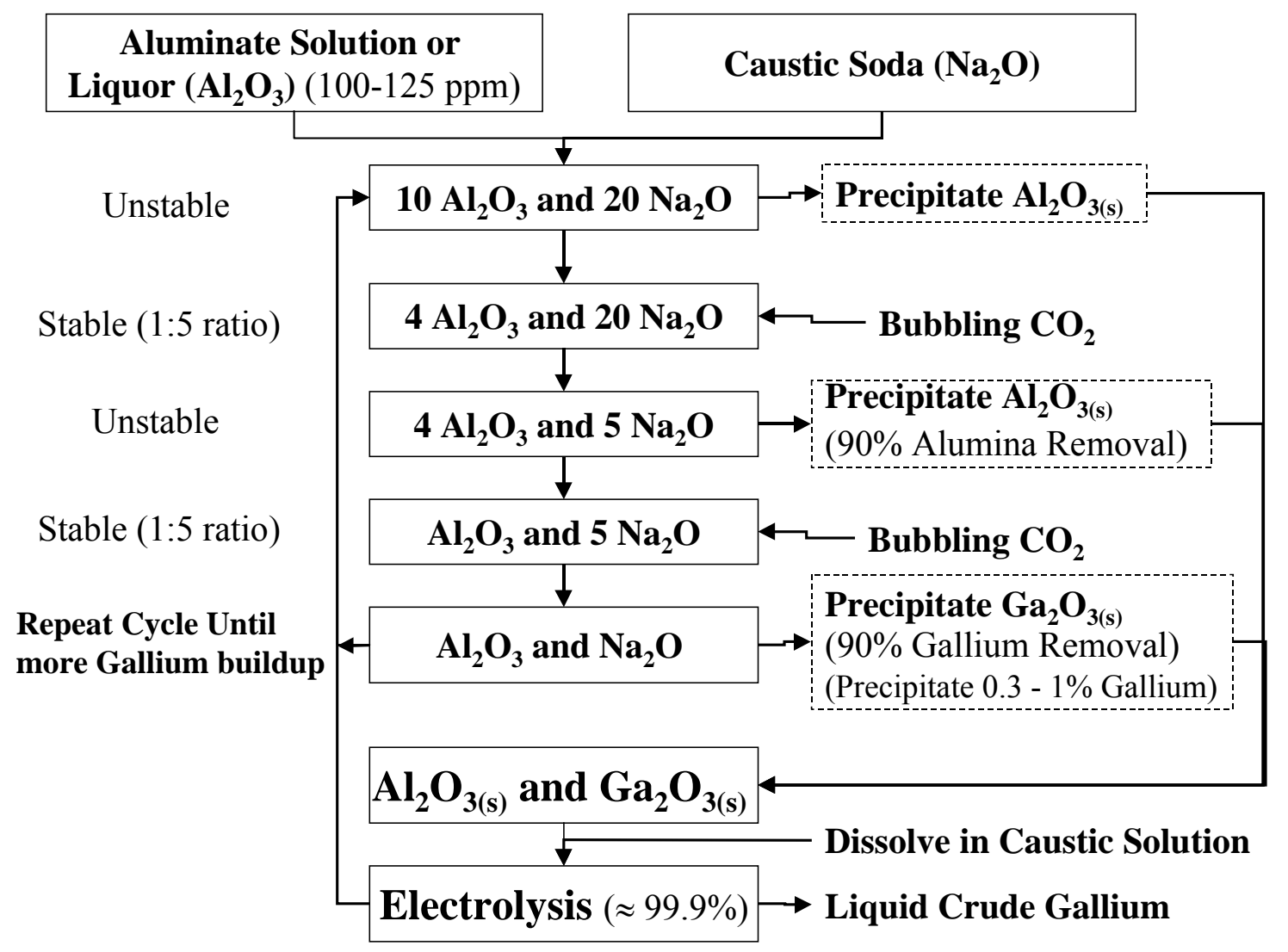

Figure 15 Gallium Purification - Beja Process [83], [84]

The de la Breteque process is an electrolytic route. In the de la Breteque process, the solution is first evaporated to increase the concentration of gallium. Then a highly agitated mercury cathode electrolyzes the solution. Gallium forms an amalgam with the mercury, and once the concentration of gallium reaches $1 \%$, the amalgam is removed from the cathode. The gallium deposit from the mercury is extracted by means of a caustic solution, in which a temperature increase is favored [86]. From these steps, crude gallium $(\approx 99.9 \%$ pure $)$ is extracted through 
electrolysis, although "the deposit of gallium is rather proportional to the duration of the electrolysis [86]" (see Table 1). This process was used in Hungary, Slovakia, and Germany. In total, about $15-20 \mathrm{t} / \mathrm{a}$ of gallium is produced [85].

The Beja and de la Breteque processes are obsolete and "being replaced by solvent extraction in which the gallium is removed from the liquor by reaction with organic chelating agents [80]" such as in the Rhône-Poulenc and Sumitomo processes. In Japan and Germany, the RhônePoulenc and Sumitomo processes are used. Gallium is recovered from the Bayer sodium aluminate liquors.

The Rhône-Poulenc and Sumitomo processes, which are similar, are based on solvent extraction and ion exchange procedure.

In the Rhône-Poulenc process, the aluminate liquor comes "into contact with a solution of Kelex 100 in kerosene [85]," in which gallium is extracted along with aluminum and sodium. In the primary extraction, gallium is extracted with dilute hydrochloric or sulfuric acid. One problem is that although some of the acid is recycled, large amounts of acid are contaminated by other metals and require disposal. "Further concentration of the gallium is achieved by anionor cation-exchange treatment of the acid extract from the first stage [85]," and then it could go through electrolysis. In the Sumitomo process, the first stage extraction uses the ion-exchange resin Duolite CS-346 to form chelate bonds to gallium instead of 7-alkyl-8-hydroxyquinoline, or Kelex 100 , a commercially available chelating extractant [87]. The problem here is that the vanadium extracted blocks the ion exchange sites. The rest of the process follows the RhônePoulenc process.

In Western Australia, the French-owned company Rhodia Pinjarra Pty Ltd established a gallium extraction plant at Pinjarra near the Alcoa alumina refinery. The plant commenced 
production of gallium chloride in 1989 and had a capacity of 50t/a of gallium in solution. The process relies on the extraction of dissolved gallium from the liquor stream via the Bayer method of processing bauxite to alumina. The liquor (obtained from Alcoa's Pinjarra alumina refinery) is pumped to the gallium plant via a pipeline and passed through a battery of mixer-settlers, in counter-flow to an organic solvent. The solvent flow leaving the battery is then loaded with gallium, plus low levels of impurities such as alumina, sodium and iron. These impurities are removed from the solvent by an acid wash. The acidic solution is then passed through a bed of ion exchange resin. The gallium is fixed in the resin and the impurities remain in solution. The gallium is extracted from the resin as a gallium chloride solution, which is concentrated and drummed. The gallium-depleted liquor is then pumped back to the alumina refinery for the removal of the dissolved alumina. This process is totally hydrometallurgy-based and, as such, it is not expected to produce any gaseous emissions.

The purity of crude gallium ranges between 96.0 to $99.99 \%$; however, current photovoltaic module manufacturing usually prefers $99.999 \%$ or higher purity. One established purification procedure involves the distillation of volatile metals such as mercury and zinc while under vacuum. Additional purification is accomplished by means of fractional crystallization, zone melting, or single crystal growth [82]. Electrolytic refining method is also used (see figure 16). In the electrolysis, using stainless steel electrodes at $40-60{ }^{\circ} \mathrm{C}$ in an alkaline solution, "gallium is deposited as a liquid at the bottom of the vessel, and after washing in hydrochloric or nitric acid, it can be filtered through porous ceramic or glass plates [80]." In the distillation procedure, gallium is filtrated and heated under a vacuum to remove the impurities. Then it is washed with hydrochloric acid. Electrolysis purifies gallium up to 4 nines $(4 \mathrm{~N})$, but if it is performed a few cycles, it is possible to reach $7 \mathrm{~N}$. To reach $6 \mathrm{~N}$ or $7 \mathrm{~N}$, the gradual crystallization of molten 
gallium is used [83]. When the gallium crystallizes, most of the impurities remain in liquid form. Therefore, if a sample undergoes a few cycles of crystallization, each time fewer impurities would be in the gallium. An alternative method for purification is to convert gallium into a halide compound, such as gallium trichloride [88]. The majority of the impurities are zinc, lead, aluminum, copper and vanadium (see table 20). Then after electrolysis of the gallium trichloride, high-purity gallium would achieve to $6 \mathrm{~N}$ or $7 \mathrm{~N}$ (see Figure 17).

Table 20 Amount of Impurities in $1 \mathrm{~kg}$ of Gallium Metal after Purification [88]

\begin{tabular}{cccccc}
\hline \multicolumn{5}{c}{ From $1 \mathrm{~kg}$ of gallium metal $(\sim 96 \%$ pure $)$} \\
\hline & Initial Concentration & $5 \%$ becomes & Condensation & Condensation & Electrolysis \\
$\mathrm{Zn}$ & $(\mathrm{g})$ & $\mathrm{GaCl}_{2}(\mathrm{~g})$ & $(\mathrm{g})$ & $(\mathrm{ppm})$ & $(\mathrm{ppm})$ \\
$\mathrm{Pb}$ & 22.7 & 0.007 & $<0.001$ & $<1$ & $<1$ \\
$\mathrm{Al}$ & 15.7 & 0.375 & $<0.001$ & $<1$ & $<1$ \\
$\mathrm{Cu}$ & 0.06 & 0.060 & $<0.012$ & $<12$ & $<5$ \\
$\mathrm{~V}$ & 0.02 & 0.005 & $<0.001$ & $<1$ & $<1$ \\
$\mathrm{Purity}$ & 0.007 & $<0.005$ & $<0.005$ & $<5$ & $<5$ \\
\hline
\end{tabular}




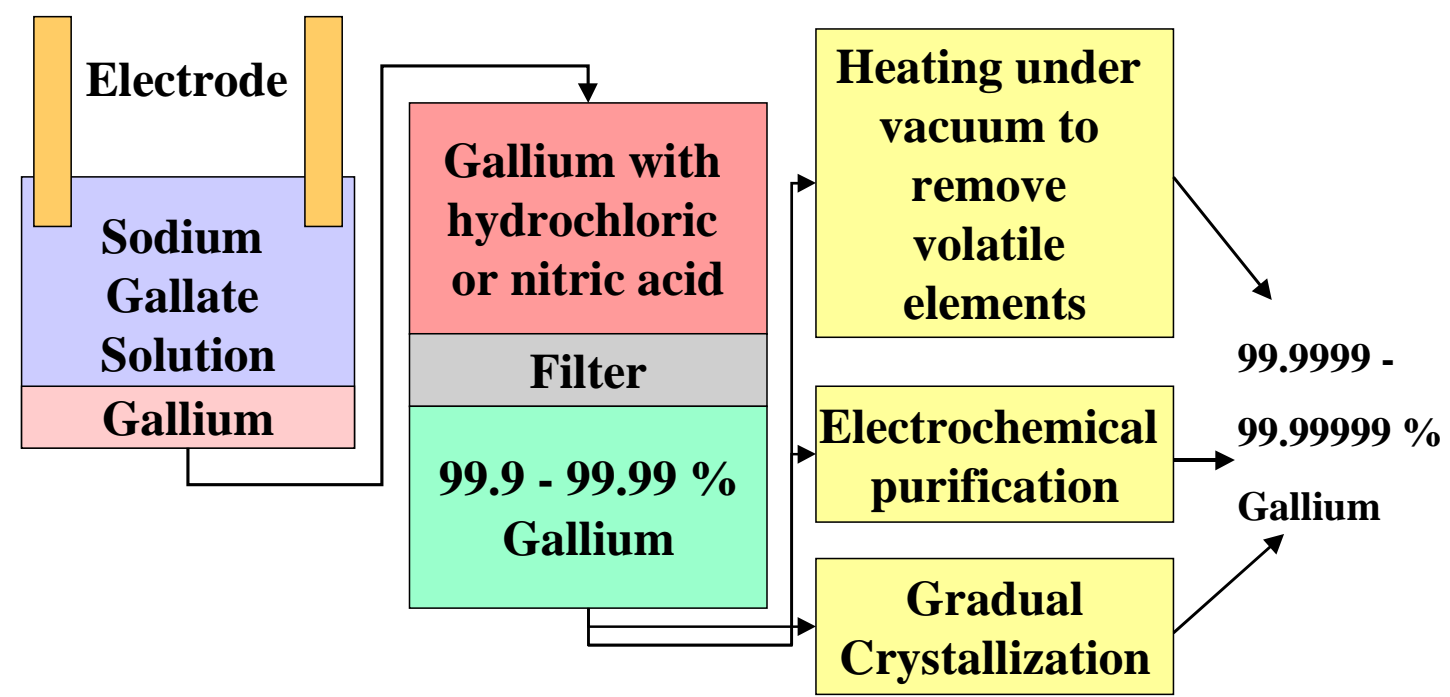

Figure 16 Gallium Purification - Electrolytic Refining [83].

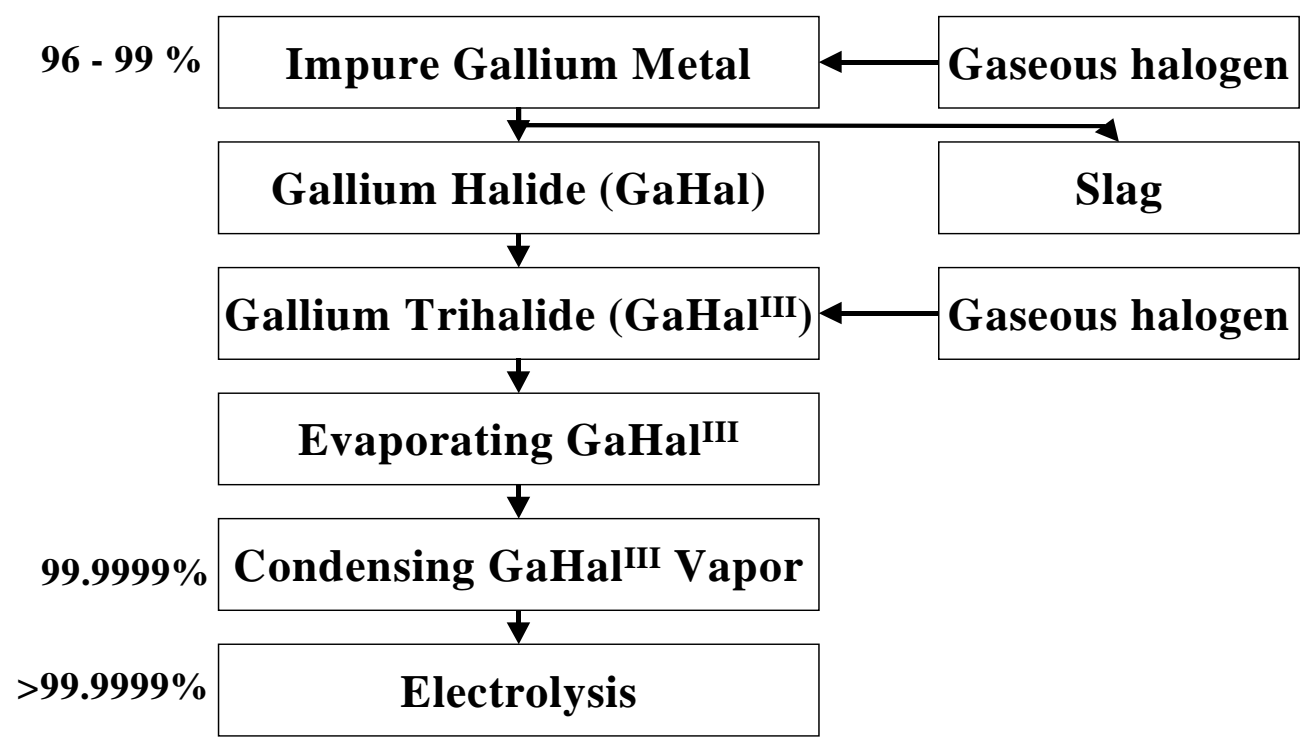

Figure 17 Gallium Purification - Halide [88]. 


\subsection{Emission factors in the co-production of aluminum and gallium:}

Fluoride emission. Commercial aluminum production relies on separating the aluminum metal from alumina. However, the chemical bond between the aluminum and oxygen molecules is extraordinarily strong and requires significant energy to break it.

Dissolving alumina in a molten mixture of sodium aluminum fluoride, also known as cryolite, at temperatures around $920{ }^{\circ} \mathrm{C} 980{ }^{\circ} \mathrm{C}$ minimizes the energy required to produce pure aluminum. Emissions released from molten cryolite include hydrogen fluoride gas, fluoride salts, and small amounts of perfluorohydrocarbons. There are two main types of fluoride emissions:

- A mixture of the inorganic fluorides $\mathrm{NaF}, \mathrm{AlF}_{3}$ and $\mathrm{Na}_{3} \mathrm{AlF}_{6}$ (as particulates) and $\mathrm{HF}$ (as a gas);

- The organic perfluorocarbons ( $\mathrm{PFCs})\left(\mathrm{CF}_{4}\right.$ and $\left.\mathrm{C}_{2} \mathrm{~F}_{6}\right)$ as gases.

The fluoride gases and solids released during the smelting process are controlled by various equipment, methods, and treatment. The most efficient of the commercially used treatment systems is the adsorptive alumina-based filter system, which uses fresh alumina to capture more than $99.4 \%$ of the emissions. Fluoride gases are passed through a bed of alumina where fluoride is adsorbed. The particulate matter is then collected in a fabric filter bag-house. The reacted or fluoride-containing alumina is recycled into the aluminum production process. The alumina from the filter system is eventually used in the smelting process, carrying with it the adsorbed fluorides so that material can be recycled into the smelting process. Small amounts of fluoride could escape from the smelting process, typically during operations such as anode changing when sections of pot hooding are removed. According to the International Aluminum Institute, in 
1990 the average worldwide of emissions of fluride to atmosphere were $1.1 \mathrm{~kg} ;(0.5 \mathrm{~kg}$ for new modern plants) of fluoride per tonne of aluminum. This is a great reduction from $3.9 \mathrm{~kg}$ per tonne reported in 1974 [89].

The International Aluminum Institute categorizes fluoride reductions into 3 generations of plants [89].

Table 21. Development in Fluoride Emissions from Aluminum Smelters, kg-Fluoride/t-Al produced

\begin{tabular}{lll}
\hline 1st Generation Plants & $1940-1955$ & $12-15 \mathrm{~kg}$ per tonne \\
\hline 2nd Generation Plants & $1955-1975$ & $2-6 \mathrm{~kg}$ per tonne \\
3rd Generation Plants & 1975 -today & $0.3-1 \mathrm{~kg}$ per tonne \\
\hline
\end{tabular}

The fluoride emissions at Alcoa are listed in Table 22 and Table 23.

Table 22. Average fluoride emissions levels at Alcoa's world-wide primary aluminum plants

\begin{tabular}{lllll}
\hline Year & 2000 & 2001 & 2002 & 2003 \\
\hline Fluoride emissions, kg/tonne-Al & 0.95 & 0.92 & 0.89 & 0.84 \\
\hline
\end{tabular}

Table 23 Fluoride emission levels at Alcoa's two aluminum smelters in Australia (kg/tonne$\mathrm{Al})[90]$

\begin{tabular}{lcccccccccc}
\hline $\begin{array}{l}\text { Year/ } \\
\text { Mine }\end{array}$ & 1994 & 1995 & 1996 & 1997 & 1998 & 1999 & 2000 & 2001 & 2002 & 2003 \\
\hline Point Henry & 0.67 & 0.94 & 1.13 & 0.81 & 0.97 & 1.25 & 1.47 & 1.58 & 2.10 & 0.98 \\
Portland & 0.26 & 0.42 & 0.33 & 0.32 & 0.31 & 0.30 & 0.33 & 0.40 & 0.38 & 0.34 \\
\hline
\end{tabular}

As described before, there are two types of carbon anodes used in the aluminum electrolysis pot, which are "Pre-baked" anodes and "Söderberg" anodes. The emission levels of fluorides are therefore different depending on the anode type. Generally, the use of "Pre-baked" anode generates less emission of fluorides. This can be seen from figure 18 . 


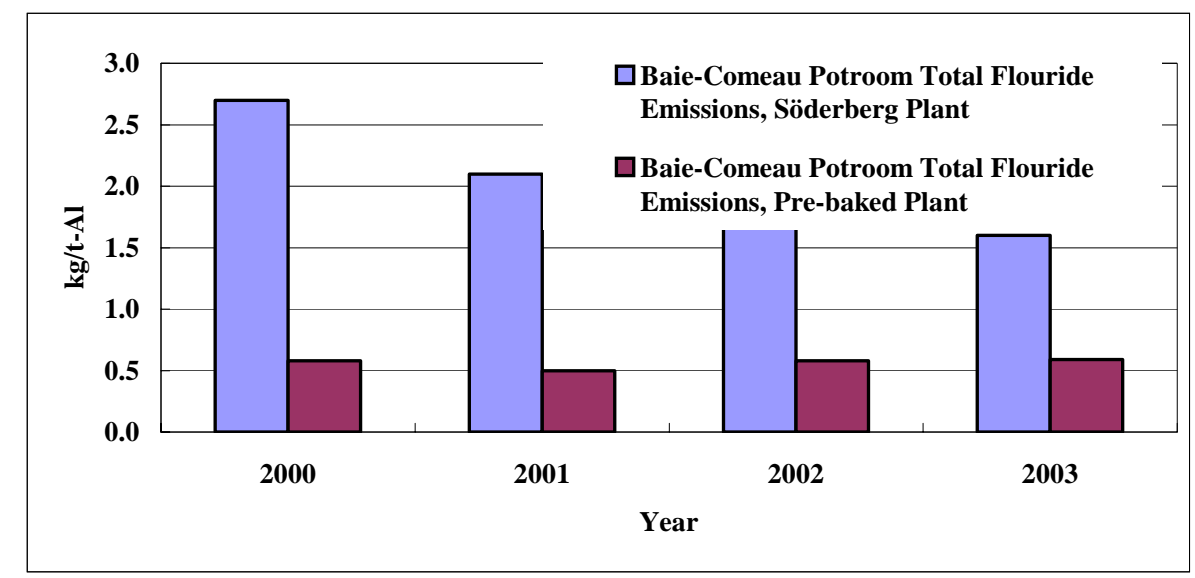

Figure 18 The fluorides emission level at Alcoa's Baie-Comeau operation in Canada [91]

Table 24 The fluorides emission level at Alcoa's Baie-Comeau operation in Canada(kg/t-Al)[91]

\begin{tabular}{lllll}
\hline Year & 2000 & 2001 & 2002 & 2003 \\
\hline Söderberg plant & 2.7 & 2.1 & 1.8 & 1.6 \\
Pre-baked plant & 0.58 & 0.50 & 0.58 & 0.59 \\
\hline
\end{tabular}

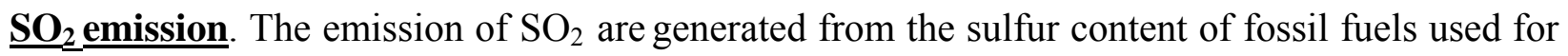
the generation of electricity required for aluminum production (e.g., steam generation in alumina plants, ovens in anode plants and anode consumption in the electrolysis pots). The emissions of $\mathrm{SO}_{2}$ in Alcoa's aluminum electrolysis operations in Canada are around $15 \sim 20 \mathrm{~kg}-\mathrm{SO}_{2} /$ Tonne-Al (Figure 19). 


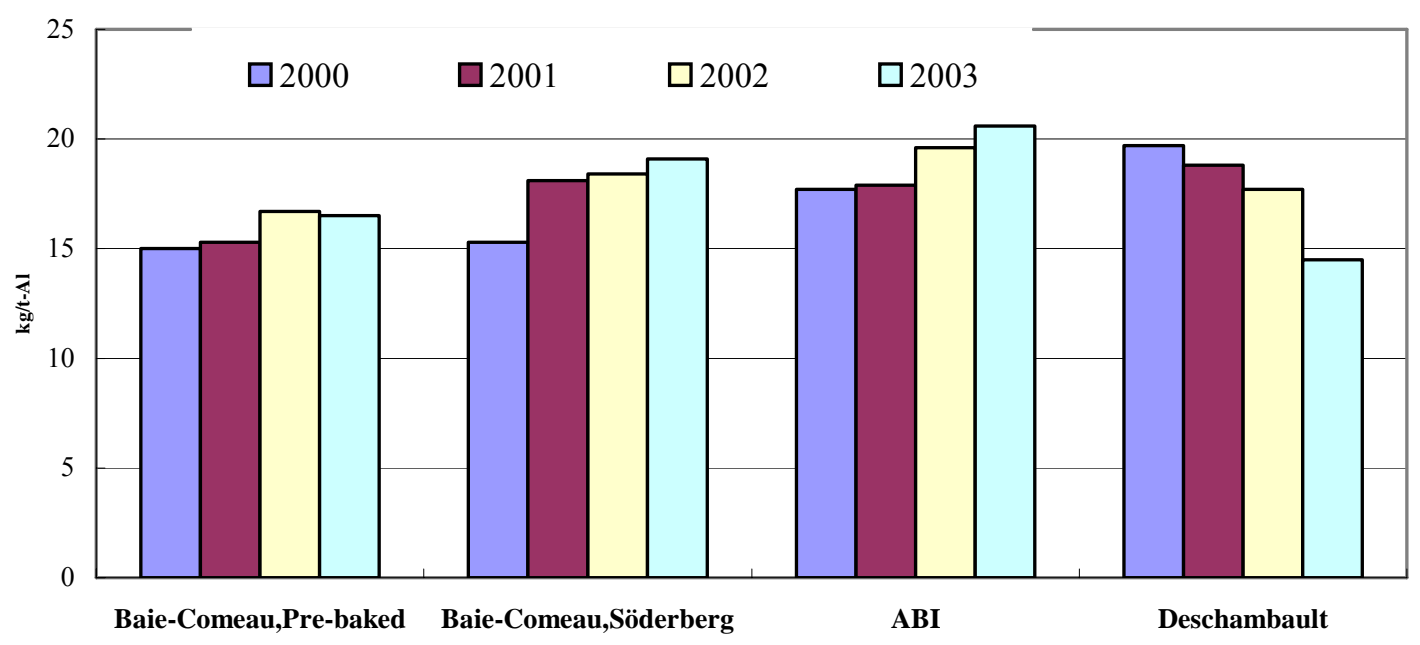

Figure 19 The $\mathrm{SO}_{2}$ emission level at Alcoa's operations in Canada [91].

Table 25 The $\mathrm{SO}_{2}$ emission level at Alcoa's operations in Canada(kg/t-Al) [91].

\begin{tabular}{lcccc}
\hline Year & 2000 & 2001 & 2002 & 2003 \\
\hline $\begin{array}{l}\text { Baie-Comeau } \\
\text { Pre-bake }\end{array}$ & 15.0 & 15.3 & 16.7 & 16.5 \\
$\begin{array}{l}\text { Baie-Comeau } \\
\text { Söderberg }\end{array}$ & 15.3 & 18.1 & 18.4 & 19.1 \\
ABI & 17.7 & 17.9 & 19.6 & 20.6 \\
Deschambault & 19.7 & 18.8 & 17.7 & 14.5 \\
\hline
\end{tabular}

Greenhouse gas emissions. On average the smelting process itself is now responsible, per tonne of aluminum, for the production of 1.7 tonnes of $\mathrm{CO}_{2}$ (from the consumption of the carbon anodes) and the equivalent of an additional 2 tonnes $\mathrm{CO}_{2}$ from Perfluorocarbon $(\mathrm{PFCs})\left(\mathrm{CF}_{4}\right.$ and $\mathrm{C}_{2} \mathrm{~F}_{6}$ ) emissions. PFCs are not generated during normal smelting operating conditions. They are only produced during brief upset conditions known as "anode effects". These conditions occur when the level of the dissolved aluminum oxide (the raw material for primary aluminum) in the cell drops too low and the electrolytic bath itself begins to undergo electrolysis. Measures to 
reduce the frequency and duration of anode effects not only reduce greenhouse gas emissions but they also benefit the producer by improving energy and process efficiency. The greenhouse gas emissions at Alcoa's Canada smelters are shown in Figure 20. (The emission data reported here do not consider the fuel usage, they are solely from the consumption of carbon anode during electrolysis, which generates $\mathrm{CO}, \mathrm{CO}_{2}$, and PFCs directly.
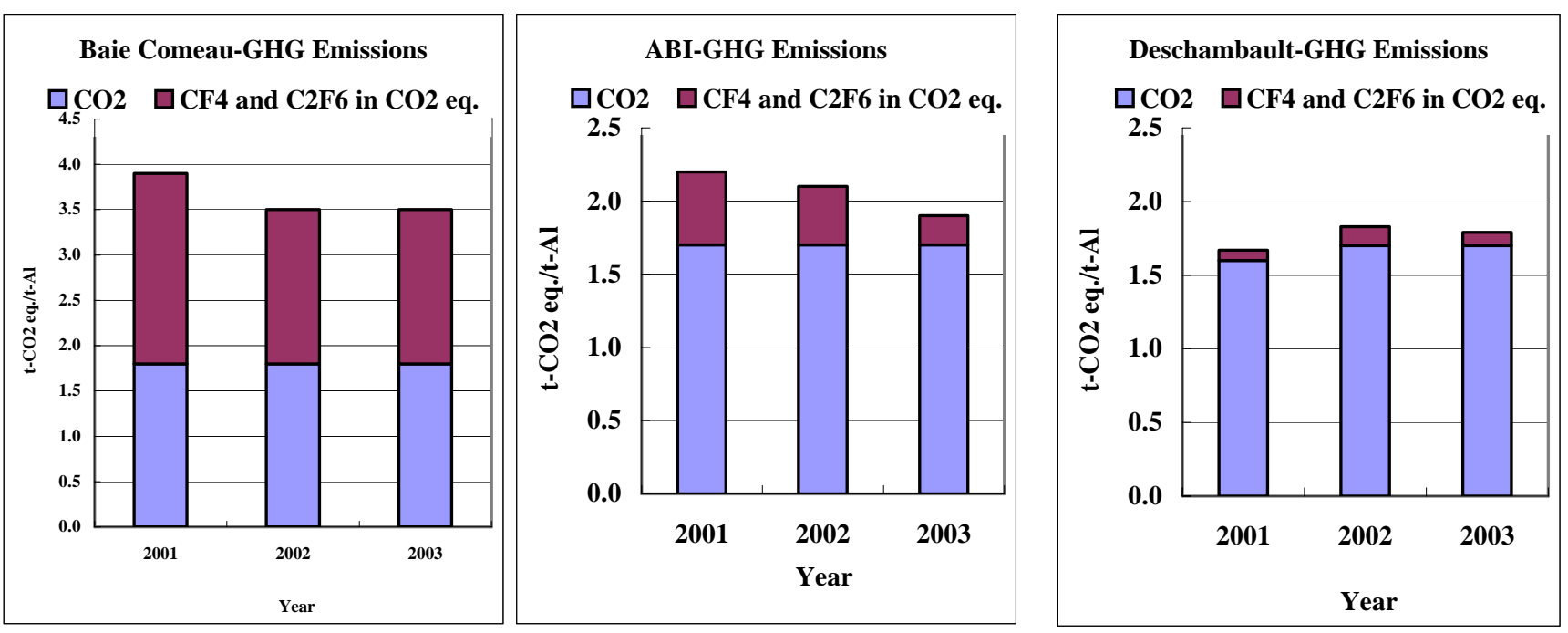

Figure 20. The greenhouse gas emission levels at Alcoa's operations in Canada [91]

Table 26 Greenhouse gas emission levels at Alcoa's operations in Canada $\left(\mathrm{t}-\mathrm{CO}_{2} \mathrm{eq} / \mathrm{t}-\mathrm{Al}\right)[91]$

\begin{tabular}{lllll}
\hline Year & & 2001 & 2002 & 2003 \\
\hline \multirow{2}{*}{ Baie-Comeau } & $\mathrm{CO}_{2}$ & 1.8 & 1.8 & 1.8 \\
& $\mathrm{CF}_{4}$ and $\mathrm{C}_{2} \mathrm{~F}_{6}$ in $\mathrm{CO}_{2}$ eq. & 2.1 & 1.7 & 1.7 \\
& $\mathrm{CO}_{2}$ & 1.7 & 1.7 & 1.7 \\
\multirow{2}{*}{$\mathrm{ABI}$} & $\mathrm{CF}_{4}$ and $\mathrm{C}_{2} \mathrm{~F}_{6}$ in $\mathrm{CO}_{2}$ eq. & 0.5 & 0.4 & 0.2 \\
& $\mathrm{CO}_{2}$ & 1.6 & 1.7 & 1.7 \\
\multirow{2}{*}{ Deschambault } & $\mathrm{CF}_{4}$ and $\mathrm{C}_{2} \mathrm{~F}_{6}$ in $\mathrm{CO}_{2}$ eq. & 0.07 & 0.13 & 0.09 \\
\hline
\end{tabular}


About one third of the aluminum used world-wide however is produced from recycled aluminum scrap - a process which only produces a total of 0.18 tonnes of $\mathrm{CO}_{2}$ per tonne of aluminum.

\subsection{Energy factors in the production of Aluminum and by-Products}

The electrolysis process to generate primary aluminum requires significant amounts of energy. For example, the energy consumption in an aluminum smelter of Alcoa's operations in Canada was in the range of 55 59 MJ/kg-Al between 2001 and 2003[91]. The Alcoa's worldwide aluminum smelting operations' energy consumption in the last ten years has declined from 14.9 $\mathrm{kWh} / \mathrm{kg}-\mathrm{Al}(53.6 \mathrm{MJ} / \mathrm{kg})$ to $14.3 \mathrm{kWh} / \mathrm{kg}-\mathrm{Al}(51.5 \mathrm{MJ} / \mathrm{kg})$. World wide, the energy consumption for the production of alumina had dropped from $13 \mathrm{MJ} / \mathrm{kg}$ alumina of 1990 to $12 \mathrm{MJ} / \mathrm{kg}$ of alumina of 2000 [92]. The latest available data show that in 2003 world-wide energy consumption for alumina production was 11,644 mega-joules per tonne of alumina(11.6 MJ/kg). According to survey of the International Aluminum Institute [89], in the 1950's it took on average about $21 \mathrm{kWh}$ (kilowatt-hours) (75.6 MJ/kg) to make a kilogram of aluminum from alumina. By 1999 the newest smelters consumed just $13 \mathrm{kWh}(46.8 \mathrm{MJ} / \mathrm{kg})$, a decrease of nearly $40 \%$. The global average electrical power used in primary aluminum production in 2003 to is 15 $\mathrm{kWh} /$ tonne-Al. More than 55 per cent of the world's primary aluminum is produced using hydro-electric power, which is a carbon-free and renewable source of energy. A recent survey shows that the energy sources of electrical power used in primary aluminum production in 2003 were: hydro-49.2\%; coal-36.1\%; oil-0.5\%; natural gas-9.4\%; and nuclear-4.8\% [92]. 


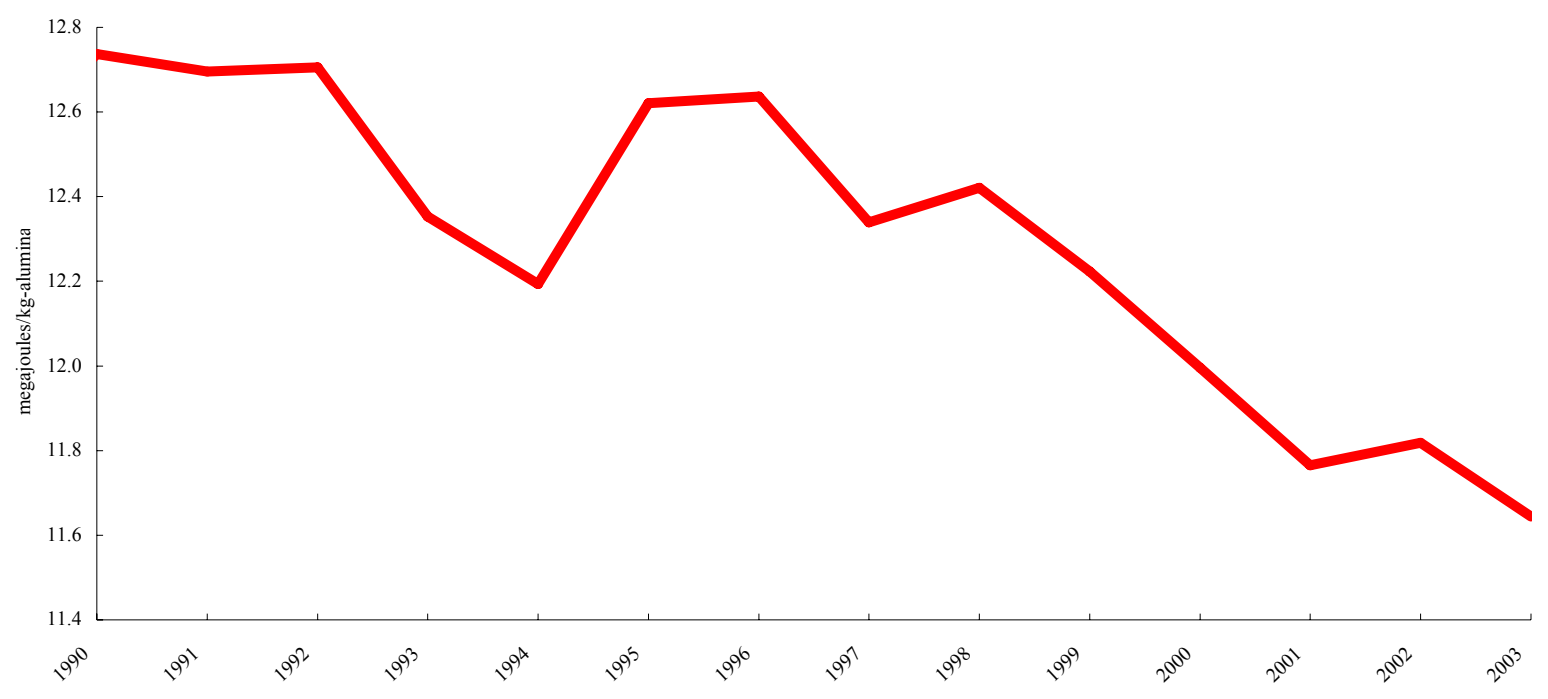

Figure 21. Energy factors for metallurgical alumina production; global average [92].

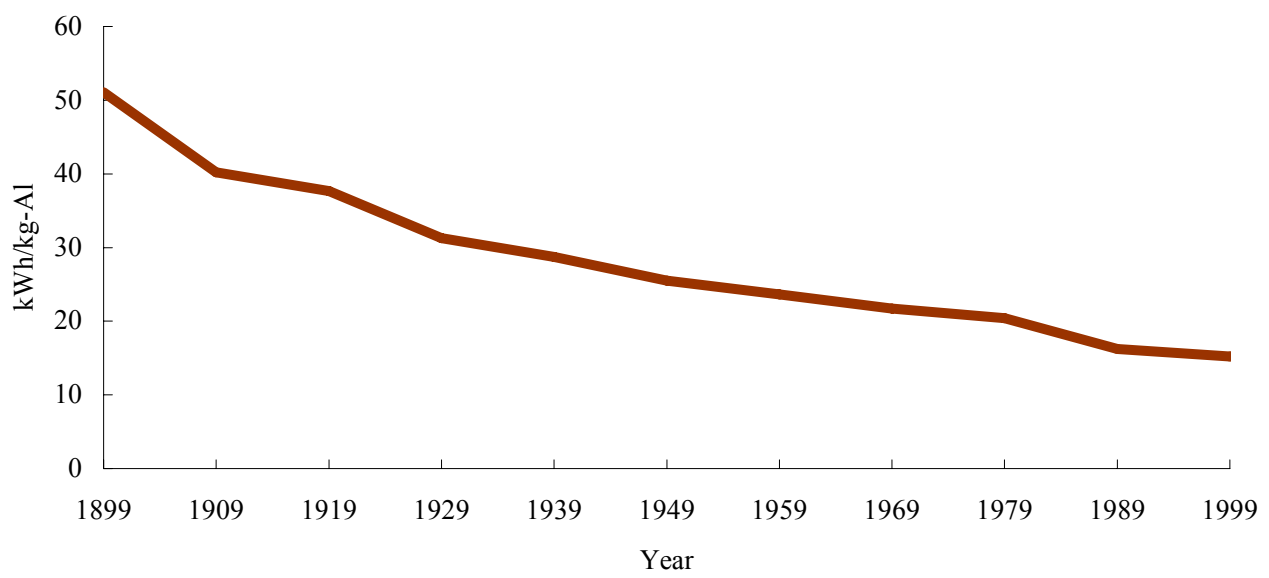

Figure 22. Electricity consumption for primary aluminum production [97]

Perfluorocarbon compounds (PFCs) are major source of emissions in primary aluminum production. As discussed before, these two PFCs are tetrafluoromethane $\left(\mathrm{CF}_{4}\right)$, and hexafluoroethane $\left(\mathrm{C}_{2} \mathrm{~F}_{6}\right)$. The global PFCs emission data are reported in table 27 . 
Table 27 Global average PFC emissions per tonne primary aluminum produced [96]

\begin{tabular}{lllllllllll}
\hline Year & 1990 & 1995 & 1998 & 1999 & 2000 & 2001 & 2002 & 2003 & 2004 & 2010 \\
\hline PFC & 4.42 & $2.60 *$ & 2.72 & 2.42 & 2.19 & 1.54 & 1.53 & 1.26 & 1.16 & $0.88^{* *}$ \\
emissions & & & & & & & & & \\
Note: emission unit in $\mathrm{CO}_{2}$-eq/t-Al; & $*$ estimated; ** projected goal
\end{tabular}

Table 28 Global electric energy consumption in primary aluminum production [97]

\begin{tabular}{|c|c|c|c|c|c|c|c|c|c|c|c|c|c|c|c|c|c|}
\hline Year & 1899 & 1909 & 1919 & 1929 & 1939 & 1949 & 1959 & 1969 & 1979 & 1989 & 1999 & 2000 & 2001 & 2002 & 2003 & 2004 & 2005 \\
\hline Electricity & 51.1 & 40.2 & 37.7 & 31.3 & 28.7 & 25.5 & 23.6 & 21.7 & 20.4 & 16.3 & 15.2 & 15.4 & 15.2 & 15.1 & 15.2 & 15.3 & 15.3 \\
\hline
\end{tabular}

\section{Current Trends and Future Outlook in the Production of Metals}

The most profound trends in the production of metals that reduced the associated emissions relate to adopting new technologies, use of the sulfur content of the ores and adding pollution control equipment.

Adopting new technologies is likely going to continue as old facilities are phased out and new ones are added. Much of the recent technological research and development has focused on improving leaching and metallurgical processes. In primary zinc production, hydrometallurgical separations have substituted smelting in most N.A. facilities. The shift to electrolytic processing drastically reduced cadmium emissions because it eliminated the sintering step in zinc refining, and thus, much of the particulates burden. Also, the early practice of roasting zinc sulfide and discharging the $\mathrm{SO}_{2}$ into the atmosphere was replaced by converting the gas to sulfuric acid.

The same is expected to happen in copper production. The need for refined copper is likely to increase as China and India are increasing their consumption. Implementation of the SX-EW process is gaining momentum, and this has economic advantages as it allows for the economic processing of low-grade material. In one case, Phelps Dodge Morenci, the entire operation has been converted to a leaching facility. Industry representatives predict that the industry is only a 
few years away from widespread hydrometallurgical treatment of copper-iron sulfide ores [93] (likely through bacteriological leaching [94]) and copper concentrates (through reacting in a high temperature pressure vessel). In both cases, refined copper could be produced without the need for smelting and refining. There is at least one mine, in Chile, which is economically leaching copper-iron sulfide ores, reportedly with a native bacterial organism.

On the other hand, the energy factors in the mining industry have been increased moderately because less concentrated ores are being processed, and because the more environmentally friendly electrolytic production, often uses more energy than the pyrometalurgical processes it replaces.

In this article, we only covered primary metal production starting from the mining of the metalcarrying ores. For the base metals, especially aluminum and copper there is a substantial secondary production through recycling of used products. Secondary metal production generates much lower emissions and requires less energy than primary production. Copper from ore requires five to seven times more energy than that required for processing recycled metal and this ratio rises with decreasing ore grade. Aluminum from ore uses approximately twenty times more energy than from recycled metal $[65,94]$.

\section{Discussion/Conclusion}

Fundamentally this report is a small part of the entire life cycle analysis of the CIGS photovoltaic cell. From this report, information is gathered about the various methods of extracting minor metals, as well as some of the emissions and required materials needed for extraction. This initial step is where some of the environmental effects from photovoltaic cells occur. The other two steps are during production and disposal. 
In the "cradle" section of the life cycle analysis of CIGS photovoltaic cells, indium, gallium and selenium are mined as by-products of major metals. Some of these processes of extraction have been used for many decades, while other are still novel. As technology improves, additional methods of extraction will be developed and applied. At this point, these metals are extracted through roasting, leaching, or electrolysis. Then the purification is performed through more electrolysis, vacuum distillation, or crystallization (see Table 3).

From this report, the extraction of indium, gallium and selenium were from raw sources, but these metals are also recovered from recycled material. This could be an area for further studies. Also the energy intensity of each production method will be assessed.

\section{References}

1. Nriagu, J. O. and J. M. Pacyna (1988). Quantitative assessment of worldwide contamination of the air, water and soils with trace metals. Nature (London), 333: 134-139, 1988.

2. Skeaff and Dureuil, 1997

3. Pacyna J. and Pacyna E., An assessment of global and regional emissions of trace metals to the atmosphere from anthropogenic sources worldwide, Environ. Rev.; 9:269-98, 2001

4. Frischknecht R. Allocation in life cycle inventory analysis for joint production. Int. J. LCA 2000; 5(2):1-11.

5. Environmental management-life cycle assessment. Goal and scope definition and inventory analysis, ISO 14041, International Organization for Standardization, Geneva, Switzerland.

6. Ayres R U, Ayres L W. Industrial Ecology, Edward Elagra, 1996

7. Weidema B, Norris G. Avoiding co-product allocation in the metals sector. Presentation for the ICMM International Workshop on Life Cycle Assessment and Materials 2002.

8. DOE, 2002

9. US EPA, Compilation of Air Pollutant Emission Factors, AP-42, $5^{\text {th }}$ ed., Vol. I: Stationary Point and Area Sources, Chapter 12: Metallurgy Industry; 1995. http://www.epa.gov/ttn/chief/ap42/;

10. US EPA, Compilation of Air Pollutant Emission Factors, AP-42, Section 12.3, Primary Copper Smelting, 1995. Pacific Environmental Services, Research Triangle Park, NC.

11. Fthenakis V.M., Life cycle impact analysis of cadmium in CdTe PV production, Renewable and Sustainable Energy Reviews, 8, 303-334, 2004.

12. Andersson B. Materials availability for large-scale thin-film photovoltaics. Progress in Photovoltaics 2000; 8:61-76 
13. Norgate, T. E. \& Rankin, W. J., 'An Environmental Assessment of Lead and Zinc Production Processes', Proceedings, Green Processing 2002, International Conference on the Sustainable Processing of Minerals, May 2002, pp 177-184

14. Description of Cominco Trail Operations/Emissions, April 2001. http://www.teck.com/environment/articles.htm

15. Liewellyn T. Cadmium (material flow). Bureau of Mines Information Circular 1994, US Department of the Interior

16. Chagnon, M. J., "Indium and Indium Compounds," Kirk-Othmer Encyclopedia of Chemical Technology, 4th ed., 2000.

17. Indium Statistics and Information, 2004, US Geological Survey, http://minerals.usgs.gov/minerals/pubs/commodity/indium/indiumcs04.pdf

18. Felix, Noel, "Indium and Indium Compounds," Ullmann's Encyclopedia of Industrial Chemistry, Hoboken, Belgium: $6^{\text {th }}$ ed. 2002.

19. Kidd Creek Zinc Plant, from Falconbridge Limited website: http://www.falconbridge.com/

20. Moskalyk R.R., Review of germanium processing worldwide, Minerals Engineering, 17 393-3402, 2004

21. Germanium, 2002 J.D. Jorgenson with assistance from C.F. Crews, US Geological Survey Minerals Yearbook, pp. 32.1-32.6, http://minerals.usgs.gov/minerals/pubs/commodity/germanium/germmyb02.pdf

22. Germanium, 2003, US Geological Survey http://minerals.usgs.gov/minerals/pubs/commodity/germanium/220303.pdf

23. Kramer, Deborah. "Gallium” Email to the author. 16 June 2003

24. Ogebuoboh F, Asarco, communication with Fthenakis V., Feb. 5, 2002

25. Redden R, Bult R, Bollong A. The Purification of $\mathrm{Cd}$ and Te by zone refining. Paper No. A86-60, The Metallurgical Society of American Institute of Mining, Metallurgical and Petroleum Engineers (AIME), Warrendale, PA, 1986.

26. Kovalevsky S, Shelpakova I. High purity zinc, cadmium, tellurium, indium and gallium: Preparation and analysis. Chemistry for Sustainable Development 2000; 8:85-87.

27. Chulzhanov Y, Nenashev B, Popov S, Chulzhanova M. Preparation of high-purity chalcogens. Chemistry for Sustainable Development 2000; 8:29-31.

28. Hirsch H, Liang S, White A. Preparation of high-purity cadmium, mercury, and tellurium. Semiconductors and Semimetals; 18: 23.

29. Prasad D, Sudheer C, Munirathnam N, Prakash T. Tellurium purification: Various techniques and limitations. Bull Mater. Sci 2002; 25(6):545-547.

30. Base Metal and Iron Ore Mining. Pollution Prevention and Abatement Handbook. World Bank Group, 1998

31. US EPA. Compilation of air pollutant emission factors. AP-42, Section 12.18; LeadBearing Ore Crushing and Grinding, 1995.

32. The RCRA, the Resource Conservation and Recovery Act, characterizes what constitutes hazardous waste by either listing or leaching tests.

33. Berdowski J, van der Most P, Veldt C, Bloos J. Emissions Inventory Guidebook, Activity 030304, Primary Lead Production, November 1995, Inspectorate for the Environment, Dept. for Monitoring and Information Management, Den Haag, The Netherlands.

34. Pacyna J. Survey on heavy metal sources and their emission factors for the ECE countries. ECE Convention on Long-range Transboundary Air Pollution Working Group on Technology. Prague, 15-17 October 1991, 1990. p. 27-55. 
35. Berdowski J, van der Most P, Veldt C, Bloos J. Emissions Inventory Guidebook, Activity 030305, Primary Zinc Production, February 2003, Inspectorate for the Environment, Dept. for Monitoring and Information Management, Den Haag, The Netherlands

36. Teck Cominco Ltd: http://www.teck.com/operations/trail/index.htm

37. Trail and Sustainability-A Review of 2003, Teck Cominco. Website: http://www.teckcominco.com/operations/trail/sustainability.htm

38. Teck Cominco Trail Operations/Emissions; April 2001. http://www.teck.com/environment/articles.htm.

39. Robert U. Ayres, Leslie W. Ayres and Ingrid Råde, The Life Cycle of Copper, Its CoProducts and By-Products, Mining, Minerals and Sustainable Development, January 2002, No. 24.

40. Recycling Metal, United States Geological Survey, http://minerals.er.usgs.gov/minerals/pubs/commodity/recycle/recymyb01.pdf

41. Copper Statistics and Information, United States Geological Survey, http://minerals.er.usgs.gov/minerals/pubs/commodity/copper/

42. Environmental Release Report: Kennecott Utah Copper Smelter \& Refy, 2002 TRI Pollution Releases, Scorecard, http://www.scorecard.org/env-releases/facility.tcl?tri_id=84006KNNCT8362W

43. Jeanette B. Berry, Juan J. Ferrada, Ph.D., L. R. Dole, Ph.D., and Moonis Ally, Ph.D. Oak Ridge National Laboratory, Sustainable Recovery Of By-Products In The Mining Industry

44. R.R. Moskalyk, A. M. Alfantazi, Review of copper pyrometallurgical practice: today and tomorrow, Minerals Engineering 16 (2003) 893-919

45. Energy and Environmental Profile of the U.S. Mining Industry: 5 Copper

46. Description of Kidd Metallurgical Division of Noranda, Noranda's website: http://www.noranda.com

47. C. J. Newman, D. N. Collins, and A. J. Weddick, Kennecott Utah Copper Corporation, Technical Report-"Recent operation and environmental control in the Kennecott Smelter", http://www.kennecott.com/library reports rpt6.htm

48. Our Business, Copper-Collahuasi, SX-EW Plant Flow-sheet, Falconbridge Limited's website: http://www.falconbridge.ca

49. Phelps Dodge Mining Co., website: http://www.phelpsdodge.com/AboutUs/OurCompanies/Mining/Mining.htm

50. John D. Jorgenson, U.S. Geological Survey, Mineral Commodity Summaries, Selenium and Tellurium-2002, http://minerals.usgs.gov/minerals/pubs/commodity/selenium/selemyb02.pdf

51. U.S. Geological Survey, Mineral Commodity Summaries, January 2004, Selenium, http://minerals.usgs.gov/minerals/pubs/commodity/selenium/830303.pdf

52. Hoffmann, J. E. and Reimers, Jan "Selenium and Selenium Compounds," Kirk-Othmer Encyclopedia of Chemical Technology, 4th ed., 2000.

53. Langner, Bernd E. "Selenium and Selenium Compounds," in Ullmann's Encyclopedia of Industrial Chemistry, Hoboken, Belgium: $6^{\text {th }}$ ed. 2002.

54. Roth, David. "Powder Metals," Penn State Erie, The Behrend College.

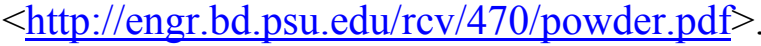


55. Marja Riekkola-Vanhanen, Finnish expert report on best available techniques in copper production and by-production of precious metals, The Finnish Environment 316, HELSINKI 1999

56. "Selenium," U.S. Environmental Protection Agency. 6 Aug. 2003 $<$ http://www.epa.gov/epaoswer/other/mining/minedock/id/id4-sel.pdf >.

57. Roskill. The economics of tellurium 1982, $3^{\text {rd }}$ edition, Roskill Information Services, London, 1982, cited in Andersson, 2000.

58. Hoffmann J, Reimers J, King M. Tellurium and Tellurium Compounds. Kirk-Othmer Encyclopedia of Chemical Technology 2001.

59. Knockhaert G, Tellurium and tellurium compounds. Ullmann's Encyclopedia of Industrial Chemistry 2000.

60. USGS's 2005 report on tellurium

61. Kennecott Utah Copper Corporation, website: http://www.kennecott.com/copper_how_produce.html

62. Michael J. Magyar, Molybdenum, U.S. Geological Survey 2003 Year Book; http://minerals.usgs.gov/minerals/pubs/commodity/molybdenum/molybmyb03.pdf

63. Stigliani W, Anderberg S. Chapter 7 In: Ayres R, Simonis U, editors. Industrial metabolism. The United Nations University, 1994.

64. Jozef M. Pacyna et al., Emission Inventory Guidebook, February, 2003, B336. http://reports.eea.eu.int/EMEPCORINAIR3/en/B336vs2.2.pdf

65. Hodges C. A., Mineral resources, Environmental Issues, and Land Use, Science, vol. 268, pp. 1305-1312, 1995

66. Olympic Dam' copper and uranium business, website: http://www.wmc.com/about/ourbusiness/copper.htm

67. Social \& Environmental Report - 2003, Kennecott Utah Copper Corporation, http://www.kennecott.com/env report 2003/

68. Ludvigsson B. M. Larson S. R., Anode Slimes Treatment, JOM, 2003

69. "NORANDA INC. \& FALCONBRIDGE LIMITED 2003 ACTION PLAN", Submitted to Canada's Climate Change Voluntary Challenge \& Registry Inc., 31 October 2003.

70. "Final Report: Multi-pollutant Emission Reduction Analysis Foundation (MERAF) for the Base Metals Smelting Sector" Prepared by: Minerals And Metals Division National Office Of Pollution Prevention Environment Canada, September 17, 2002.

71. EPA Office of Compliance Sector Notebook Project: Profile of the Nonferrous Metals Industry, SIC Codes 333-334, September 1995. Pp.22-29

http://www.epa.gov/Compliance/resources/publications/assistance/sectors/notebooks/nfm etlsn.pdf

72. Sergio Alvaradoa, Pedro Maldonadob, Iva'n Jaquesb, Energy and environmental implications of copper production, Energy 24 (1999) 307-316.

73. S. Alvarado a, P. Maldonado b, A. Barrios b, I. Jaques, Long term energy-related environmental issues of copper production, Energy 27 (2002) 183-196

74. Bruch, H., D. Gohlke, C. Kruger, M. Reuter, I. V. Roepenack, E. Rombach, G. Rombach and P. Winkler, LCI of copper production and processing, special printing (s198), German Copper Institute (DKI), Duesseldorf, Germany, 1995

75. Karen S. Yoshiki-Gravelsins, James M. Toguri, and Roland T.C. Choo, Metal Production, Energy, and the Environmental, Part I- Energy Consumption, JOM, May, 1520, 1993 
76. Norgate, T. E. \& Rankin, W. J., 'Life Cycle Assessment of Copper and Nickel Production', Proceedings, Minprex 2000, International Conference on Minerals Processing and Extractive Metallurgy, September 2000, pp133-138.

77. Chapman P.F. and Roberts F., Metal Resources and Energy, Butterworths, 1983

78. Michael J. Magyar, Molybdenum, US Geological Survey, 2003 http://minerals.usgs.gov/minerals/pubs/commodity/molybdenum/molybmyb03.pdf

79. Mineral Commodity Summaries-Aluminum, 2005, United States Geological Survey, website: http://minerals.usgs.gov/minerals/pubs/commodity/aluminum/alumimcs05.pdf

80. Downs, A, ed., Chemistry of Aluminum, Gallium, Indium and Thallium. New York: 1993, pp. 81-109.

81. "Aughinish Alumina: Bayer Process" 19 Jun. 2003 $<$ http://www.aughinish.com/bayer.htm>.

82. P.R. Moskalyk, Gallium: the backbone of the electronics industry, Minerals Engineering, 16 (2003) $921-929$

83. Kramer, Deborah. "Gallium" Email to the author. 16 June 2003.

84. Beja, Maurice. "Method of Extracting Gallium Oxide from Aluminous Substances," U.S. Patent 2574 008, Dec. 20, 1947.

85. Greber, Jörg Friedrich “Gallium and Gallium Compounds," Ullmann's Encyclopedia of Industrial Chemistry, Hoboken, Belgium: $6^{\text {th }}$ ed. 2002.

86. De la Breteque, Pierre. "Method of Recovering Gallium from an Alkali Aluminate Lye," U.S. Patent 2793 179, June 11, 1956.

87. Chartroux, Christine, et al. "Preorganized Complexing Agents as a Tool for Selective Solvent Extraction Processes." Industrial \& Engineering Chemistry Research. 39 (2000): 3616-3624. http://www.chm.tudresden.de/anorg/gloe/Forschung/For\%20example-Dateien/example\%20I.pdf

88. Hutter, Jean-Claude and Andre Peyron "Purification of Gallium by Halogenation and Electrolysis," U.S. Patent 3075 901, June 4, 1959.

89. Smelter Emissions, International Aluminum Institute's website, http://www.worldaluminium.org/environment/challenges/emissions.html

90. Alcoa 2003 Sustainability Report, Regional Sustainability Reports- Alcoa Australia, http://www.alcoa.com/australia/en/pdf/Community/alcoa 2003 sustainability.pdf

91. Alcoa 2003 Sustainability Report, Regional Sustainability Reports-Alcoa Canada Primary Metals, $h$ ttp://www.alcoa.com/canada/en/pdf/Alcoa_LifeMagazine_2003.pdf

92. The Aluminium Industry's Sustainable Development Report, International Aluminum Institute's website: http://www.worldaluminium.org/iai/publications/documents/sustainable_summary.pdf

93. United States International Trade Commission, Industry Trade and Technology ReviewRefined Copper Industry, USITC publication 3574, December 2002, Pp.18. http://hotdocs.usitc.gov/docs/pubs/industry trade technology review/pub3574.pdf

94. Idaho National Engineering and Environmental Laboratory, Biohydrometallurgy Research and Development at the Idaho National Engineering and Environmental Laboratory, http://www.inl.gov/factsheets/industrial/biohydrometallurgy.pdf

95. Wernick I. and Themelis N.J., Recycling Metals for the Environment, Annual Reviews Energy and Environment, 23, 465-97, 1998

96. International Aluminum Institute, The International Aluminum Institute Report On The Aluminum Industry's Global Perfluorocarbon Gas Emissions Reduction Program Results 
Of The 2004 Anode Effect Survey, International Aluminum Institute's website:http://www.world-aluminium.org/iai/publications/documents/pfc2004.pdf

97. International Aluminum Institute, Electrical Power Used in Primary Aluminum Production, http://www.worldaluminium.org/iai/stats/historical.asp?currentYear $=2007 \&$ material $=1 \&$ formType $=4 \&$ dat aType $=26 \&$ period $=4 \&$ fromYear $=1980 \&$ fromMonth $=1 \&$ to Year $=\&$ toMonth $=1 \&$ area $=\& \mathrm{~s}$ ubmitSearch $=$ Find + Stats

98. United States Geological Survey, Gallium Statistics and Information, http://minerals.usgs.gov/minerals/pubs/commodity/gallium/index.html\#mcs

99. Jozef M Pacyna, Primary Copper Production, Emission Inventory Guide Book, Snap Code: 030306, B336-4, December 2006, 


\section{APPENDIX}

Summary Tables

Emissions per MT of metals produced: $\mathrm{Zn}-\mathrm{Pb}, \mathrm{Zn}-\mathrm{Cu}$, (electrolytic) Smelters

\begin{tabular}{|c|c|c|c|c|}
\hline 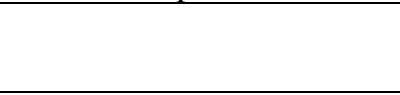 & $\begin{array}{c}\text { Teck cominco, Canada } \\
(00-04, \text { Table } 3)\end{array}$ & $\begin{array}{c}\text { Falconbridge, Canada } \\
(97-01, \text { Table 4) }\end{array}$ & Commercial database & Details \\
\hline Major products & $\mathrm{Zn}(80 \%), \mathrm{Pb}(20 \%)$ & $\mathrm{Zn}(52 \%), \mathrm{Cu}(48 \%)$ & & \\
\hline Byproducts & $\begin{array}{l}\text { In, Ge, Cd, } \mathrm{Au}, \mathrm{Ag} \text {, } \\
\text { Fertilizer }\end{array}$ & $\mathrm{Cd}, \mathrm{In}, \mathrm{H} 2 \mathrm{SO} 4$ & & \\
\hline Energy $(\mathrm{GJ} / \mathrm{t})$ & $39-46$ (primary) & $23.8-26.4$ (mixed) & $\begin{array}{c}41.9(\mathrm{E}), 84.5(\mathrm{~T}) \\
\text { (primary) }\end{array}$ & \\
\hline $\mathrm{SO} 2(\mathrm{~kg} / \mathrm{t})$ & $\mathrm{N} / \mathrm{A}$ & $14.3-21$ & $25(\mathrm{E}), 30.4(\mathrm{~T})$ & \\
\hline $\begin{array}{l}\mathrm{Heavy} \text { metal, air }(\mathrm{g} / \mathrm{t}) \\
\mathrm{Cd} \\
\mathrm{Cu} \\
\mathrm{Pb} \\
\mathrm{Zn}\end{array}$ & $\begin{array}{c}0.07-0.2 \\
5.4-18.9 \\
12 \\
\end{array}$ & $\begin{array}{c}1.9 \\
228 \\
112 \\
112-136 \\
\end{array}$ & $\begin{array}{l}0.05(\mathrm{E}), 50.1(\mathrm{~T}) \\
0.43(\mathrm{E}), 2.69(\mathrm{~T}) \\
625(\mathrm{E}), 1850(\mathrm{~T}) \\
820(\mathrm{E}), 10000(\mathrm{~T})\end{array}$ & $\begin{array}{l}\text { For other heavy metal } \\
\text { emissions, see Tables } 3 \\
\text { and } 4 .\end{array}$ \\
\hline $\begin{array}{l}\text { Heavy metal, water }(\mathrm{g} / \mathrm{t}) \\
\mathrm{Cd} \\
\mathrm{Cu} \\
\mathrm{Pb} \\
\mathrm{Zn}\end{array}$ & $\begin{array}{c}0.4-0.8 \\
\\
4.3-7.7 \\
59-85 \\
\end{array}$ & $\begin{array}{c}0.19-0.77 \\
1.5-4.6 \\
0.24-0.61 \\
11.2-102.1 \\
\end{array}$ & $\begin{array}{c}4.2(\mathrm{E}), 0.18(\mathrm{~T}) \\
7.9(\mathrm{E}), 13.6(\mathrm{~T}) \\
46.2(\mathrm{E}), 15.3(\mathrm{~T}) \\
57.8(\mathrm{E}), 28.2(\mathrm{~T})\end{array}$ & $\begin{array}{l}\text { For other heavy metal } \\
\text { emissions, see Tables } 3 \\
\text { and } 4 .\end{array}$ \\
\hline $\mathrm{CO} 2(\mathrm{t} / \mathrm{t})$ & $0.85-0.96$ & $1.2-1.4$ & $1.83(\mathrm{E}), 4.96(\mathrm{~T})$ & \\
\hline
\end{tabular}

E: Ecoinvent, $80 \%$ hydro-, 20\% pyro-metallurigical, year not specified. Zinc for coating, Western Europe.

T: ETH, based on 1979 data, including mining stage. Outdated. 
Emissions per MT of metals produced: $\mathrm{Cu}$ smelters

\begin{tabular}{|c|c|c|c|c|c|c|c|}
\hline & \multicolumn{3}{|c|}{ Flash smelter } & \multicolumn{2}{|c|}{ Bath smelter } & \multirow{2}{*}{\begin{tabular}{l}
\multicolumn{1}{c}{ Electrolytic } \\
CCR, Canada \\
$(97-03$, Table 15)
\end{tabular}} & \multirow{2}{*}{\begin{tabular}{l}
\multicolumn{1}{c}{ Ecoinvent } \\
North American \\
avg. \\
Revervatory \\
furnace- $23.3 \%$, \\
Flash smeling- \\
$53.9 \%$, SX-EW- \\
$17.6 \%$
\end{tabular}} \\
\hline & $\begin{array}{l}\text { KUCC, US } \\
(98-01, \\
\text { Tables } 9 \text { and } \\
10)\end{array}$ & $\begin{array}{l}\text { Olympic } \\
\text { dam, } \\
\text { Australia } \\
\text { (99-03, Table } \\
\text { 9) }\end{array}$ & $\begin{array}{l}\text { Boliden, } \\
\text { Sweden (00- } \\
02, \text { Table 12) }\end{array}$ & $\begin{array}{l}\text { Horne, } \\
\text { Canada (97- } \\
02, \text { Table 13) }\end{array}$ & $\begin{array}{l}\text { Noranda/Falco } \\
\text { nbridge, } \\
\text { Canada (00-03, } \\
\text { Table 14) }\end{array}$ & & \\
\hline Major products & $\mathrm{Cu}$ & $\mathrm{Cu}$ & $\begin{array}{l}\mathrm{Cu}(90 \%), \mathrm{Pb} \\
(10 \%)\end{array}$ & $\mathrm{Cu}$ & $\begin{array}{l}\mathrm{Cu}(38 \%), \mathrm{Zn} \\
(30 \%), \\
\text { Recycled metal } \\
(11 \%)\end{array}$ & $\mathrm{Cu}$ & \\
\hline Byproducts & Mo $(2-3 \%)$ & $\begin{array}{l}\mathrm{U} 3 \mathrm{O} 8, \mathrm{Au}, \\
\mathrm{Ag}\end{array}$ & & & $\mathrm{Ni}, \mathrm{Co}, \mathrm{Pb}, \mathrm{Al}$ & $\mathrm{Au}, \mathrm{Ag}, \mathrm{Se}, \mathrm{Te}$ & \\
\hline Energy $(\mathrm{GJ} / \mathrm{t})$ & 75.4 & $19.3-25$ & $14.2-20.8$ & $13.4-18.2$ & $20.6-22.7$ & $6.5-8.4$ & 43.6 (Primary) \\
\hline $\mathrm{SO} 2(\mathrm{~kg} / \mathrm{t})$ & $2.0-3.8$ & $15.0-19.1$ & 15 & $490-740$ & $110-170$ & $1-1.3$ & 330 \\
\hline $\begin{array}{l}\text { Heavy metal, air } \\
(\mathrm{g} / \mathrm{t}) \\
\mathrm{Cu} \\
\mathrm{Cd} \\
\mathrm{Pb} \\
\mathrm{Zn}\end{array}$ & $\begin{array}{c}68.4-141 \\
0.3-2.9 \\
5.1-105 \\
1.2-17.1 \\
\end{array}$ & & $\begin{array}{l}5.4 \\
0.25 \\
13.6 \\
21.4 \\
\end{array}$ & & & & $\begin{array}{c}208 \\
5.5 \\
126 \\
128 \\
\end{array}$ \\
\hline GHG (kg/t) & & & & & $4.7-5.4$ & & 2.13 \\
\hline
\end{tabular}

